\title{
Effects of nitrogen and water on growth, photosynthesis, and leaf properties of deciduous tree species with consequences for gypsy moth herbivory
}

Teri S. Myers

West Virginia University

Follow this and additional works at: https://researchrepository.wvu.edu/etd

\section{Recommended Citation}

Myers, Teri S., "Effects of nitrogen and water on growth, photosynthesis, and leaf properties of deciduous tree species with consequences for gypsy moth herbivory" (2000). Graduate Theses, Dissertations, and Problem Reports. 1219.

https://researchrepository.wvu.edu/etd/1219

This Dissertation is protected by copyright and/or related rights. It has been brought to you by the The Research Repository @ WVU with permission from the rights-holder(s). You are free to use this Dissertation in any way that is permitted by the copyright and related rights legislation that applies to your use. For other uses you must obtain permission from the rights-holder(s) directly, unless additional rights are indicated by a Creative Commons license in the record and/ or on the work itself. This Dissertation has been accepted for inclusion in WVU Graduate Theses, Dissertations, and Problem Reports collection by an authorized administrator of The Research Repository @ WVU.

For more information, please contact researchrepository@mail.wvu.edu. 
Effects of nitrogen and water on growth, photosynthesis, and leaf properties of deciduous tree species with consequences for gypsy moth herbivory

\title{
Teri S. Myers
}

\author{
Dissertation submitted to the \\ Eberly College of Arts and Sciences \\ at West Virginia University \\ in partial fulfillment of the requirements \\ for the degree of
}
Doctor of Philosophy
in
Biology

\author{
Richard Thomas, Ph.D., Chair \\ Jonathan Cumming, Ph.D. \\ James McGraw, Ph.D. \\ Rose-Marie Muzika, Ph.D. \\ William Peterjohn, Ph.D.
}

Department of Biology
Morgantown, West Virginia
2000

Keywords: nitrogen, water, deciduous tree growth, photosynthesis, Lymantria dispar Copyright 2000 Teri S. Myers 


\title{
ABSTRACT \\ Effects of nitrogen and water on growth, photosynthesis, and leaf properties of deciduous tree species with consequences for gypsy moth herbivory
}

\author{
Teri S. Myers
}

This study addressed the hypothesis that plants exposed to elevated $\mathrm{N}$ availability are more susceptible to drought and insect herbivory. I grew seedlings of gray birch (Betula populifolia), yellow birch (B. alleghaniensis), and red oak (Quercus rubra) for two years under varying levels of $\mathrm{N}$ and water availability in the field. Growth and biomass allocation were examined for the three species. Photosynthetic response was determined and feeding trials with gypsy moth larvae were conducted with both birch species. I found that the effects of nitrogen on growth and biomass allocation depended on species, while water had no significant effect on these measures. Both birch species showed increased total biomass, leaf area, and relative growth rate with nitrogen fertilization. Red oak seedlings showed decreased root/shoot ratio and root weight ratio with nitrogen fertilization. These changes could potentially increase transpirational water loss in birch seedlings and reduce water uptake in red oak seedlings, making these species more susceptible to drought. Photosynthetic rate, stomatal conductance, $\mathrm{P}_{\mathrm{WUE}}, \mathrm{P}_{\mathrm{NUE}}$, and photosynthetic capacity of gray birch were greater than yellow birch and these differences were independent of nitrogen and water supply. Gray birch foliage had greater water content, nitrogen concentration, and sugar/condensed tannin ratios than yellow birch. Gray birch also had lower $\mathrm{C} / \mathrm{N}$ ratios and fewer condensed tannins than yellow birch. In this way, gray birch was a more nutritive food source for gypsy moth and larvae had higher growth rates when feeding on it, compared to yellow birch. When gypsy moth larvae were fed foliage from birch seedlings grown under the different nitrogen and water regimes, larval nutritional indices changed in a nonlinear and unpredictable manner. In summary, this study indicates that the interactive effects of water and elevated $\mathrm{N}$ availability on growth and photosynthetic response may impact competitive interactions between species with different life history traits. Furthermore, it is clear that if changes in species composition occur in forests receiving elevated $\mathrm{N}$ deposition and variations in rainfall events, they will impact feeding behavior and, thus, defoliation by generalist insect herbivores, like gypsy moth. 


\section{ACKNOWLEDGEMENTS}

I extend my deepest gratitude to everyone who helped make this project possible. First, to my advisor, Dr. Richard Thomas for his unending support. Special thanks to what I regard as an excellent committee, Dr. Richard Thomas, Dr. Jonathan Cumming, Dr. James McGraw, Dr. Rose-Marie Muzika, and Dr. William Peterjohn. These people were instrumental in the design of this project and I thank all of them for being so helpful whenever I asked for advice. I especially thank Rose-Marie for extending herself to join the committee and for her commitment to attend our meetings once she moved to Missouri. Her encouraging support was invaluable to me.

I thank George Ruckle at the West Virginia University Agronomy Farm for providing the temperature and precipitation data, as well as the experimental site. Thanks to Linda Butler for her discussions about gypsy moth. Thanks also to USDA APHIS at Otis Air Force Base in Massachusetts for supplying gypsy moth larvae. Over the years, I had many assistants at the field site. I would not have been able to conduct this study without them. Great thanks to those assistants that faithfully stuck by my side for the long, hot, and buggy haul: Chris Feathers, Gretchen Schaupp, Gary Vedula, and Terica Wolfe. Thanks to Jamie Huffman and Stacey Waugh for their help in the field and the laboratory. Also, thanks to Clint Springer for collaborating with me to conduct the photosynthesis study and for helping to keep me sane during the final and most difficult year of this study. I thank all of the graduate students, my friends, who have been in the program with me at West Virginia University for their interest in my project and providing me with the encouragement to persevere.

I have the utmost appreciation for my husband, Dr. Todd M. Myers. He inspired me to achieve this goal and together, we did it! I also thank my mother, Lorraine Tamboia, for always encouraging me to be the best that I can be.

I am especially thankful for the several sources that funded this research throughout the years, including an EPSCOR grant and the Earl Core Memorial Scholarship for Ecological Research in Appalachia. 


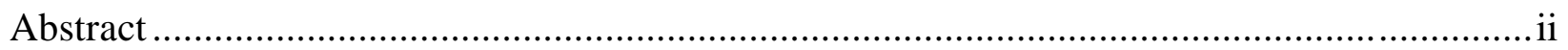

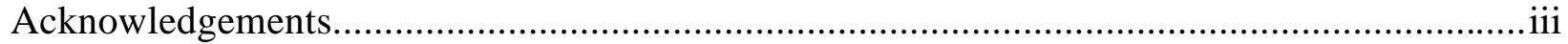

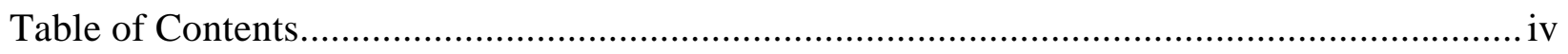

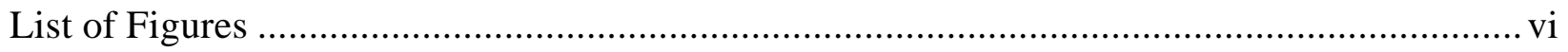

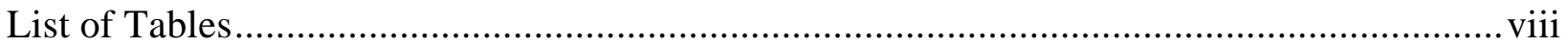

\section{Chapter 1}

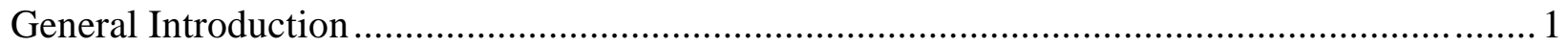

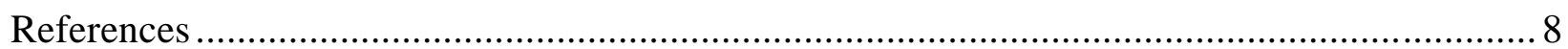

\section{Chapter 2}

Effects of $\mathrm{N}$ and water availability on growth and biomass allocation of three deciduous species

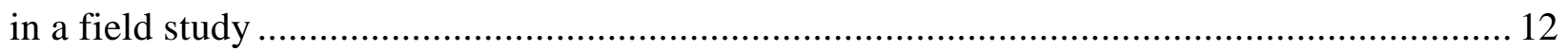

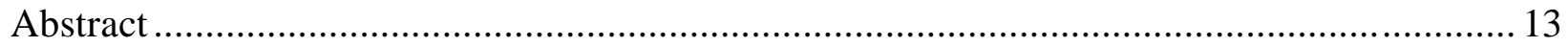

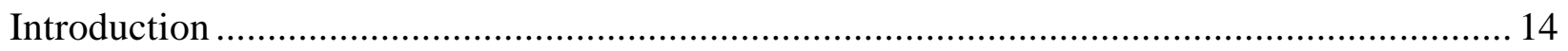

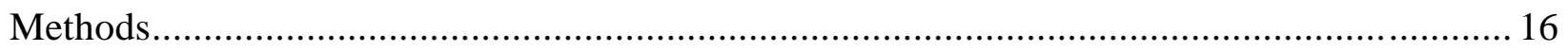

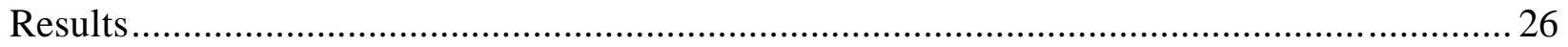

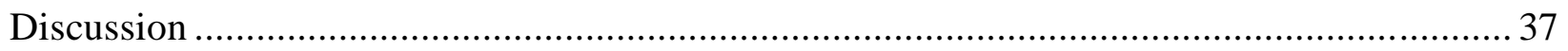

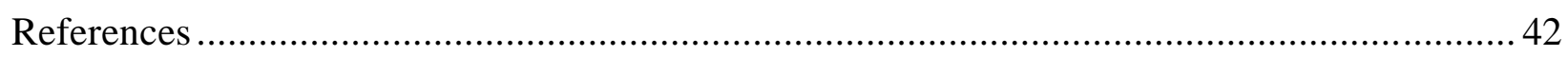

\section{Chapter 3}

The effects of $\mathrm{N}$ and water availability on leaf photosynthesis and photosynthetic resource-use efficiency of two birch species under field conditions .............................................................. 47

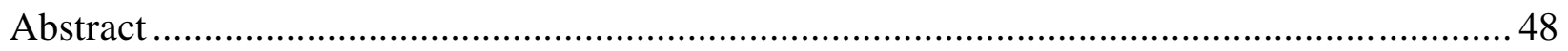

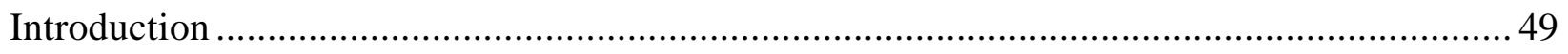

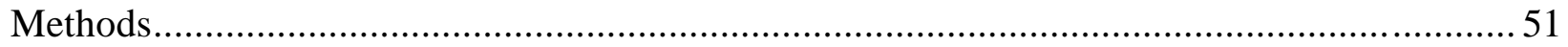

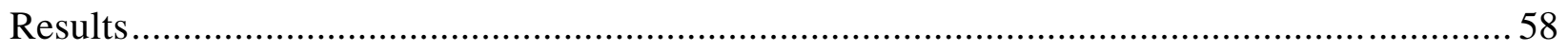

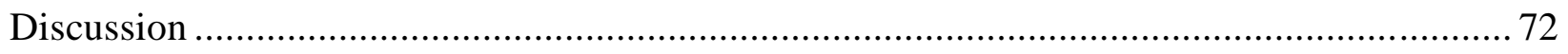




\section{Chapter 4}

Impacts of $\mathrm{N}$ and water availability on seedling foliar chemistry of differently-suitable host

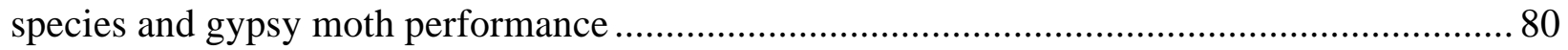

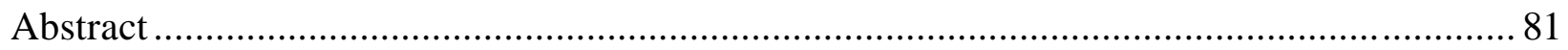

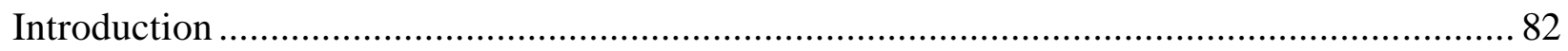

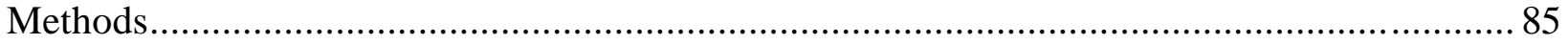

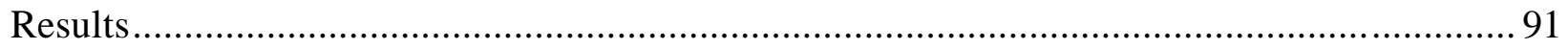

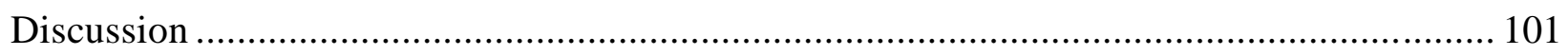

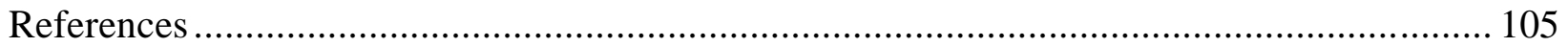

General Discussion ............................................................................................. 111

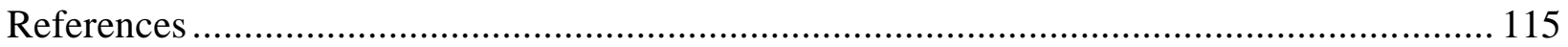

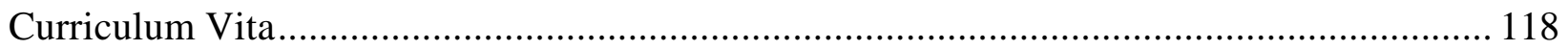




\section{LIST OF FIGURES}

\section{Chapter 1}

Fig. 1.1 Interactive effects of elevated $\mathrm{N}$ deposition and high or low water availability on plant growth, physiology, foliar chemistry, and generalist insect herbivore performance. (+) indicates change in a positive direction, while (-) indicates change in a negative direction. 5

\section{Chapter 2}

Fig. 2.1 Tree seedlings growing in year two at the experimental site under $\mathrm{N}$ and water treatments.

Fig. 2.2. Experimental layout of the three-way split plot design used to manipulate nitrogen and water availability to deciduous tree seedlings in the field. Key features depicted are orientation of $3 \times 2 \mathrm{~m}$ subplots relative to the sloping hillside, position of tree seedlings relative to drainage pipe, and trenches dug to eliminate surface and subsurface nutrient and water flow to $3 \mathrm{~m}$ between nitrogen treatments and around the perimeter of the experimental area. Nitrogen and water treatments are labeled within each subplot.

Fig. 2.3. Percent soil moisture and weekly precipitation for 1998 and 1999 growing seasons. Soil moisture was measured with TDR at a constant depth of $15 \mathrm{~cm}$ probes. Rainfall was measured using a rain gauge at the WVU Agronomy Farm. The $\mathrm{x}$-axis is labeled by month, from June through October.

Fig. 2.4. Total biomass production of gray birch, yellow birch, and red oak seedlings grown with varying $\mathrm{N}$ and water availability. Standard error bars show $1 \mathrm{SE}+/$ - treatment means. Open bars are reduced water availability, hatched bars are ambient water availability, and closed bars are augmented water availability.

Fig. 2.5. Biomass partitioning of gray birch, yellow birch, and red oak seedlings grown with varying $\mathrm{N}$ and reduced (RED), ambient (AMB), or augmented (AUG) water treatments. Leaf weight ratios (LWR) are light gray, stem weight ratios (SWR) are medium gray, and root weight ratios $(\mathrm{RWR})$ are dark gray.

Fig. 2.6. Relative growth rate of gray birch, yellow birch, and red oak seedlings grown with varying $\mathrm{N}$ and water availability. Standard error bars show $1 \mathrm{SE}+/$ - treatment means. Open bars are reduced water availability, hatched bars are ambient water availability, and closed bars are augmented water availability. 


\section{Chapter 3}

Fig. 3.1. Percent soil moisture and weekly precipitation for 1998 and 1999 growing seasons. Soil moisture was measured with TDR at a constant depth of $15 \mathrm{~cm}$ probes. Rainfall was measured using a rain gauge at the WVU Agronomy Farm. The X-axis is labeled by month, from June through October. The arrow marks the starting date when photosynthetic response was measured.

Fig. 3.2. Net photosynthetic rate $\left(\mathrm{A}_{\text {net }}\right)$ and stomatal conductance $\left(\mathrm{g}_{\mathrm{s}}\right)$ of gray and yellow birch seedlings grown under varying levels of $\mathrm{N}$ and water supply. Standard error bars show $1 \mathrm{SE} \pm$ treatment means. Open bars are reduced water treatment, hatched bars are ambient water treatment, and closed bars are augmented water treatment.

Fig. 3.3. Representative A- $\mathrm{C}_{\mathrm{i}}$ curves of gray and yellow birch seedlings grown under varying levels of $\mathrm{N}$ and water supply. Open circles are reduced water treatment. Closed triangles are ambient water treatment. Closed circles are augmented water treatment....

Fig. 3.4. Photosynthetic water use efficiency $\left(\mathrm{P}_{\mathrm{wUE}}\right)$ and phtosynthetic nitrogen use efficiency $\left(\mathrm{P}_{\mathrm{NUE}}\right)$ for gray and yellow birch seedlings grown under varying levels of $\mathrm{N}$ and water supply. Standard error bars show $1 \mathrm{SE} \pm$ treatment means. Open bars are reduced water treatment, hatched bars are ambient water treatment, and closed bars are augmented water treatment.

\section{Chapter 4}

Fig. 4.1. Growth rate and consumption rate of gypsy moth larvae fed gray and yellow birch foliage grown under varying $\mathrm{N}$ and water availability. . Standard error bars show $1 \mathrm{SE} \pm$ treatment means. Open bars are reduced water treatment, hatched bars are ambient water treatment, and closed bars are augmented water treatment $(n=6)$.

Fig. 4.2. Approximate digestibility (AD), efficiency of converting digested food (ECD), and efficiency of converting ingested food (ECI) into larval biomass for gypsy moth larvae fed gray and yellow birch foliage grown under varying $\mathrm{N}$ and water availability. Standard error bars show $1 \mathrm{SE} \pm$ treatment means. Open bars are reduced water treatment, hatched bars are ambient water treatment, and closed bars are augmented water treatment $(n=6)$ 


\section{LIST OF TABLES}

\section{Chapter 2}

Table 2.1. Summary of three-way ANOVAs showing $\mathrm{p}$ values for the effects of species, nitrogen $(\mathrm{N})$, water availability, and their interactive effects on total biomass (TB), root to shoot ratio (R/S), root weight ratio (RWR), stem weight ratio (SWR), leaf weight ratio (LWR), leaf area (LA), leaf mass per unit area (LMA), leaf area ratio (LAR), net assimilation rate (NAR), and relative growth rate $(\mathrm{RGR})$. Statistically significant values $(\mathrm{p}<0.05)$ are in bold, while trends $(0.05<\mathrm{p}<0.10)$ are denoted by $*$.

Table 2.2. Leaf and growth characters of gray birch, yellow birch, and red oak seedlings grown under varying levels of $N$ and water availability. Values are means $( \pm S E), n=3-5$. Leaf and growth characters are leaf area (LA), leaf mass per unit leaf area (LMA), leaf area ratio (LAR), and net assimilation rate (NAR). $\mathrm{N}$ treatments are no $\mathrm{N}$ addition (No), $100 \mathrm{~kg} / \mathrm{ha} / \mathrm{yr} \mathrm{NH}_{4} \mathrm{NO}_{3}$ (100), and $200 \mathrm{~kg} / \mathrm{ha} / \mathrm{yr} \mathrm{NH}_{4} \mathrm{NO}_{3}$ (200). Water treatments are reduced (Red), ambient (Amb), and augmented (Aug).....

\section{Chapter 3}

Table 3.1. $F$ statistics for main treatment effects and their interactions on $\mathrm{A}_{\text {net }}$ (net photosynthesis at growth $\mathrm{CO}_{2}$ ), $\mathrm{g}_{\mathrm{s}}$ (stomatal conductance), $\mathrm{P}_{\mathrm{wUE}}$ (photosynthetic water use efficiency), and $\mathrm{P}_{\mathrm{NUE}}$ (photosynthetic nitrogen use efficiency) of gray and yellow birch seedlings grown under varying $\mathrm{N}$ and water availability. Asterisks refer to the probability of a greater $F$ statistic calculated for the full factorial design: $*=0.01<P \leq 0.05 ; * *=0.001<P \leq 0.01$; *** $P$ $\leq 0.001$.

Table 3.2. $F$ Statistics for main treatment effects and their interactions on $\mathrm{Vc}_{\max }$ (maximum velocity of carboxylation), $\mathrm{J}_{\max }$ (maximum electron transport), the ratio of $\mathrm{J}_{\max }$ to $\mathrm{Vc}_{\max }$, and $\mathrm{A}_{\max }$ (net photosynthetic rate at $\mathrm{CO}_{2}$ saturation) of gray and yellow birch seedlings grown under varying $\mathrm{N}$ and water availability. Asterisks refer to the probability of a greater $F$ statistic calculated for the full factorial design: * $=0.01<P \leq 0.05$; ** $=0.001<P \leq 0.01$; *** $P \leq$ 0.001 .

Table 3.3. $F$ statistics for main treatment effects and their interactions on foliar characters of gray and yellow birch seedlings grown under varying $\mathrm{N}$ and water availability. Asterisks refer to the probability of a greater $F$ statistic calculated for the full factorial design: ${ }^{*}=0.01<P \leq 0.05$; $* *=0.001<P \leq 0.01 ; * * * P \leq 0.001$.

Table 3.4. Leaf characters of gray and yellow birch seedlings grown under varying levels of $\mathrm{N}$ and water availability. Values are means $( \pm \mathrm{SE}), \mathrm{n}=3$. $\mathrm{N}$ treatments are no $\mathrm{N}$ addition (No), $100 \mathrm{~kg} / \mathrm{ha} / \mathrm{yr} \mathrm{N_{4 }} \mathrm{NO}_{3}$ (100), and $200 \mathrm{~kg} / \mathrm{ha} / \mathrm{yr} \mathrm{N_{4 }} \mathrm{NO}_{3}(200)$. Water treatments are reduced (Red), ambient (Amb), and augmented (Aug). 
Table 3.5. Relationships between $A_{\text {net }}$ (net photosynthetic rate) and $g_{s}$ (stomatal conductance), $\mathrm{A}_{\text {net }}$ and leaf $\mathrm{N}$ on an area basis $\left(\mathrm{N}_{\mathrm{A}}\right), \mathrm{Vc}_{\max }$ (maximum rate of carboxylation) and $\mathrm{N}_{\mathrm{A}}, \mathrm{J}_{\max }$ (maximum rate of electron transport) and $\mathrm{N}_{\mathrm{A}}$ for gray and yellow birch seedlings. Species data were pooled across $\mathrm{N}$ and water treatments.

\section{Chapter 4}

Table 4.1. ANOVA results for effects of nitrogen, water availability and tree species on several foliar characteristics, including specific leaf area (SLA), leaf water content (LWC), carbon to nitrogen ratio $(\mathrm{C} / \mathrm{N})$, sugar $(\mathrm{SUG})$, starch (STA), total phenol (TP), condensed tannin $(\mathrm{CT})$, sugar to condensed tannin ratio (SUG/CT), nitrogen concentration $\left(\mathrm{N}_{\mathrm{A}}\right)$, and chlorophyll concentration (CHL). Asterisks refer to the probability of a greater $F$ statistic calculated for the full factorial design: $*=0.01<P \leq 0.05 ; * *=0.001<P \leq 0.01 ; * * * P \leq 0.001$. Error degrees of freedom are 90 for SLA and LWC; 88 for C/N and $\mathrm{N}_{\mathrm{A}} ; 87$ for TP and CT; 37 for SUG, STA, and SUG/CT; 142 for CHL.

Table 4.2. Leaf characters of gray and yellow birch seedlings grown under varying levels of $\mathrm{N}$ and water availability. Values are means $( \pm \mathrm{SE})$. Leaf characters are specific leaf area (SLA), leaf water content (LWC), $\mathrm{C} / \mathrm{N}$ ratio $(\mathrm{C} / \mathrm{N})$, sugar concentration (SUG), starch concentration (STA), total phenol concentration (TP), condensed tannin concentration (CT), sugar/condensed tannin ratio (SUG/CT), nitrogen concentration $\left(\mathrm{N}_{\mathrm{A}}\right)$, and chlorophyll concentration $(\mathrm{CHL})$. N

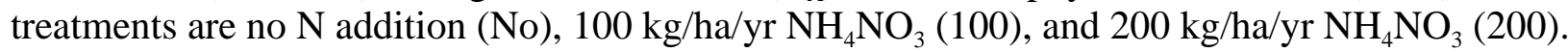
Water treatments are reduced (Red), ambient (Amb), and augmented (Aug).

Table 4.3. ANOVA results for effects of nitrogen, water availability, and tree species on larval growth rate, consumption rate, approximate digestibility (AD), efficiency of converting digested food into larval biomass (ECD), and efficiency of converting ingested food into larval biomass (ECI). Values for ECI and ECD were ln transformed to normalize the distribution of data. Asterisks refer to the probability of a greater $F$ statistic calculated for the full factorial design: * $=0.01<P \leq 0.05 ; * *=0.001<P \leq 0.01 ; * * * P \leq 0.001$. Error degrees of freedom are 193 for growth rate, 103 for consumption rate, 134 for $\mathrm{AD}, 112$ for $\mathrm{ECD}$, and 155 for ECI. For the Plant $\left(\mathrm{N} \mathrm{x} \mathrm{H}_{2} \mathrm{O} \times \mathrm{Sp}\right)$ effect, n.s. indicates that the nested effect was not significant $(\mathrm{p}<0.05)$ and it was excluded from the model during analysis of those parameters. 


\section{Chapter 1}

\section{General Introduction}

Anthropogenic $\mathrm{N}$ inputs on land, including those from fossil fuel burning, $\mathrm{N}$ fertilizer, and the planting of leguminous crop species, slightly exceeds natural N inputs (Galloway 1995). The amount of $\mathrm{N}$ deposited to a region is directly related to its distance from the pollution source and, in North America and Europe, high inputs often occur in forested regions (Ollinger et al. 1993; Vitousek et al. 1997; Aber et al. 1998; Fenn et al. 1998; Erelli et al. 1998). The effects of elevated $\mathrm{N}$ deposition on forest ecosystems depend on many factors, such as species composition, land-use history, and hydrological flow associated with seasonal patterns in precipitation (Adams et al. 1993; Aber et al. 1995; Fenn et al. 1998). Coniferous forests have been shown to respond differently than deciduous forests to nitrogen inputs (Aber et al. 1989). Conifer stands of North America and Europe receive high $\mathrm{N}$ inputs and, consequently, show increased $\mathrm{NO}_{3}$ leaching, nutrient uptake imbalances, and tree mortality (Nihlgard 1985; Vitousek et al. 1997). In comparison, there are many deciduous, hardwood forests receiving high $\mathrm{N}$ inputs that do not display these symptoms (Aber et al. 1995). Researchers have suggested that deciduous forests may show a delayed response to elevated $\mathrm{N}$ deposition, suggestive of a higher $\mathrm{N}$ retention capacity than coniferous forests. However, given greater increases in $\mathrm{N}$ inputs, or chronic input at current levels, deciduous forests will eventually show symptoms of $\mathrm{N}$ saturation, similar to coniferous stands (Adams et al. 1993; Aber et al. 1995; Aber et al. 1998; Fenn et al. 1998).

Nitrogen saturation is characterized by a suite of plant and soil-level changes that result in the gradual relief of biotic $\mathrm{N}$ limitation and reduction of soil $\mathrm{N}$ retention (Aber et al. 1998; 
Fenn et al. 1998). Many studies of deciduous hardwood forests have examined the effects of $\mathrm{N}$ saturation by experimentally manipulating $\mathrm{N}$ inputs (Adams et al. 1993; Aber et al. 1995; Peterjohn et al. 1996). These studies have shown that initially, $\mathrm{N}$ fertilization stimulates $\mathrm{N}$ mineralization, foliar $\mathrm{N}$ concentrations, photosynthetic rates, and productivity. However, as $\mathrm{N}$ additions continue and $\mathrm{N}$ limitation of biotic processes is relieved, soil acidity, cation leaching, and foliar nutrient imbalances increase. Deciduous hardwood trees may experience reduced $\mathrm{N}$ use efficiency, reduced photosynthesis, and decreased growth (Pardo and Driscoll 1996). For such symptoms of $\mathrm{N}$ saturation to occur, plant $\mathrm{N}$ demand must be satisfied. Therefore, it has been suggested that the key indicators of $\mathrm{N}$ status and the degree of $\mathrm{N}$ saturation in these systems may be those processes interfacing soil and plants (Aber et al. 1998).

Many interactions within forest ecosystems are strongly linked to foliar $\mathrm{N}$ concentration. Foliar $\mathrm{N}$ concentrations determine net photosynthesis, which regulates ecosystem carbon balance (Field \& Mooney 1986). As net photosynthetic rates increase, more carbon is allocated toward biomass production and mycorrhizal nitrogen assimilation, which could result in nitrogen immobilization (Stark and Hart 1996). In this way, photosynthesis also drives soil N cycling and it has been suggested that foliar $\mathrm{N}$ may be the best indicator of $\mathrm{N}$ saturation in a forest ecosystem (Aber et al. 1998).

Foliar $\mathrm{N}$ concentration in also a strong determinant of foliar quality to insect herbivores (Lance et al. 1986; Joseph \& Kelsey 1994). Like trees in these systems, insect herbivores have large requirements for $\mathrm{N}$, as it is integral to their structure and metabolism (Mattson 1980). Many studies have shown that insect growth, development rates, and survival are greater with increases in foliar N concentration (Bryant et al. 1987; Kainulainen et al. 1996; Murakami and 
Wada 1997). Consequently, foliar $\mathrm{N}$ concentration may also be a strong indicator of forest tree susceptibility to insect herbivores (van Rensburg et al. 1997).

Multiple environmental factors (e.g., water, nutrient, and light availability) interactively affect soil $\mathrm{N}$ mobility, $\mathrm{N}$ uptake, net photosynthesis, and carbon allocation (Dudt and Shure 1994; Ibrahim et al. 1997; van Rensburg et al. 1997). North American forests receiving elevated nitrogen inputs are also predicted to experience increases in the occurrence and severity of drought (Wetherald and Manabe 1999). The effects of nitrogen and water availability on the differential allocation of plant carbon and nitrogen compounds to primary or secondary metabolism has been described by the carbon-nutrient balance (CNB) hypothesis (Bryant et al. 1983; Hoft et al. 1996; Gebauer et al. 1998). Some predictions of this hypothesis are that when $\mathrm{N}$ is not limiting to plant growth, allocation is directed toward primary metabolism (growth processes), rather than C-based secondary metabolism (non-growth processes). Conversely, when $\mathrm{N}$ limits growth more than photosynthesis, the synthesis of C-based secondary compounds is stimulated and primary metabolism is compromised. Soil water availability is tightly coupled with plant nitrogen availability and this affects plant $\mathrm{C}$ and $\mathrm{N}$ balance (Fig. 1.1). If water availability is abundant in a high $\mathrm{N}$ environment, plant growth and photosynthesis are stimulated and leaf $\mathrm{N}$ concentrations are high relative to $\mathrm{C}$-based secondary compounds. This results in high foliar quality for insect herbivores, as indicated by higher growth rates, development rates, and survival. Furthermore, insects require less high quality foliage to satisfy their nutritional needs, so consumption rates are typically lower when larvae feed on high quality foliage (Slansky 1993). In the alternate situation (Fig. 1.1), when water availability is limited in a high $\mathrm{N}$ environment, plant $\mathrm{N}$ availability is also limited. As a result, plant growth and photosynthesis 
Fig. 1.1 Interactive effects of elevated $\mathrm{N}$ deposition and high or low water availability on plant growth, physiology, foliar chemistry, and generalist insect herbivore performance. $(+)$ indicates change in a positive direction, while (-) indicates change in a negative direction. 

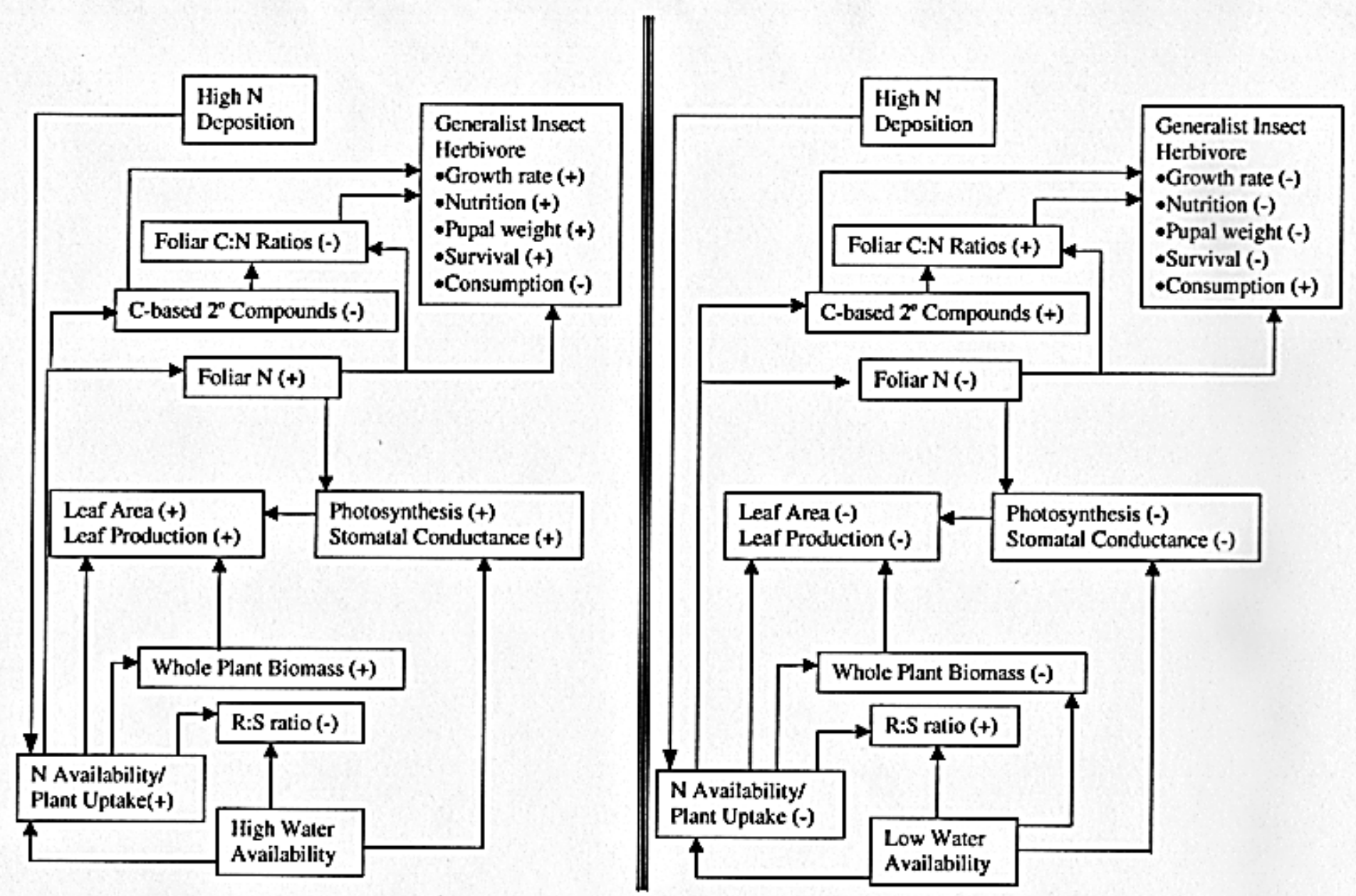

Fig. 1.1 
are reduced and stored carbon is allocated toward the increased production of C-based secondary compounds. In this low water scenario, leaf quality to insect herbivores is lower (higher leaf $\mathrm{C} / \mathrm{N}$ ratios) and measures of insect performance, such as growth rates, development rates, and survival decrease. Larvae require more leaf tissue to satisfy their high $\mathrm{N}$ requirement and, as a result, consumption rates could increase (Slansky and Wheeler 1992). This is one of the mechanisms that could increase the defoliation and susceptibility of water-limited plants to insect herbivory. Another mechanism for the increased susceptibility of water-limited plants is proposed by the plant-stress hypothesis (White 1984). This hypothesis states that water stress promotes the increased concentration of soluble leaf N. Severely water-stressed plants may also lack the resources to produce metabolically-expensive C-based secondary compounds. In this case, leaf $\mathrm{C} / \mathrm{N}$ ratios decrease and consumption rates are lower, but insects will perform better on water-stressed plants, producing larger populations with greater numbers of offspring, effectively making them more susceptible to herbivory.

The objectives of the following experiment was to determine the effects of elevated $\mathrm{N}$ and variations in water availability on plant growth, photosynthetic response, and foliar quality to a generalist insect herbivore, gypsy moth (Lymantria dispar L.). This study tested the hypothesis that deciduous tree seedlings grown under elevated $\mathrm{N}$ deposition are more susceptible to drought and insect herbivory. These effects were examined for tree species that differ in their requirements for resources and their suitability as hosts for the generalist insect herbivore, gypsy moth. I grew gray birch (Betula populifolia, Marsh.), yellow birch (B. alleghaniensis, Britton), and red oak (Quercus rubra, L.) seedlings for two years in a field study under three $\mathrm{N}$ and three water availabilities. During the second year, I measured photosynthetic rates, growth rates and patterns of biomass allocation, and assayed foliage for numerous $\mathrm{N}$ and $\mathrm{C}$-containing 
compounds. I also conducted feeding trials with gypsy moth larvae using foliage from fieldgrown trees and determined insect growth rates, consumption rates, and nutritional indices. I expected that seedlings grown under elevated $\mathrm{N}$ would be more adversely affected by reductions in water supply than seedlings grown under no $\mathrm{N}$ addition, due to greater leaf production, lower root production, and greater transpirational water loss. I also hypothesized that $\mathrm{N}$ fertilization and reduced water availability would alter foliar quality for gypsy moth larvae in ways that would increase seedling susceptibility to herbivory, either through increased larval consumption of lower quality foliage, or improved larval performance on higher quality foliage. The ultimate goal of this research was to explore the potential for drought-induced responses under elevated $\mathrm{N}$ conditions, as well as to explain factors that affect defoliation by generalist insect folivores within northeastern deciduous forests. The impetus for this study is the evidence that accelerated $\mathrm{N}$ deposition and rainfall patterns affect foliar $\mathrm{N}$, a unifying determinant of ecosystem $\mathrm{N}$ status and foliar quality to generalist insect herbivores (Larsson et al. 1986; Bryant et al. 1987; Aber et al. 1998). 


\section{References}

Aber, J. D., W. McDowell, K. Nadelhoffer, A. Magill, G. Berntson, M. Kamakea, S. McNulty, W. Currie, L. Rustad, and I. Fernandez. 1998. Nitrogen saturation in temperate forest ecosystems. Bioscience 48(11): 921-934.

Aber, J. D., A. Magill, S. McNulty, R. D. Boone, K. J. Nadelhoffer, M. Downs, and R. Hallett. 1995. Forest biogeochemistry and primary production altered by nitrogen saturation. Water, Air, and Soil Pollution 85: 1665-1670.

Aber, J. D., K. J. Nadelhoffer, P. Steudler, and J. M. Melillo. 1989. Nitrogen saturation in northern forest ecosystems. Bioscience 39: 378-386.

Adams, M. B., P. J. Edwards, F. Wood, and J. N. Kochenderfer. 1993. Artificial watershed acidification on the Fernow Experimental Forest, USA. Journal of Hydrology 150: 505-519.

Bryant, J. P., T. P. Clausen, P. B. Reichardt, M. C. McCarthy, and R. A. Werner. 1987. Effect of nitrogen fertilization upon the secondary chemistry and nutritional value of quaking aspen (Populus tremuloides Michx.) leaves for the large aspen tortrix (Choristoneura conflictana (Walker)). Oecologia 73: 513-517.

Bryant, J. P., F. S. Chapin III. and D. R. Klien. 1983. Carbon/nutrient balance of boreal plants in relation to vertebrate herbivory. Oikos. 40:357-368.

Dudt, J. F. and D. J. Shure. 1994. The influence of light and nutrients on foliar phenolics and insect herbivory. Ecology 75(1): 86-98.

Erelli, M. C., M. P. Ayres, and G. K. Eaton. 1998. Altitudinal patterns in host suitability for forest insects. Oecologia 117: 133-142. 
Fenn, M. E., M. A. Poth, J. D. Aber, J. S. Baron, B. T. Bormann, D. W. Johnson, A. D. Lemly, S. G. McNulty, D. F. Ryan, and R. Stottlemyer. 1998. Nitrogen excess in North American ecosystems: predisposing factors, ecosystem responses, and management strategies. Ecological Applications 8(3): 706-733.

Field, C. and H. A. Mooney. 1986. The photosynthesis- nitrogen relationship in wild plants. In On the economy of plant form and function. Ed. T. J. Givnish. Cambridge University Press, Cambridge, Mass., pp 25-55.

Galloway, J. N. 1995. Acid deposition: perspectives in time and space. Water, Air, and Soil Pollution 85: 15-24.

Gebauer, R. L. E., B. R. Strain, and J. F. Reynolds. 1998. The effect of elevated $\mathrm{CO}_{2}$ and $\mathrm{N}$ availability on tissue concentrations and whole plant pools of carbon-based secondary compounds in loblolly pine (Pinus taeda). Oecologia 113: 29-36.

Höft, M., R. Verpoorte, and E. Beck. 1996. Growth and alkaloid contents in leaves of Tabernaemontana pachysiphon Stapf (Apocynaceae) as influenced by light intensity, water, and nutrient supply. Oecologia 107: 160-169.

Ibrahim, L., M. F. Proe, and A. D. Cameron. 1997. Main effects of nitrogen supply and drought stress unpon whole-plant carbon allocation in poplar. Canadian Journal of Forest Research 27: 1413-1419.

Joseph G. and R. G. Kelsey. 1994. Acceptability and suitability of Douglas-fir as a secondary host for gypsy moth (Lepidoptera: Lymantriidae). Environmental Entomology 23(2):396-405. 
Kainulainen, P., J. Holopainen, V. Palomaki, and T. Holopainen. 1996. Effects of nitrogen fertilization on secondary chemistry and ectomycorrhizal state of scots pine seedlings and on growth of grey pine aphid. Journal of Chemical Ecology 22(4): 617636.

Lance D. R., J. S. Elkinton, and C. P. Schwalbe. 1986. Responses of gypsy moth larvae (Lepidoptera: Lymantriidae) to foliage of oaks from naturally infested sites on Cape Cod, Massachusetts. Journal of Entomological Science 26(2): 214-222.

Larsson, S., A. Wiren, L. Lundgren, anT. Ericsson. 1986. Effects of light and nutrient stress on leaf phenolic chemistry in Salix dasyclados and susceptibility to Galerucella lineola (Coleoptera). Oikos 47: 205-210.

Mattson W. Jr. 1980. Herbivory in relation to plant nitrogen content. Annual Review of Ecology and Systematics. 11:119-161.

Murakami, M. and N. Wada. 1997. Difference in leaf quality between canopy trees and seedlings affects migration and survival of spring-feeding moth larvae. Canadian Journal of Forest Research 27: 1351-1356.

Nihlgard, B. 1985. The ammonium hypothesis- an additional explanation to the forest dieback in Europe. Ambio 14(1): 2-8.

Ollinger, S. V., J. D. Aber, G. M. Lovett, S. E. Millham, R. G. Lathrop, and J. M. Ellis. 1993. A spatial model of atmospheric deposition for the Northeastern U. S. Ecological Applications 3(3): 459-472.

Pardo, L. H. and C. T. Driscoll. 1996. Critical loads for nitrogen deposition: Case studies at two northern hardwood forests. Water, Air, and Soil Pollution 89: 105-128. 
Peterjohn, W. T., M. B. Adams, and F. S. Gilliam. 1996. Symptoms of nitrogen saturation in two central Appalachian hardwood forest ecosystems. Biogeochemistry 35: $507-522$.

Slansky, F. Jr. 1993. Nutritional ecology: The fundamental quest for nutrients. In Caterpillars: Ecological and evolutionary constraints on foraging. Eds. N. E. Stamp and T. M. Casey. Chapman and Hall, New York, pp. 29-91.

Slansky, F. Jr. and G. S. Wheeler. 1992. Caterpillars' compensatory feeding response to diluted nutrients leads to toxic allelochemical dose. Entomologia Experimentalis et Applicata 65: $171-186$.

Stark, J. M. and S. C. Hart. 1996. High rates of nitrification and nitrate turnover in undisturbed coniferous forests. Nature: $61-64$.

van Rensburg, L, G. H. F. Krüger, B. Ubbink, M. C. Scholes, and J. Peacock. 1997. A phytocentric perspective of Asterolecanium quercicola Bouché infestation on Qercus robur L. trees along an urbanization gradient. South African Journal of Botany 63(1): 25-31.

Vitousek, P. M., J. D. Aber, R. W. Howarth, G. E. Likens, P. A. Matson, D. W. Schindler, W. H. Schlesinger, and G. D. Tilman. 1997. Human alteration of the global nitrogen cycle: Causes and consequences. In Issues in Ecology, number 1. Ed. D. Tilman. Ecological Society of America, Washington D.C., pp. 1-15.

Wetherald, R. T. and S. Manabe. 1999. Detectability of summer dryness caused by greenhouse warming. Climatic Change 43: 495-511.

White, T. C. R. 1984. The abundance of invertebrate herbivores in relation to the availability of nitrogen in stressed food plants. Oecologia 63: 90-105. 


\section{Chapter 2}

Effects of $\mathbf{N}$ and water availability on growth and biomass allocation of three deciduous species in a field study 


\section{ABSTRACT}

Species with different life history traits vary in the way they grow and allocate biomass under high $\mathrm{N}$ inputs. Furthermore, there is increasing evidence that, trees exposed to elevated atmospheric $\mathrm{N}$ deposition respond in ways that increase their susceptibility to drought. I examined growth rates and biomass partitioning of gray birch (Betula populifolia), yellow birch (B. alleghaniensis), and red oak seedlings (Quercus rubra) grown in a field study for two years under varying levels of $\mathrm{N}$ and water availability. $\mathrm{N}$ addition enhanced total biomass, relative growth rates, leaf area production, and net assimilation rates of both birch species, and these responses were more pronounced for yellow birch seedlings. The proportion of root weight to total biomass and root:shoot ratios of red oak seedlings were reduced with $\mathrm{N}$ addition, but this did not affect total biomass production or seedling growth rates. Although I observed no significant effects of water availability on seedling growth and biomass allocation, I suggest that the $\mathrm{N}$-induced increase in leaf area exhibited by birch seedlings and decrease in root production by red oak seedlings could increase their potential for transpirational water loss and reduced water uptake. I found a trend that indicated that the effects of $\mathrm{N}$ availability depended on water availability, such that reduced water availability diminished the $\mathrm{N}$-induced enhancement of relative growth rates. I attribute differences in seedling growth rates among species to differences in biomass partioning and these data indicate that, under elevated atmospheric $\mathrm{N}$ deposition, these changes may differentially enhance seedling water stress during drought periods. 


\section{INTRODUCTION}

Forest ecosystems of the northeastern United States receive high amounts of atmospheric $\mathrm{N}$ deposition (Fenn et al. 1998). Tree species may respond to elevated $\mathrm{N}$ deposition in ways that can greatly increase their susceptibility to drought (Rosengren-Brinck and Nihlgard 1995;

Wendler and Millard 1996). For example, $\mathrm{N}$ addition could stimulate aboveground biomass to a greater extent than belowground biomass production and, thus, raise transpirational water loss (Lippert et al. 1996). Excessive atmospheric $\mathrm{N}$ deposition can also lead to soil acidification and reduced nutrient uptake by plants (Aber et al. 1989; Huttl 1990). In this case, trees may experience reductions in root biomass and, consequently, reduced water uptake (Emmett et al. 1995; DeVisser et al. 1996).

Elevated $\mathrm{N}$ inputs have been shown to differentially affect growth, mortality, and seedling regeneration of coniferous and deciduous tree species (Aber et al. 1995; Hallett and Hornbeck 1997; Aber et al. 1998). In northeastern forests of North America, there is evidence that this differential response could lead to the replacement of slower-growing, coniferous stands by faster-growing deciduous forests (McNulty et al. 1996; Fenn et al. 1998). If deciduous seedling growth occurs differentially across species in response to elevated $\mathrm{N}$ and variations in water supply, competitive interactions could ultimately lead to shifts in species composition. The outcome of these competitive interactions could further influence the susceptibility of these forests to the process of N saturation (Waring 1987; Fenn et al. 1998; Peterjohn et al. 1999).

Studies of the effects of water availability on growth of trees exposed to excessive $\mathrm{N}$ deposition have focused on coniferous species (Raison et al. 1990; DeVisser 1995; RosengrenBrinck and Nihlgard 1995; DeVisser et al. 1996; Lippert et al. 1996). In this study, I examined 
how seedling growth of three deciduous tree species was altered by varying elevated $\mathrm{N}$ and water availability in a field setting. Gray birch (Betula populifolia Marsh), yellow birch (B.

alleghaniensis Britton), and red oak (Quercus rubra L.) differ in their life history traits, have overlapping geographic ranges throughout northern Appalachian forests, and can co-occur during transitional stages of succession (Liptzin and Ashton 1999). Gray birch is a pioneer species that tolerates lower soil fertility and is faster growing than yellow birch and red oak. Furthermore, red oak and gray birch are more drought tolerant than yellow birch. I hypothesized that gray birch would be more responsive to $\mathrm{N}$ fertilization due to its faster growth rates and, as a result, be more susceptible to drought injury than later successional yellow birch and red oak. The objectives of this study were to compare seedling growth and biomass allocation of three, co-occurring deciduous tree species under varying $\mathrm{N}$ and water availability and to identify seedling traits that account for differences in RGR. 


\section{METHODS}

\section{Site Description and Tree Seedling Growth}

Tree seedlings were grown for two years under $\mathrm{N}$ and water treatments at the WVU Agronomy Farm in Morgantown, West Virginia $\left(39^{\circ} 40^{\prime} \mathrm{N}, 79^{\circ} 54^{\prime} \mathrm{W}\right.$; Fig. 2.1). This site has a relatively long history of being used for pasture and crop cultivation. Soils at this site are classified as moderately well-drained Dormont and Guernsey silt loams with 8 to 15 percent slopes and are described as highly suitable for tree growth (Wright et al. 1982).

Seeds of gray birch, yellow birch, and red oak were collected from Pennsylvania sources (F.W. Schumacher Co., Inc., Sandwich, MA). Seeds were stratified for three months at $4^{\circ} \mathrm{C}$ and germinated in May 1997 under greenhouse conditions $\left(29^{\circ} \mathrm{C}\right.$ day, $18^{\circ} \mathrm{C}$ night $)$ in $5 \mathrm{~L}$ tree pots using potting soil low in nutrients (Jungle-Gro ${ }^{\mathrm{TM}}$ brand). Seedlings were watered as needed to maintain moist soil and were provided with a dilute, 1/4 strength Miracle-Gro solution (15:30:15) biweekly.

In early October 1997, five seedlings per species were transplanted into nine blocks of three, $3 \times 2$ m subplots (three-way split-plot design; Fig. 2.2). Also transplanted into each subplot were five black locust seedlings (Robinia pseudoacacia L.), for a total of 20 seedlings in each subplot. Black locust was excluded from growth and biomass analyses because of the time investment required to harvest this species and the damage caused by herbivory on this species during several insect outbreaks at the field site. Nitrogen treatments included ambient (no N addition) and two levels of $\mathrm{N}$ fertilization. Fertilized blocks received a single application of dry $\mathrm{NH}_{4} \mathrm{NO}_{3}$ at levels of $100 \mathrm{~kg} / \mathrm{ha} / \mathrm{yr}(\mathrm{n}=3)$ and $200 \mathrm{~kg} / \mathrm{yr} / \mathrm{ha}(\mathrm{n}=3)$ at the beginning of March 1998 
Fig. 2.1 Tree seedlings growing in year two at the experimental site under $\mathrm{N}$ and water treatments. 


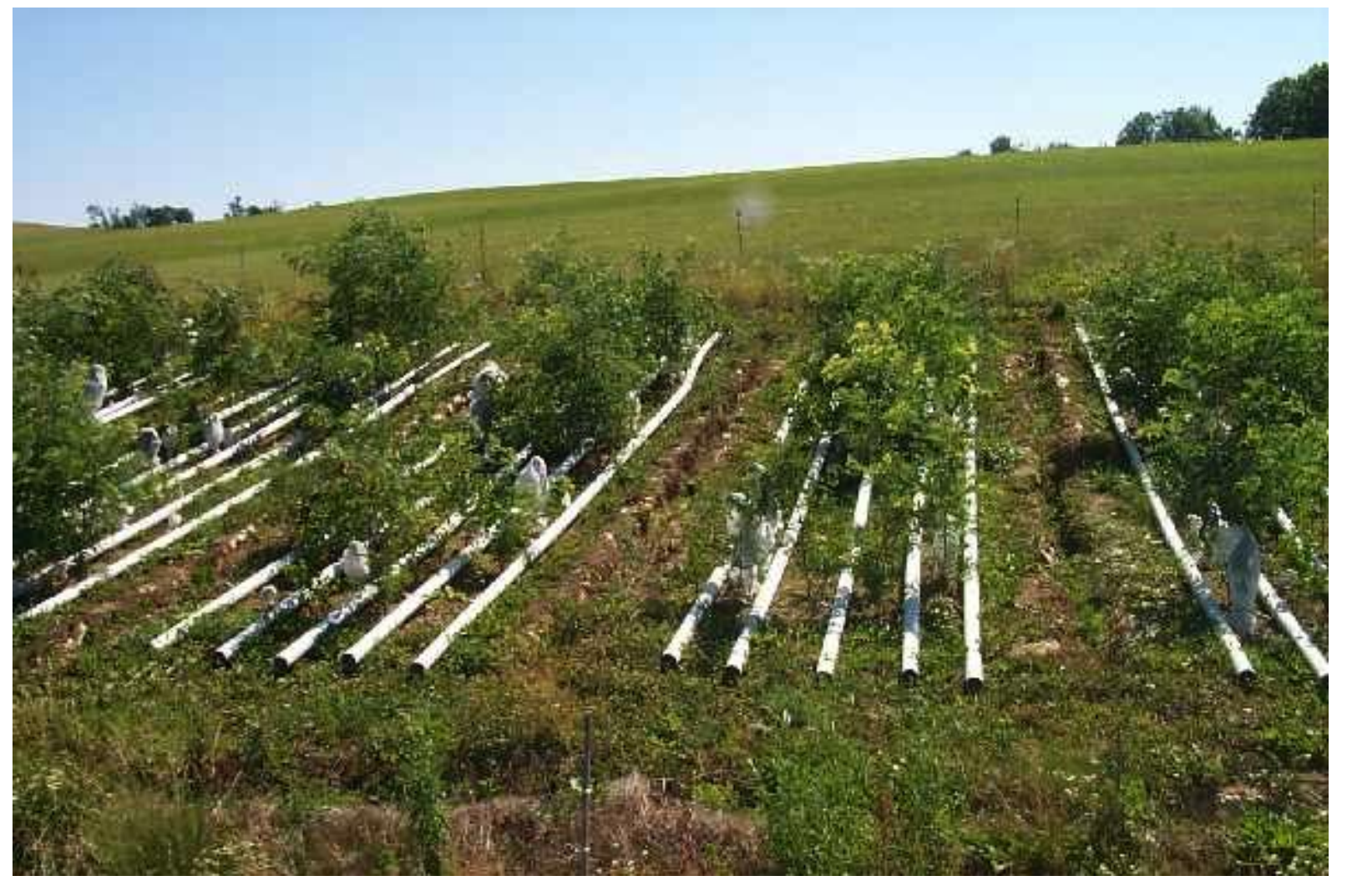

Fig. 2.1 
Fig. 2.2. Experimental layout of the three-way split plot design used to manipulate nitrogen and water availability to deciduous tree seedlings in the field. Key features depicted are orientation of $3 \times 2 \mathrm{~m}$ subplots relative to the sloping hillside, position of tree seedlings relative to drainage pipe, and trenches dug to eliminate surface and subsurface nutrient and water flow to $3 \mathrm{~m}$ between nitrogen treatments and around the perimeter of the experimental area. Nitrogen and water treatments are labeled within each subplot. 


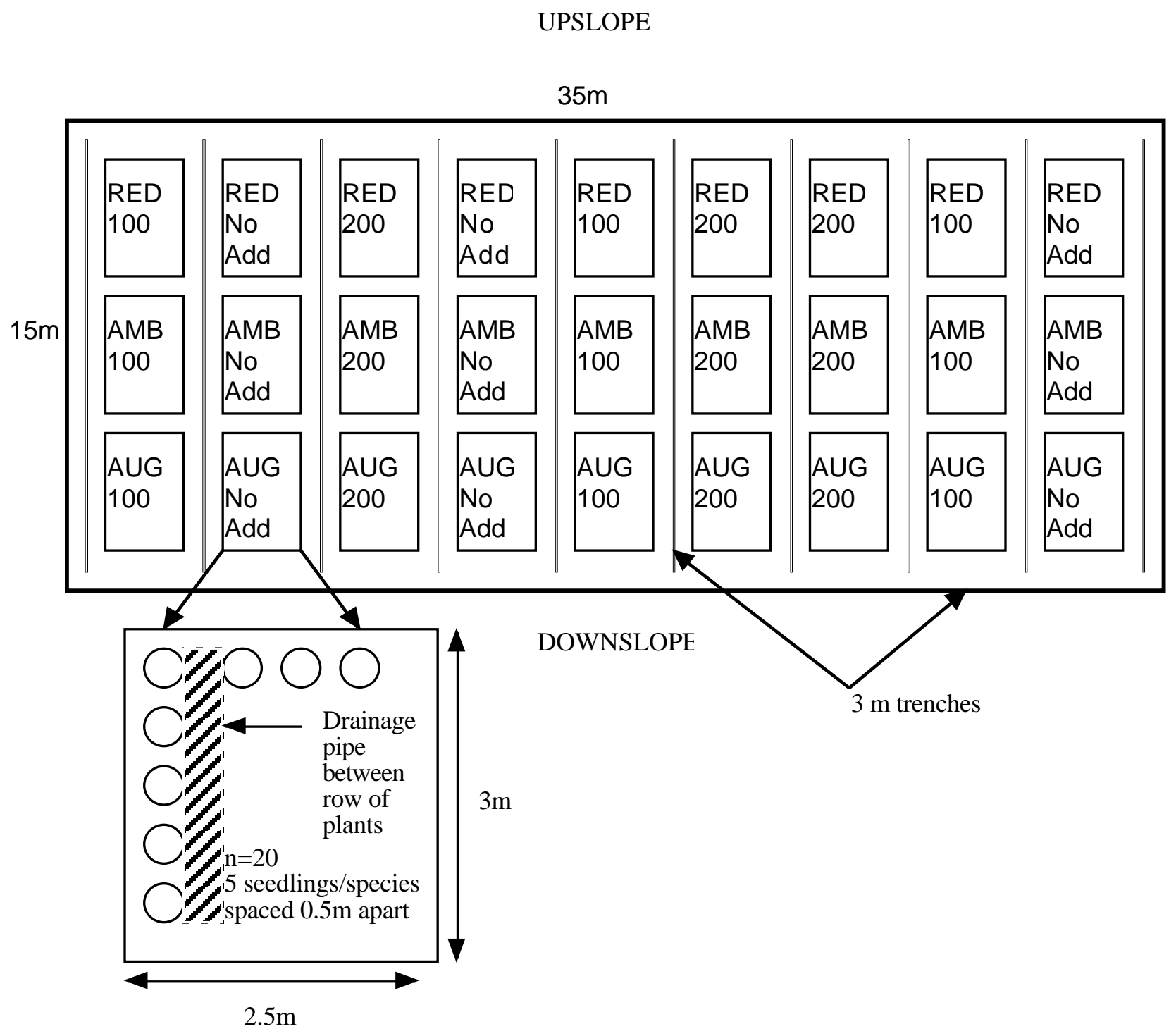

Figure 2.2 
and March 1999. $\mathrm{NH}_{4} \mathrm{NO}_{3}$ was broadcast over the soil around the base of the seedlings (radius $=0.5 \mathrm{~m}) . \mathrm{N}$ levels for supplemented plots approximate a high level of $\mathrm{N}$ deposition into some fertilized Appalachian forests (35 kg N/ha; Gilliam et al. 1996) and a doubled level (70 kg N/ha), given the future of increased $\mathrm{N}$ inputs to these systems (Galloway 1995). Three control blocks received no fertilizer addition.

Water availability to seedlings relied on natural rainfall events and was either reduced, ambient, or augmented. Water availability was reduced in nine, upslope subplots by capturing rainwater in open drainage pipes that covered approximately $25 \%$ of the subplot area. This water was diverted to nine, downslope, augmented subplots. A third set of nine supblots, flanked by the low and high-water subplots, served as an ambient condition. The ambient subplots had closed drainage pipes running through them, which did not alter the input of water from rainfall. Surface and subsurface water and nutrient flow was eliminated down to $3 \mathrm{~m}$ by plastic-lined trenches that separated the nine $\mathrm{N}$ treatment blocks from one another and the surrounding area. Soil water content was measured approximately weekly and precipitation and temperature were recorded daily throughout the growing seasons in 1998 and 1999 (Fig. 2.3). Differences among water treatments were maintained during the growing seasons by either the drainage pipe installation, the slightly-graded slope that the seedlings were planted on, or a combination of the two. Soil water content in reduced plots was lower than soil water content in augmented plots at every measurement date. The differences in soil water content between these water treatments ranged from below 5\% to about 10\%. Furthermore, during the 1999 growing season a drought occurred, as indicated by the overall lower precipitation and soil moisture values for that year. 
Fig. 2.3. Percent soil moisture and weekly precipitation for 1998 and 1999 growing seasons.

Soil moisture was measured with TDR at a constant depth of $15 \mathrm{~cm}$ probes. Rainfall was

measured using a rain gauge at the WVU Agronomy Farm. The x-axis is labeled by month, from June through October. 


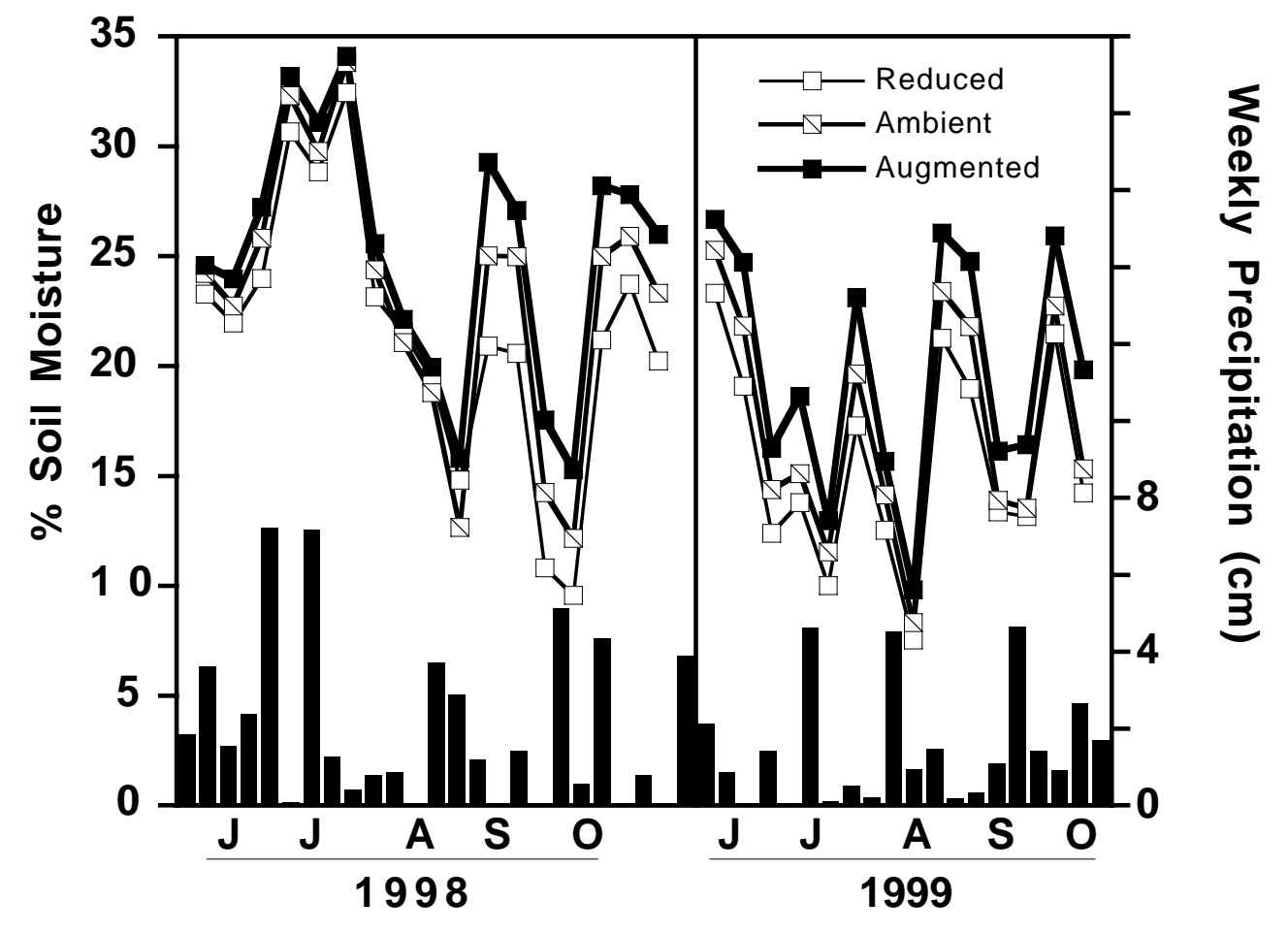

Fig. 2.3 


\section{Measurements}

Seedling height and stem diameter were measured monthly to non-destructively determine growth rate during the two-year experiment. To calculate seedling relative growth rate (RGR) and net assimilation rate (NAR), a subsample of seedlings from each species $(n=20)$ was harvested prior to nitrogen and water treatment and initial seedling biomass was calculated using the allometric relationship between seedling height and whole plant biomass determined by regression with harvested seedlings.

In September 1999, seedlings were harvested from a randomly-chosen sample of seedlings within each $\mathrm{N} x$ Water $\mathrm{x}$ Species treatment group $(\mathrm{n}=3-5)$. Seedlings were separated into leaves and stems and dried at $65^{\circ} \mathrm{C}$ to a constant weight to determine aboveground biomass. Leaf mass per unit area (LMA) was determined for leaf samples taken from each seedling and, with total seedling leaf mass, was used to calculate total seedling leaf area. To determine total seedling biomass, roots of these seedlings were harvested by hand (including fine roots), washed using a $3 \mathrm{~mm}$ sieve, and dried at $65^{\circ} \mathrm{C}$ to a constant weight. The following formulae were used to calculate RGR and NAR

$$
\begin{aligned}
& \mathrm{RGR}=\left(\ln W_{2}-\ln W_{1}\right) /\left(t_{2}-t_{1}\right) \\
& \mathrm{NAR}=\left[\left(W_{2}-W_{1}\right) /\left(A_{2}-A_{1}\right)\right]\left[\left(\ln A_{2}-\ln A_{1}\right) /\left(t_{2}-t_{1}\right)\right]
\end{aligned}
$$

$W_{2}$ and $W_{1}$ represent total seedling biomass and $A_{2}$ and $A_{1}$ represent total seedling leaf area at day $720\left(t_{2}\right)$ and day $1\left(t_{1}\right)$. LAR was calculated as the ratio of total seedling leaf area to total seedling biomass. Root to shoot ratio (R:S), leaf weight ratio (LWR), stem weight ratio (SWR), and root weight ratio (RWR) were also determined. LWR, SWR, and RWR were calculated as the proportional weight of the given organ per total seedling biomass. 


\section{Statistical Analysis}

All measurements of growth were analyzed using three-way ANOVAs to test for the effects of $\mathrm{N}$, water, species, and their interactions (JMP, SAS Institute, Inc., Cary, NC). R:S ratios were $\ln$ transformed to normally distribute data. This field experiment was planted as a three-way split plot design, with nitrogen treatments nested within blocks (Fig. 2.2). However, during final harvest some seedlings were excluded from the sample pool because they were used for feeding trials in a separate herbivory study. Lack of replication at the Block x N x Water x Species level resulted in the elimination of block effects from the statistical model. Sample size was unequal across treatment combinations and ranged from three to five seedlings. Nitrogen, water, species, and their interactions were all fixed effects within the model. Effects were considered statistically significant if $\mathrm{p}<0.05$. 


\section{RESULTS}

Biomass production and allocation significantly differed across the three species (Table 2.1). When averaged across nitrogen and water treatments, gray birch seedlings produced more biomass than yellow birch and red oak seedlings (Fig. 2.4). R:S ratios of red oak seedlings were approximately three times greater than R:S ratios of gray and yellow birch seedlings (Fig. 2.5). RWR of red oak seedlings exceeded those of gray and yellow birch seedlings, while yellow birch seedlings allocated more biomass to stems and leaves than gray birch and red oak (Fig. 2.5). Gray birch seedlings exhibited greater leaf area production and produced thicker leaves (higher LMA) than yellow birch and red oak seedlings (Table 2.2). Yellow birch had greater LAR than gray birch, which was greater than red oak, while NAR of gray birch was greater than red oak, which was greater than yellow birch. LAR and NAR collectively determine RGR which was greatest for gray birch, followed in decreasing order by yellow birch and red oak (Table 2.2).

Averaged across all species, $\mathrm{N}$ availability significantly affected total biomass

production, R:S ratios, RWR, LA production, NAR, and RGR (Table 2.1). Furthermore, the response of these parameters to $\mathrm{N}$ availability was species dependent (Table 2.1). $\mathrm{N}$ addition stimulated total biomass production in gray and yellow birch, but not in red oak (Fig. 2.4). Biomass production of gray birch seedlings averaged $133 \%$ greater when grown under $\mathrm{N}$ fertilized treatments, compared to treatments where no $\mathrm{N}$ was added. For yellow birch seedlings, average biomass stimulation of fertilized seedlings was $267 \%$ greater than unfertilized treatments.

While $\mathrm{N}$ availability did not significantly affect $\mathrm{R}: \mathrm{S}$ ratios of the two birch species, $\mathrm{R}: \mathrm{S}$ ratios of red oak seedlings grown under the highest $\mathrm{N}$ level were $31 \%$ lower than those grown 
Table 2.1. Summary of three-way ANOVAs showing p values for the effects of species, nitrogen (N), water availability, and their interactive effects on total biomass (TB), root to shoot ratio (R/S), root weight ratio (RWR), stem weight ratio (SWR), leaf weight ratio (LWR), leaf area (LA), leaf mass per unit area (LMA), leaf area ratio (LAR), net assimilation rate (NAR), and relative growth rate (RGR). Statistically significant values $(\mathrm{p}<0.05)$ are in bold, while trends $(0.05<\mathrm{p}<0.10)$ are denoted by $*$.

\begin{tabular}{lrrrrrrrrrr}
\hline Source & TB & R/S & RWR & SWR & LWR & LA & LMA & LAR & NAR & RGR \\
\hline Species & $<\mathbf{0 . 0 1}$ & $<\mathbf{0 . 0 1}$ & $<\mathbf{0 . 0 1}$ & $<\mathbf{0 . 0 1}$ & $<\mathbf{0 . 0 1}$ & $<\mathbf{0 . 0 1}$ & $<\mathbf{0 . 0 1}$ & $<\mathbf{0 . 0 1}$ & $<\mathbf{0 . 0 1}$ & $<\mathbf{0 . 0 1}$ \\
N & $<\mathbf{0 . 0 1}$ & $\mathbf{0 . 0 3}$ & $\mathbf{0 . 0 5}$ & 0.10 & 0.76 & $<\mathbf{0 . 0 1}$ & 0.70 & 0.84 & $<\mathbf{0 . 0 1}$ & $<\mathbf{0 . 0 1}$ \\
Water & 0.58 & 0.23 & 0.15 & 0.84 & 0.39 & 0.59 & 0.32 & 0.64 & 0.42 & 0.74 \\
Species x N & $<\mathbf{0 . 0 1}$ & $<\mathbf{0 . 0 1}$ & $<\mathbf{0 . 0 1}$ & 0.16 & 0.32 & $\mathbf{0 . 0 2}$ & 0.16 & 0.27 & $\mathbf{0 . 0 1}$ & $\mathbf{0 . 0 1}$ \\
Species x Water & 0.73 & 0.13 & 0.11 & 0.58 & 0.32 & 0.68 & 0.44 & 0.67 & 0.93 & 0.97 \\
N x Water & 0.22 & 0.14 & 0.19 & 0.76 & 0.70 & 0.10 & $* 0.07$ & 0.17 & 0.11 & $* 0.07$ \\
Species x N x Water & 0.91 & 0.35 & 0.49 & 0.58 & 0.88 & 0.91 & 0.39 & 0.53 & 0.46 & 0.86 \\
\hline
\end{tabular}


Fig. 2.4. Total biomass production of gray birch, yellow birch, and red oak seedlings grown with varying $\mathrm{N}$ and water availability. Standard error bars show $1 \mathrm{SE}+/-$ treatment means. Open bars are reduced water availability, hatched bars are ambient water availability, and closed bars are augmented water availability. 

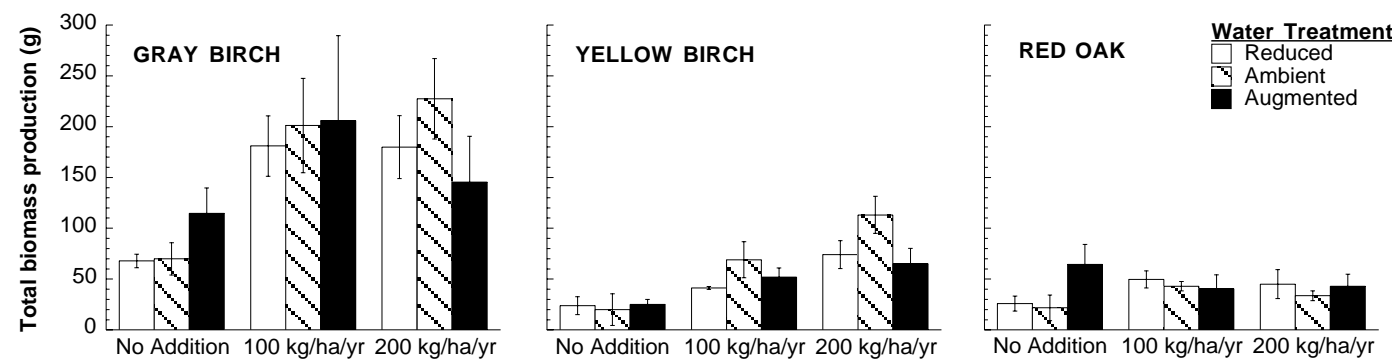

Nitrogen Treatment

Fig. 2.4 
Fig. 2.5. Biomass partitioning of gray birch, yellow birch, and red oak seedlings grown with varying $\mathrm{N}$ and reduced (RED), ambient (AMB), or augmented (AUG) water treatments. Leaf weight ratios (LWR) are light gray, stem weight ratios (SWR) are medium gray, and root weight ratios $(\mathrm{RWR})$ are dark gray. 

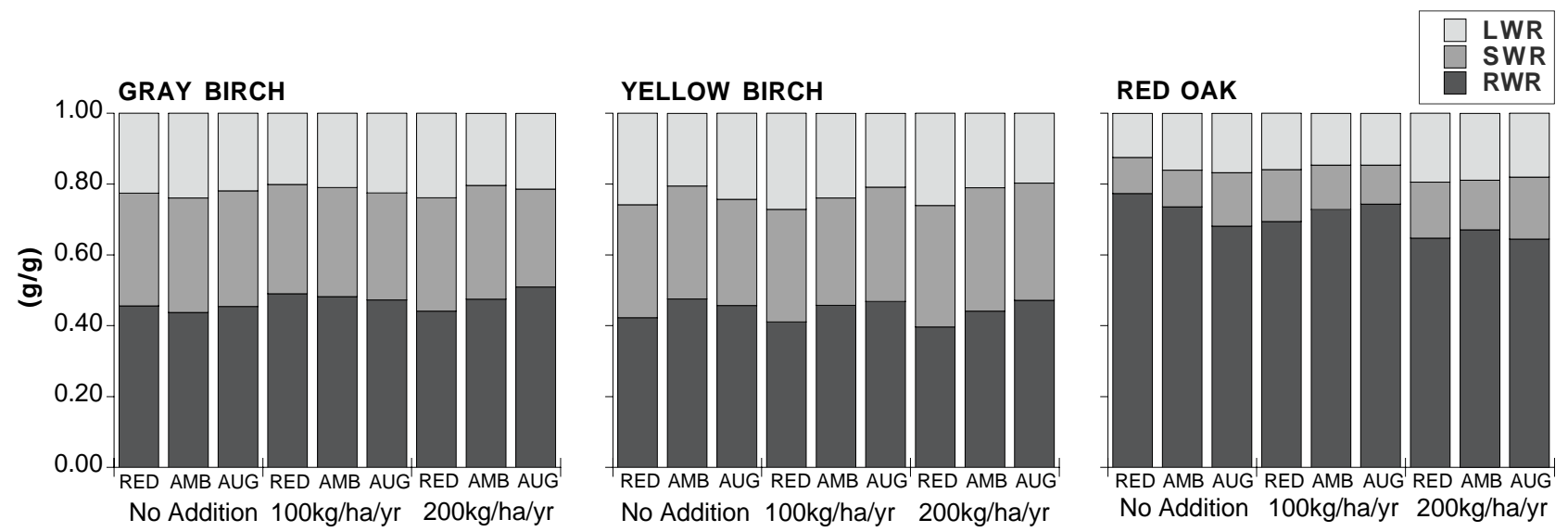

Fig. 2.5 
Table 2.2. Leaf and growth characters of gray birch, yellow birch, and red oak seedlings grown under varying levels of $\mathrm{N}$ and water availability. Values are means $( \pm \mathrm{SE}), \mathrm{n}=3-5$. Leaf and growth characters are leaf area (LA), leaf mass per unit leaf area (LMA), leaf area ratio (LAR), and net assimilation rate (NAR). $\mathrm{N}$ treatments are no $\mathrm{N}$ addition (No), $100 \mathrm{~kg} / \mathrm{ha} / \mathrm{yr} \mathrm{NH} \mathrm{NO}_{3}(100)$, and $200 \mathrm{~kg} / \mathrm{ha} / \mathrm{yr}$ $\mathrm{NH}_{4} \mathrm{NO}_{3}$ (200). Water treatments are reduced (Red), ambient (Amb), and augmented (Aug).

\begin{tabular}{|c|c|c|c|c|c|c|c|c|c|c|}
\hline Character & Species & No/Red & $\mathrm{No} / \mathrm{Amb}$ & No/Aug & 100/Red & 100/Amb & 100/Aug & 200/Red & 200/Amb & 200/Aug \\
\hline $\begin{array}{l}\text { LA } \\
\left(\mathrm{m}^{2}\right)\end{array}$ & $\begin{array}{r}\text { gray birch } \\
\text { yellow birch } \\
\text { red oak }\end{array}$ & $\begin{array}{l}0.19 \pm 0.01 \\
0.09 \pm 0.05 \\
0.04 \pm 0.02\end{array}$ & $\begin{array}{l}0.24 \pm 0.07 \\
0.07 \pm 0.06 \\
0.04 \pm 0.02\end{array}$ & $\begin{array}{l}0.36 \pm 0.07 \\
0.11 \pm 0.03 \\
0.13 \pm 0.04\end{array}$ & $\begin{array}{l}0.50 \pm 0.09 \\
0.17 \pm 0.02 \\
0.10 \pm 0.03\end{array}$ & $\begin{array}{l}0.53 \pm 0.14 \\
0.26 \pm 0.07 \\
0.07 \pm 0.01\end{array}$ & $\begin{array}{l}0.53 \pm 0.18 \\
0.18 \pm 0.06 \\
0.08 \pm 0.03\end{array}$ & $\begin{array}{l}0.51 \pm 0.06 \\
0.31 \pm 0.07 \\
0.11 \pm 0.03\end{array}$ & $\begin{array}{l}0.61 \pm 0.08 \\
0.43 \pm 0.17 \\
0.08 \pm 0.01\end{array}$ & $\begin{array}{l}0.36 \pm 0.10 \\
0.21 \pm 0.06 \\
0.10 \pm 0.03\end{array}$ \\
\hline $\begin{array}{l}\text { LMA } \\
\left(\mathrm{g} \mathrm{m}^{-2}\right)\end{array}$ & $\begin{array}{r}\text { gray birch } \\
\text { yellow birch } \\
\text { red oak }\end{array}$ & $\begin{array}{l}79.9 \pm 2.0 \\
73.0 \pm 2.7 \\
84.5 \pm 4.8\end{array}$ & $\begin{array}{r}73.5 \pm 0.6 \\
78.5 \pm 11.5 \\
81.4 \pm 8.1\end{array}$ & $\begin{array}{l}68.8 \pm 1.5 \\
57.2 \pm 2.7 \\
82.7 \pm 4.2\end{array}$ & $\begin{array}{l}73.0 \pm 4.4 \\
65.3 \pm 5.1 \\
80.6 \pm 5.2\end{array}$ & $\begin{array}{l}80.7 \pm 1.3 \\
63.4 \pm 6.4 \\
84.0 \pm 3.3\end{array}$ & $\begin{array}{l}78.6 \pm 4.8 \\
63.7 \pm 4.7 \\
76.9 \pm 2.5\end{array}$ & $\begin{array}{l}81.6 \pm 2.7 \\
65.5 \pm 2.6 \\
75.7 \pm 3.1\end{array}$ & $\begin{array}{l}75.1 \pm 2.6 \\
58.3 \pm 5.7 \\
80.0 \pm 6.2\end{array}$ & $\begin{array}{l}83.6 \pm 3.8 \\
62.0 \pm 5.1 \\
82.1 \pm 4.0\end{array}$ \\
\hline $\begin{array}{l}\text { LAR } \\
\left(\mathrm{cm}^{2} \mathrm{~g}^{-1}\right)\end{array}$ & $\begin{array}{r}\text { gray birch } \\
\text { yellow birch } \\
\text { red oak }\end{array}$ & $\begin{array}{l}28.3 \pm 1.3 \\
35.2 \pm 5.3 \\
15.2 \pm 3.7\end{array}$ & $\begin{array}{l}32.5 \pm 2.3 \\
27.5 \pm 5.9 \\
20.1 \pm 3.5\end{array}$ & $\begin{array}{l}31.8 \pm 1.3 \\
42.6 \pm 4.7 \\
20.2 \pm 0.6\end{array}$ & $\begin{array}{l}27.5 \pm 0.9 \\
42.2 \pm 4.5 \\
20.3 \pm 5.4\end{array}$ & $\begin{array}{l}26.0 \pm 1.9 \\
38.3 \pm 2.8 \\
17.7 \pm 2.6\end{array}$ & $\begin{array}{l}29.2 \pm 4.7 \\
31.6 \pm 8.3 \\
19.1 \pm 2.0\end{array}$ & $\begin{array}{l}29.2 \pm 1.7 \\
40.1 \pm 4.5 \\
25.8 \pm 4.0\end{array}$ & $\begin{array}{l}27.2 \pm 1.1 \\
35.1 \pm 9.2 \\
24.0 \pm 3.1\end{array}$ & $\begin{array}{l}25.7 \pm 1.6 \\
31.8 \pm 2.6 \\
22.0 \pm 0.7\end{array}$ \\
\hline $\begin{array}{l}\text { NAR } \\
\left(\mathrm{g} \mathrm{m}^{-2} \mathrm{~d}^{-1}\right)\end{array}$ & $\begin{array}{r}\text { gray birch } \\
\text { yellow birch } \\
\text { red oak }\end{array}$ & $\begin{array}{l}0.67 \pm 0.06 \\
0.41 \pm 0.09 \\
0.76 \pm 0.18\end{array}$ & $\begin{array}{l}0.63 \pm 0.09 \\
0.33 \pm 0.23 \\
0.55 \pm 0.25\end{array}$ & $\begin{array}{l}0.76 \pm 0.06 \\
0.38 \pm 0.07 \\
0.94 \pm 0.10\end{array}$ & $\begin{array}{l}1.00 \pm 0.08 \\
0.61 \pm 0.09 \\
0.85 \pm 0.04\end{array}$ & $\begin{array}{l}1.18 \pm 0.17 \\
0.73 \pm 0.06 \\
1.19 \pm 0.20\end{array}$ & $\begin{array}{l}1.11 \pm 0.25 \\
0.90 \pm 0.21 \\
0.84 \pm 0.14\end{array}$ & $\begin{array}{l}1.06 \pm 0.09 \\
0.72 \pm 0.06 \\
0.79 \pm 0.21\end{array}$ & $\begin{array}{l}1.15 \pm 0.08 \\
1.11 \pm 0.13 \\
0.72 \pm 0.08\end{array}$ & $\begin{array}{l}1.04 \pm 0.23 \\
0.84 \pm 0.10 \\
0.61 \pm 0.07\end{array}$ \\
\hline
\end{tabular}


under the no $\mathrm{N}$ addition treatment (Fig. 2.5). RWR of red oak seedlings were slightly sensitive to $\mathrm{N}$ addition, while RWR of the two birch species were not significantly affected by $\mathrm{N}$ availability (Fig. 2.5). Under the highest $\mathrm{N}$ level, RWR of red oak seedlings were reduced by $10 \%$, compared to unfertilized seedlings.

Leaf area increased $103 \%$ and $240 \%$ in the highest $\mathrm{N}$ level compared to the no $\mathrm{N}$ addition level for gray and yellow birch, respectively. On the other hand, there was no effect of $\mathrm{N}$ addition on leaf area of red oak seedlings (Table 2.2). NAR increased with addition of 100 $\mathrm{kg} / \mathrm{ha} / \mathrm{yr} \mathrm{NH}_{4} \mathrm{NO}_{3}$ in gray and yellow birch seedlings but there was no additional stimulation with addition of $200 \mathrm{~kg} / \mathrm{ha} / \mathrm{yr} \mathrm{NH}_{4} \mathrm{NO}_{3}$ (Table 2.2). Furthermore, NAR of yellow birch was more responsive to increasing $\mathrm{N}$ availability than gray birch. NAR of yellow birch seedlings was $99 \%$ greater in the $100 \mathrm{~kg} / \mathrm{ha} / \mathrm{yr}$ treatment and $138 \%$ greater in the $200 \mathrm{~kg} / \mathrm{ha} / \mathrm{yr}$ treatment, compared to no $\mathrm{N}$ addition. NAR of gray birch seedlings was only $59 \%$ and $57 \%$ greater in the $100 \mathrm{~kg} / \mathrm{ha} / \mathrm{yr}$ and $200 \mathrm{~kg} / \mathrm{ha} / \mathrm{yr}$ treatments, respectively, compared to no N addition (Table 2.2). NAR of red oak seedlings was not responsive to $\mathrm{N}$ addition.

Relative growth rate of gray and yellow birch seedlings was stimulated by $\mathrm{N}$ addition, but RGR of red oak seedlings was not (Table 2.2). Relative growth rates of gray and yellow birch grown under $100 \mathrm{~kg} / \mathrm{ha} / \mathrm{yr} \mathrm{NH}_{4} \mathrm{NO}_{3}$ increased $38 \%$ and $80 \%$, respectively, compared to seedlings grown under no $\mathrm{N}$ addition, but neither was stimulated further with addition of $200 \mathrm{~kg} / \mathrm{ha} / \mathrm{yr}$ $\mathrm{NH}_{4} \mathrm{NO}_{3}$. The species-dependent response of RGR to $\mathrm{N}$ availability was due to changes in NAR, rather than LAR which was unaffected by N availability (Table 2.1). The effects of $\mathrm{N}$ addition on growth and biomass allocation were stronger than water availability, which did not significantly affect any parameter. I found no evidence for a main effect of water availability, Water x Species interaction, or N x Water x Species interaction on 
any parameter measured. However, a trend indicated that the effects of $\mathrm{N}$ on LMA depended on water availability ( $\mathrm{p}=0.07$; Table 2.1 ). This was due to the response of LMA in the no $\mathrm{N}$ addition treatments, where LMA of seedlings under augmented water availability was $12 \%$ and $14 \%$ lower than LMA of seedlings under ambient and reduced water conditions, respectively (Table 2.2).

There was also a trend to indicate that the effects of $\mathrm{N}$ on RGR depended on water availability ( $\mathrm{p}=0.07$; Fig. 2.6), such that stimulation of RGR by $\mathrm{N}$ addition was diminished under both reduced and augmented water conditions. Under ambient water conditions, RGR was stimulated by $81 \%$ and $88 \%$ with addition of $100 \mathrm{~kg} / \mathrm{ha} / \mathrm{yr}$ and $200 \mathrm{~kg} / \mathrm{ha} / \mathrm{yr} \mathrm{NH}_{4} \mathrm{NO}_{3}$, respectively, compared to the no $\mathrm{N}$ addition treatment. When water availability was reduced, however, RGR of seedlings exposed to $100 \mathrm{~kg} / \mathrm{ha} / \mathrm{yr}$ and $200 \mathrm{~kg} / \mathrm{ha} / \mathrm{yr} \mathrm{NH}_{4} \mathrm{NO}_{3}$ was only $38 \%$ and $50 \%$ greater, respectively, compared to the no $\mathrm{N}$ addition treatment. Under augmented water conditions, on the other hand, $\mathrm{N}$ addition had little effect on RGR (Fig. 2.6). 
Fig. 2.6. Relative growth rate of gray birch, yellow birch, and red oak seedlings grown with varying $\mathrm{N}$ and water availability. Standard error bars show $1 \mathrm{SE}+/-$ treatment means. Open bars are reduced water availability, hatched bars are ambient water availability, and closed bars are augmented water availability. 

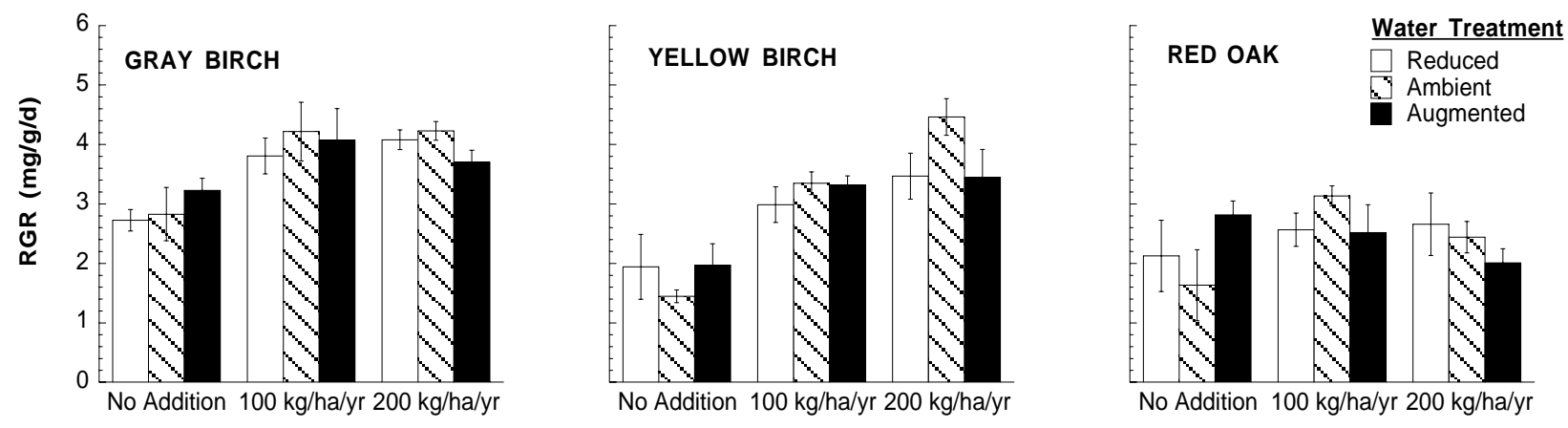

\section{Nitrogen Treatment}




\section{DISCUSSION}

Plant growth and allocation are strongly affected by the availability of multiple resources (Bloom et al. 1985; Chapin et al. 1987). An example of this is the integrated response of tree seedlings to elevated atmopsheric $\mathrm{N}$ deposition and variations in water availability, particularly drought (Raison et al. 1990; Rosengren-Brinck and Nihlgard 1995; DeVisser 1996). I hypothesized that $\mathrm{N}$ addition would stimulate foliar area and aboveground biomass production, at the expense of root production, and that this would adversely affect plant growth under reduced water conditions. Furthermore, forest tree response to elevated atmospheric $\mathrm{N}$ deposition has been shown to be species dependent (Berntson et al. 1995; Kinney and Lindroth 1997). Thus, I hypothesized that a faster growing, earlier successional species would be more responsive to $\mathrm{N}$ addition and more susceptible to water stress than slower growing, later successional species.

I found that $\mathrm{N}$ addition had strong effects on seedling biomass production. $\mathrm{N}$ addition stimulated total biomass production and RGR in seedlings of both birch species, but had no effect on growth of oak seedlings. Many studies have shown increased seedling growth with elevated N fertilization (Tschaplinski et al. 1991; Berntson et al. 1995; McConnaughay et al. 1996; Wendler and Millard 1996). Several other studies have shown reduced growth and regeneration of oak seedlings under high nitrogen and water supply, relative to faster growing, earlier successional species (Newton and Pigott 1991;Kinney and Lindroth 1997; Kruger and Reich 1997).

Contrary to my expectations, water availability had a very weak effect on seedling growth, despite evidence that water availability was successfully manipulated among treatments in the field (Fig. 2). However, I did find evidence of a trend that indicated, across all species, the 
$\mathrm{N}$-induced enhancement of RGR was diminished by approximately $40 \%$ under reduced water availability, compared to ambient water treatments. Furthermore, the N-induced stimulation of RGR was completely eliminated under augmented water availability, relative to the ambient water conditions. These results are consistent with other fertilization studies that have shown slower growth rates under reduced water conditions and attributed this response to the concomitant stimulation of transpirational area and reduction of root growth (DeVisser et al. 1996; Wendler and Millard 1996; Ibrahim et al. 1998). Walters and Reich (1996) showed that growth of deciduous seedlings failed to respond to $\mathrm{N}$ fertilization under well-watered conditions and attributed this lack of response to low light availability.

In the present study, $\mathrm{N}$ addition stimulated leaf area and NAR of birch seedlings, but had no effect on other measures of aboveground or belowground growth. Wendler and Millard (1996) showed that, although birch seedlings grew faster under high $\mathrm{N}$, stimulation of leaf area and NAR increased the potential for water loss in these seedlings.

This study supports my hypothesis that seedling response to $\mathrm{N}$ addition is species dependent, but the patterns we observed among species differing in life history traits do not follow my expectations. Although the slowest growing, stress-tolerant species (red oak) was the least responsive to $\mathrm{N}$ addition, I found that biomass production of the slower-growing birch species (yellow birch) was more than two-fold greater than the fast-growing, pioneer species (gray birch) under the highest N level. Berntson et al. (1995) also found that yellow birch seedlings were more responsive to elevated $\mathrm{N}$ than gray birch seedlings and showed that these two birch species exhibit different allocational strategies. Total biomass and leaf production, specific leaf area, and specific root length (within-organ parameters) were more sensitive to $\mathrm{N}$ fertilization in yellow birch than in gray birch. In gray birch, the magnitude of response to $\mathrm{N}$ 
addition was greater for between-organ parameters, such as the proportion of fine root mass to leaf mass and root length to leaf area. In my study, I found that stimulation of leaf area production and NAR by the highest level of $\mathrm{N}$ addition was approximately two times greater in yellow birch than in gray birch seedlings. However, I found no other evidence to indicate that patterns of biomass partitioning differ between these species as a function of elevated $\mathrm{N}$ or water availability. It may be that differential responses to elevated $\mathrm{N}$ between these two birch species are related to differences in biomass partitioning and to differences in photosynthetic response, which were not measured in this study.

Although I found no effect of $\mathrm{N}$ addition on root growth or R:S ratios in either birch species, these parameters were sensitive to $\mathrm{N}$ supply for red oak seedlings. In support of my hypothesis, that high $\mathrm{N}$ would reduce root growth, the highest $\mathrm{N}$ condition reduced RWR of red oak seedlings by $10 \%$ and reduced R:S ratios by $31 \%$, compared to conditions where no $\mathrm{N}$ was added. However, these differences were not sufficient to affect the overall growth of red oak seedlings. Red oak seedlings typically exhibit distinct periods of root and shoot growth (Reich et al. 1980), a character that could have contributed to the slower growth rates of this species in my field experiment. Emmett et al. (1995) showed that elevated sodium nitrate did not impact overall growth of Sitka spruce trees, but it reduced root biomass and, thereby, increased their susceptibility to drought.

Very few studies have examined the effects of elevated $\mathrm{N}$ and water availability on seedling growth in the field, and those that have focused primarily on the responses of coniferous species (Raison et al. 1990; DeVisser 1995; Rosengren-Brinck and Nihlgard 1995). An ongoing "Throughfall Displacement Experiment" (TDE) at the Walker Branch Watershed (Oak Ridge, TN) has been manipulating hydrologic inputs to a deciduous hardwood forest since 1993. 
Recent TDE reports have indicated that net root production in dry plots was several-fold higher than wet and ambient plots (Joslin and Wolfe 1998). However, they also found that these differences were not maintained below $30 \mathrm{~cm}$ in soils. Furthermore, they noted that it is unclear whether these differences were caused by a proliferation of new root production in response to a previous drought year, or actual adjustments in R:S ratios as a function of water treatments. Another TDE study reported that long term simulations with a nutrient cycling model predicted that reduced water inputs to this forest will not affect tree growth or ecosystem $\mathrm{N}$ status (Johnson et al. 1998). Like these TDE results, I found little evidence that our manipulations of water availability affected tree growth. When I harvested roots of seedlings in the present study, I found that root systems of all seedlings occupied soil depths well below $30 \mathrm{~cm}$ (T. S. Myers, personal observation). I conclude that, even though I consistently detected differences in soil water content among water availability treatments down to $15 \mathrm{~cm}$ (Fig. 2), water availability below this point may have been similar among treatments to influence seedling growth and biomass allocation. I did, however, observe increased leaf area production in birch seedlings and decreased RWR and R:S ratios in red oak seedlings under higher N levels. Given this, it is possible that if these seedlings were to experience a more severe drought period than the one that occurred in 1999, they may be more susceptible to symptoms of water stress.

In this study, seedlings of three deciduous tree species varied in their response to $\mathrm{N}$ addition. I found that birch species responded primarily through overall changes in growth and partioning to aboveground structures, whereas red oak seedlings invested more energy into belowground production, with little impact on overall growth rate. I found that as $\mathrm{N}$ addition increased, differences in seedling RGR between an early successional, faster growing species (gray birch) and a later successional, slower growing species (yellow birch) were diminished. 
RGR of gray birch seedlings was $64 \%$ greater than yellow birch seedlings in the unfertilized condition, $25 \%$ greater in the $100 \mathrm{~kg} / \mathrm{ha} / \mathrm{yr}$ condition, and only $8 \%$ greater than yellow birch under the highest level of $\mathrm{N}$ addition (Fig. 2.6). This pattern was due to a more pronounced increasee in RGR of yellow birch to $\mathrm{N}$ addition than gray birch. Furthermore, I found that differences in RGR between these two species were mostly due to changes in leaf area and NAR. I suggest that differences in growth between the two birch species may be influenced by differences in photosynthetic response to $\mathrm{N}$ addition. It also may be that other environmental factors, such as light availability, impact the effects of elevated $\mathrm{N}$ deposition on tree seedling growth, if not more so than water availability. 


\section{REFERENCES}

Aber, J.D., Nadelhoffer, K.J., Steudler, P., and Melillo. J.M. 1989. Nitrogen saturation in northern forest ecosystems. BioScience, 39: 378-386.

Aber, J.D., Magill, A., McNulty, S., Boone, R.D., Nadelhoffer, K.J., Downs, M., and Hallett, R. 1995. Forest biogeochemistry and primary production altered by nitrogen saturation. Water Air Soil Pollut. 85: 1665-1670.

Aber, J.D., McDowell, W., Nadelhoffer, K., Magill, A., Berntson, G., Kamakea, M., McNulty, S., Currie, W., Rustad, L., and Fernandez, I. 1998. Nitrogen saturation in temperate forest ecosystems. BioScience, 48: 921-934.

Berkowitz, A.R., Canham, C.D., and Kelly, V.R. 1995. Competition vs. facilitation of tree seedling growth and survival in early successional communitites. Ecology, 76: 11561168.

Berntson, G.M, Farnsworth, E.J., Bazzaz, F.A. 1995. Allocation, within and between organs, and the dynamics of root length canges in two birch species. Oecologia, 101: 439-447.

Bloom, A.J., Chapin, F.S., III, and Mooney, H.A. 1985. Resource limitation in plants-an economic analogy. Ann. Rev. Ecol. Syst. 16: 363-392.

Chapin, F. S., III, Bloom, A.J., Field, C.B., and Waring, R.H. 1987. Plant responses to multiple environmental factors. BioScience, 37: 49-57.

DeVisser, P.H.B. 1995. Effects of irrigation and balanced fertilization on nutrient cycling in a Douglas fir stand. Plant Soil, 168-169: 353-363.

DeVisser, P.H.B., Keltjens, W.G., Findenegg, G.R. 1996. Transpiration and drought resistance of Douglas-fir seedlings exposed to excess ammonium. 10: 301-307. 
Emmett, B.A., Brittain, S.A., Hughes, S., and Kennedy, V. 1995. Nitrogen additions $\left(\mathrm{NaNO}_{3}\right.$ and $\mathrm{NH}_{4} \mathrm{NO}_{3}$ ) at Aber forest, Wales: II. Response of trees and soil nitrogen transformations. 71: 61-73.

Fenn, M.E., Poth, M.A., Aber, J.D., Baron, J.S., Bormann, B.T., Johnson, D.W., Lemly, A.D., McNulty, S.G., Ryan, D.F., and Stottlemyer, R. 1998. Nitrogen excess in North American ecosystems: predisposing factors, ecosystem responses, and management strategies. Ecol. Appl. 8: 706-733.

Galloway, J.N. 1995. Acid deposition: perspectives in time and space. Water Air Soil Pollut. 85: $15-24$.

Gilliam, F.S., Adams, M.B., and Yurish, B.M. 1996. Ecosystem nutrient responses to chronic nitrogen inputs at Fernow Experimental Forest, West Virginia. Can. J. For. Res. 26: 196205.

Grime, J.P., and Hunt, R. 1975. Relative growth rate: its range and adaptive significance in local flora. J. Ecol. 63: 393-422.

Hallett, R.A. and Hornbeck, J.W. 1997. Foliar and soil nutrient relationships in red oak and white pine forests. Can. J. For. Res. 27: 1233-1244.

Huttl, R.F. 1990. Nutrient supply and fertilizaer experiments in view of N saturation. Plant and Soil, 128: 45-58.

Ibrahim, L., Proe, M.F., and Cameron, A.D. 1998. Interactive effects of nitrogen and water availabilities on gas exchange and whole-plant carbon allocation in poplar. Tree Physiol. 18: $481-487$. 
Johnson, D.W., Hanson, P.J., Todd, D.E., Susffalk, R.B., and Trettin, C.F. 1998. Precipitation change and soil leaching: field results and simulations from Walker Branch Watershed, Tennessee. Water Air Soil Pollut. 105: 251-262.

Joslin, J.D. and Wolfe, M.H. 1998. Impacts of water input manipulations on fine root production and mortality in a mature hardwood forest. Plant and Soil, 204: 165-174.

Kinney, K.K. and Lindroth, R.L. 1997. Responses of three deciduous tree species to atmospheric $\mathrm{CO}_{2}$ and soil $\mathrm{NO}_{3}{ }^{-}$availability. Can. J. For. Res. 27: 1-10.

Kruger, E.L. and Reich, P.B. 1997. Responses of hardwood regeneration to fire in mesic forest openings. II. Leaf gas exchange, nitrogen concentration, and water status. Can. J. For. Res. 27: 1832-1840.

Lippert, M., Haberle, KH., Steiner, K., Payer, HD., and Rehfuess, KE. 1996. Interactive effects of elevated $\mathrm{CO}_{2}$ and $\mathrm{O}_{3}$ on photosynthesis and biomass production of clonal 5-year-old Norway spruce [Picea aibes (L.) Karst.] under different nitrogen nutrition and irrigation treatments. Trees, 10: 382-392.

Liptzin, D. and Ashton, P.M.S. 1999. Early-successional dynamics of single-aged mixed hardwood stands in a southern New England forest, USA. For. Ecol. Manage. 116: 141150.

McDonald, A.J.S., Lohammar, T., and Ingestad, T. 1992. Net assimilation rate and shoot area development in birch (Betula pendula Roth.) at different steady-state values of nutrition and photon flux density. Trees, 6: 1-6.

McConnaughay, K.D.M., Nicotra, A.B., and Bazzaz, F.A. 1996. Rooting volume, nutrient availability, and $\mathrm{CO}_{2}$-induced growth enhancements in temperate forest tree seedlings. Ecol. Appl. 6: 619-627. 
McNulty, S.G., Aber, J.D., and Newman, S.D. 1996. Nitrogen saturation in a high elevation spruce-fir stand. For. Ecol. Manage. 85: 109-121.

Newton, A.C. and Pigott, C.D. 1991. Mineral nutrition and mycorrhizal infection of seedling oak and birch. II. The effect of fertilizers on growth, nutrient uptake and ectomycorrhizal infection. New Phytol. 117: 45-52.

Peterjohn, W.T., Foster, C.J., Christ, M.J., and Adams, M.B. 1999. Patterns of nitrogen availability within a forested watershed exhibiting symptoms of nitrogen saturation. For. Ecol. Manage. 119: 247-257.

Raison, R.J., Khanna, P.K, Connell, M.J., and Falkiner, R.A. 1990. Effects of water availability and fertilization on nitrogen cycling in a stand of Pinus radiata. For. Ecol. Manage. 30: $31-43$

Reich, P.B., Teskey, R.O., Hohnson, P.S., and Hinckley, T.M. 1980. Periodic root and shoot growth in oak. For. Sci. 26: 590-598.

Rosengren-Brinck, U. and Nihlgard, B. 1995. Effects of nutritional status on the drought resistance in Norway spruce. Water Air Soil Pollu. 85: 1739-1744.

Tschaplinski, T.J., Johnson, D.W., Norby, R.J., and Todd. D.E. 1991. Biomass and soil nitrogen relationships of a one-year-old sycamore plantation. Soil Sci. Soc. Am. J. 55: 841-847. Walters, M.B., and Reich, P.B. 1996. Are shade tolerance, survival, and growth linked? Low light and nitrogen effects on hardwood seedlings. Ecology, 77: 841-853.

Waring, R.H., McDonald, A.J.S., Larsson, S., Ericsson, T., Wiren, A., Arwidsson, Ericsson, A., and Lohammar, T. 1985. Differences in chemical composition of plants grown at constant relative growth rates with stable mineral nutrition. Oecologia, 66: 157-160. 
Wedin, D.A., and Tilman, D. 1996. Influence of nitrogen loading and species composition on the carbon balance of grasslands. Science, 274: 1720-1723.

Wendler, R. and Millard, P. 1996. Impacts of water and nitrogen supplies on the physiology, leaf demography, and nitrogen dynamics of Betula pendula. Tree Physiol. 16: 153-159.

Wright, E.L, Delp, C.H., Sponangle, K., Cole, C., Ammons, J.T., and Childs, F.D. 1982. Soil

Survey of Marion and Monongalia Counties, West Virginia. US Soil Conservation Service, Forest Service, and West Virginia Agricultural Experiment Station, Washington, DC. 


\section{Chapter 3}

The effects of $\mathrm{N}$ and water availability on leaf photosynthesis and photosynthetic resource-use efficiency of two birch species

under field conditions 


\section{ABSTRACT}

I tested the hypothesis that deciduous tree seedlings grown under elevated $\mathrm{N}$ availability would exhibit physiological symptoms of drought on leaf processes to a greater extent than seedlings grown under no $\mathrm{N}$ addition. I grew gray (Betula populifolia) and yellow birch (B.

alleghaniensis) seedlings in a field study for two years under varying levels of $\mathrm{N}$ and water availability and measured photosynthesis, as well as leaf properties. Contrary to my expectations, resource supply had a minimal effect on most leaf physiological measurements, but I did observe strong species differences. Gray birch seedlings had higher photosynthetic rates, water use efficiency $\left(\mathrm{P}_{\mathrm{WUE}}\right)$, photosynthetic nitrogen use efficiency $\left(\mathrm{P}_{\mathrm{NUE}}\right)$, photosynthetic capacity, LMA, leaf $\mathrm{N}$ and chlorophyll concentrations than yellow birch seedlings. Across both species, the maximum rate of electron transport $\left(\mathrm{J}_{\max }\right)$ was stimulated with $\mathrm{N}$ supply and only at the lowest level of $\mathrm{N}$ supplementation $\left(100 \mathrm{~kg} / \mathrm{ha} / \mathrm{yr} \mathrm{NH}_{4} \mathrm{NO}_{3}\right)$, implying a limit to the $\mathrm{N}$-induced stimulation of this parameter. Leaf water content (LWC) was the only leaf character sensitive to the interactive effects of $\mathrm{N}$ and water availability. Reductions in this parameter with decreasing water supply appeared to be moderated by $\mathrm{N}$ addition. I concluded that differences in species response, particularly in resource use efficiency, could impact seedling growth and, perhaps, competitive interactions in forests receiving elevated $\mathrm{N}$ deposition and variations in rainfall events. 


\section{INTRODUCTION}

Nitrogenous fertilizer use, fossil fuel burning, and the planting of leguminous species have doubled annual $\mathrm{N}$ deposition into terrestrial ecosystems (Vitousek 1997). Trees exposed to elevated $\mathrm{N}$ inputs experience increased shoot production and at times, reduced root production (Emmett et al. 1995; Lippert et al. 1996). When water is limiting concurrently with high $\mathrm{N}$ deposition, plants have a reduced ability to acquire water from the soil and, as a result, are more susceptible to drought injury (Osonubi and Davies 1981; Van der Eerden and Perez-Soba 1992; Ibrahim et al. 1998).

$\mathrm{N}$ fertilization stimulates leaf $\mathrm{N}$ concentration, which increases the production of enzymatic compounds used in photosynthesis. In this way, high $\mathrm{N}$ can increase photosynthetic water use efficiency $\left(\mathrm{P}_{\mathrm{wUE}}\right)$, the ratio of net photosynthetic rate to transpiration rate (Reich et al. 1989). $\mathrm{P}_{\mathrm{wUE}}$ can be temporarily improved during early stages of water stress when reductions in stomatal conductance reduce transpirational water loss and increase the $\mathrm{CO}_{2}$ concentration gradient across stomata, increasing photosynthetic rate (Lambers et al. 1998). However, if reductions in water supply become more severe, or if elevated $\mathrm{N}$ leads to soil acidification and reduced nutrient availability, stomatal closure, decreased nutrient and water uptake, and lower photosynthetic rates could decrease $P_{\text {wUE }}$.

Nitrogen availability can affect photosynthetic nitrogen use efficiency $\left(\mathrm{P}_{\mathrm{NUE}}\right)$, the ratio of net photosynthesis to leaf nitrogen content. Typically, $\mathrm{N}$ fertilized plants have higher foliar $\mathrm{N}$ concentration and, thus lower $\mathrm{P}_{\mathrm{NUE}}$ (Lajtha and Whitford 1989; Reich et al. 1989; Wang et al. 1998). It is also well documented that plants experience tradeoffs between $P_{\mathrm{wUE}}$ and $\mathrm{P}_{\mathrm{NUE}}$, 
whereby, under low water conditions, $\mathrm{P}_{\mathrm{wUE}}$ is maximized at the expense of $\mathrm{P}_{\mathrm{NUE}}$ (Field et al. 1983).

In this study, I determined how reductions in water availability affected carbon assimilation and resource use efficiency of two sympatric birch species grown under elevated $\mathrm{N}$ conditions. I examined instantaneous photosynthetic response $\left(\mathrm{A}_{\mathrm{net}}, \mathrm{g}_{\mathrm{s}}, \mathrm{P}_{\mathrm{WUE}}\right.$, and $\left.\mathrm{P}_{\mathrm{NUE}}\right)$, photosynthetic capacity, and foliar chemistry of gray (Betula populifolia Marsh) and yellow birch (B. alleghaniensis Britton) seedlings that differ in their life history traits (Burns and Honkala 1990). Gray birch is a fast growing, pioneer species that grows well on nutrient poor soils. Yellow birch is a slower growing, mid-successional species that requires higher soil fertility than gray birch. In a previous study, I showed that elevated $\mathrm{N}$ altered biomass production and allocation of gray and yellow birch seedlings in ways that potentially increased their susceptibility to drought injury, and these effects were more pronounced for yellow birch seedlings (Myers and Thomas, in preparation). However, I saw no effects of water availability on seedling growth, except for a slight reduction of the $\mathrm{N}$-induced enhancement of relative growth rates under low water conditions. In light of these results, I hypothesized that high $\mathrm{N}$ availability stimulates net photosynthetic rate. In addition, seedlings respond to reductions in water availability through stomatal adjustment, which impacts photosynthetic capacity, $\mathrm{P}_{\mathrm{WUE}}$ and $\mathrm{P}_{\mathrm{NUE}}$. 


\section{METHODS}

\section{Plant growth conditions}

Gray and yellow birch seedlings were grown for two years under $\mathrm{N}$ and water treatments at the WVU Agronomy Farm in Morgantown, West Virginia $\left(39^{\circ} 40^{\prime} \mathrm{N}, 79^{\circ} 54^{\prime} \mathrm{W}\right)$. Soils at this site are classified as moderately well-drained Dormont and Guernsey silt loams with 8 to 15 percent slopes and are described as highly suitable for tree growth (Wright et al. 1982).

Seeds of gray and yellow birch, collected from Pennsylvania sources (F.W. Schumacher Co., Inc., Sandwich, MA), were stratified for three months at $4^{\circ} \mathrm{C}$, germinated in May 1997, and grown for four months under greenhouse conditions $\left(29^{\circ} \mathrm{C}\right.$ day, $18^{\circ} \mathrm{C}$ night $)$.

In early October 1997, gray and yellow birch seedlings were transplanted at the WVU Agronomy Farm into nine blocks of three, $3 \times 2 \mathrm{~m}$ subplots, each containing five trees per species (Fig. 2.2). Within each subplot gray and yellow birch seedlings were planted together with red oak (Quercus rubra L.) and black locust seedlings (Robinia pseudoacacia L.), for a total of 20 seedlings planted in each subplot. Position of species within a subplot was randomly chosen and seedlings were planted $0.5 \mathrm{~m}$ apart. Time constraints and the interest in intrageneric differences limited the use to only gray and yellow birch species in this study. Nitrogen treatments included ambient and two levels of $\mathrm{N}$ fertilization. Fertilized blocks received a single application of dry $\mathrm{NH}_{4} \mathrm{NO}_{3}$ at levels of $100 \mathrm{~kg} / \mathrm{ha} / \mathrm{yr}(\mathrm{n}=3)$ and $200 \mathrm{~kg} / \mathrm{yr} / \mathrm{ha}(\mathrm{n}=3)$ at the beginning of March 1998 and March 1999. $\mathrm{NH}_{4} \mathrm{NO}_{3}$ was broadcast over the soil around the base of the seedlings (radius $=0.5 \mathrm{~m}$ ). $\mathrm{N}$ levels for supplemented plots approximate a high level of $\mathrm{N}$ deposition into some fertilized Appalachian forests (35 kg N/ha; Gilliam et al. 1996) and a 
doubled level (70 kg N/ha), given the future of increased $\mathrm{N}$ inputs to these systems (Galloway 1995). Three control blocks received no fertilizer addition.

Water availability to seedlings relied on natural rainfall events and was either reduced, ambient, or augmented. Water availability was reduced in nine, upslope subplots by capturing rainwater in open drainage pipes that covered approximately $25 \%$ of the subplot area. This water was diverted to nine, downslope, augmented subplots. A third set of nine supblots, flanked by the low and high-water subplots, served as an ambient condition. The ambient subplots had closed drainage pipes running through them, which did not alter the input of water from rainfall. Surface and subsurface water and nutrient flow was eliminated down to $3 \mathrm{~m}$ by plastic-lined trenches that separated the nine $\mathrm{N}$ treatment blocks from one another and the surrounding area. Soil water content was measured approximately weekly and precipitation and temperature were recorded daily throughout the growing seasons in 1998 and 1999 (Fig. 3.1). Differences among water treatments were maintained during the growing seasons by either the drainage pipe installation, the slightly-graded slope that the seedlings were planted on, or a combination of the two. Soil water content in reduced plots was lower than soil water content in augmented plots, throughout the two year period. The differences in soil water content between these water treatments ranged from below 5\% to about 10\%. Furthermore, during the 1999 growing season a drought occurred, as indicated by the overall lower precipitation and soil moisture values for that year. 
Fig. 3.1. Percent soil moisture and weekly precipitation for 1998 and 1999 growing seasons. Soil moisture was measured with TDR at a constant depth of $15 \mathrm{~cm}$ probes. Rainfall was measured using a rain gauge at the WVU Agronomy Farm. The x-axis is labeled by month, from June through October. The arrow marks the starting date when photosynthetic response was measured. 


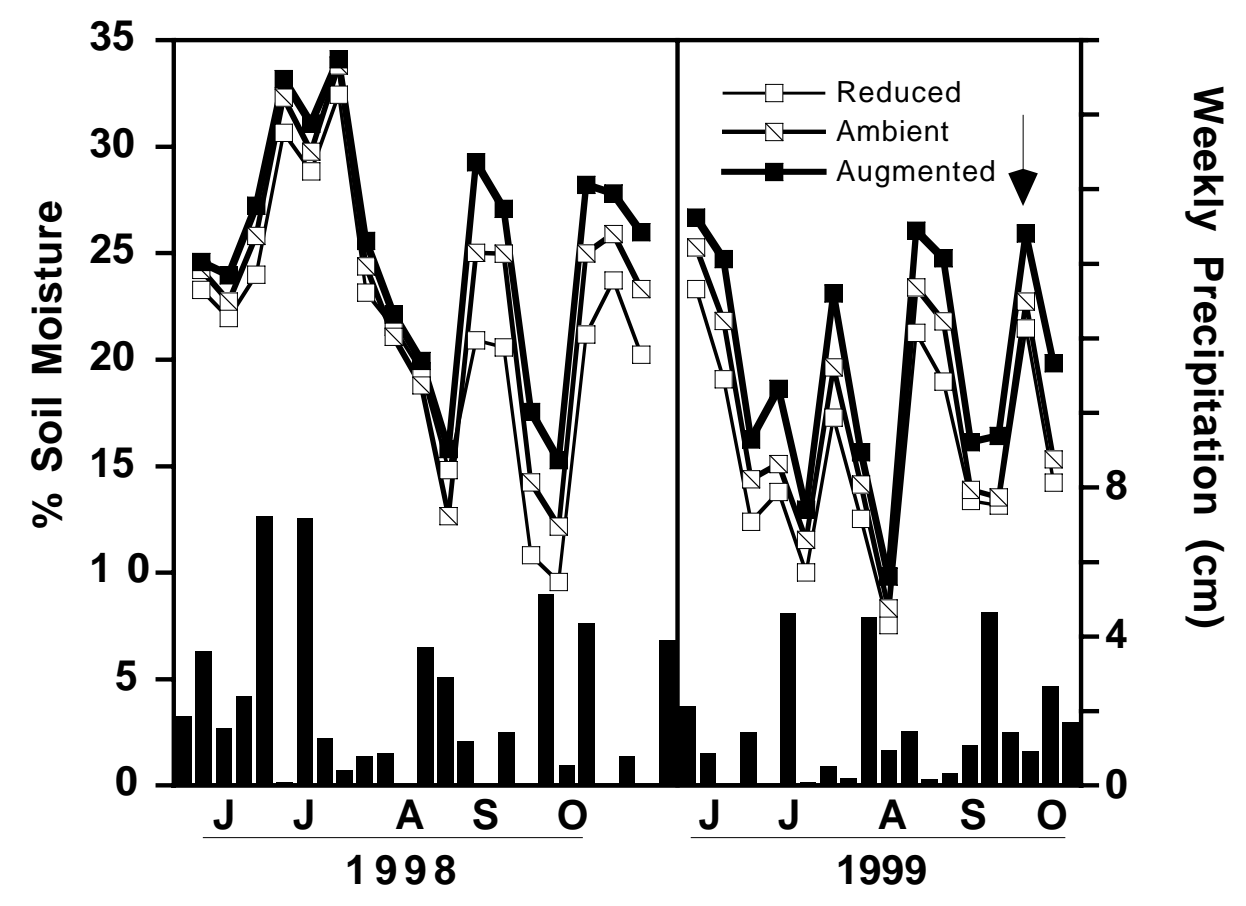

Fig. 3.1 


\section{Gas exchange measurements}

Measurements were made during the second week in September of 1999, to ensure that seedlings had experienced two full growing seasons under nitrogen and water treatments. Minimum air temperature during this week ranged from 10 to $19^{\circ} \mathrm{C}$ and maximum temperature ranged from 21 to $28^{\circ} \mathrm{C}$. Total rainfall during the week was $4.5 \mathrm{~cm}$ and soil moisture content averaged $21 \%$, $23 \%$, and $26 \%$ in reduced, ambient, and augmented water conditions, respectively (Fig. 3.1). The week before measurements were taken, soil moisture was much lower averaging 13\%, 14\%, and $16 \%$ in reduced, ambient, and augmented treatments.

Three seedlings were randomly selected from a pool of individuals within each Species $\mathrm{x}$ $\mathrm{N} \mathrm{x}$ Water treatment combination. Blocks within each nitrogen level were not considered during sampling, due to insufficient replication at this level. Net photosynthesis $\left(\mathrm{A}_{\text {net }}\right)$ and stomatal conductance $\left(\mathrm{g}_{\mathrm{s}}\right)$ were examined in situ on one leaf from each seedling within each $\mathrm{N} x$ Water $\mathrm{x}$ Species treatment combination. Measured leaves were fully-expanded and located at the distal end of the third branch from the top of each seedling. Measurements were made using an open flow infra-red gas analyzer with an attached LED light source (LI6400, Li-Cor, Inc. Lincoln, NE). Photosynthetic response to calculated intercellular $\mathrm{CO}_{2}\left(\mathrm{C}_{\mathrm{i}}\right)$ was measured over a range of 8 external $\mathrm{CO}_{2}$ partial pressures $\left(\mathrm{C}_{\mathrm{a}}\right)$ from approximately 50 to $1700 \mu 1^{-1}$ (Farquhar and Sharkey 1982). Measurements were made with a constant saturating irradiance of 1800 and $1600 \mu \mathrm{mol}$ $\mathrm{m}^{-2} \mathrm{~s}^{-1}$ photon flux density for gray and yellow birch, respectively. Gas exchange measurements were made at ambient relative humidity between 1000 and $1500 \mathrm{~h}$ on sunny days. Cuvette temperatures were kept constant during measurements at ambient air temperatures and averaged $31^{\circ} \mathrm{C} \pm 0.9^{\circ} \mathrm{C}$. The $\mathrm{A}-\mathrm{C}_{\mathrm{i}}$ curves were analyzed using a biochemically-based model (Farquhar et al. 1980) to determine the saturating rates of carboxylation $\left(\mathrm{Vc}_{\max }\right)$ and the electron transport- 
mediated rate of RuBP regeneration $\left(\mathrm{J}_{\max }\right)$ using the kinetic parameters of Wullshleger (1993). Net assimilation at growth $\mathrm{CO}_{2}\left(\mathrm{~A}_{\text {net }}\right)$ was obtained from $\mathrm{A}-\mathrm{C}_{\mathrm{i}}$ curves where $\mathrm{C}_{\mathrm{a}}$ equaled $350 \mu 1 \mathrm{l}^{-1}$. Net assimilation data obtained at a $\mathrm{C}_{\mathrm{i}}$ above $250 \mu \mathrm{ll}^{-1}$ were fitted to a second degree polynomial to estimate $\mathrm{A}_{\max }$, net assimilation under saturating light and $\mathrm{CO}_{2} \cdot \mathrm{P}_{\mathrm{wUE}}$ was calculated as the ratio of $\mathrm{A}_{\text {net }}$ to transpiration and $\mathrm{P}_{\mathrm{NUE}}$ as the ratio of $\mathrm{A}_{\text {net }}$ to leaf nitrogen content.

\section{Leaf properties}

On the day that seedling gas exchange was measured, pre-dawn leaf water potentials were also determined with a Scholander-type pressure chamber (PMS Instruments, Corvallis, OR). Immediately following gas exchange measurements, chlorophyll concentration was determined using a portable chlorophyll meter (SPAD-502, Minolta, Osaka, Japan) and readings were converted to chlorophyll concentrations using a standard curve obtained with chlorophyll extracted from a subset of leaves using N, N-dimethylformamide (Porra et al. 1989). Each leaf and two, fully expanded proximal leaves were harvested from each seedling and transported to the lab on ice, where leaf area and fresh weight of each sample were determined. Leaf samples were dried at $65^{\circ} \mathrm{C}$ to a constant mass and leaf mass per unit area (LMA) and leaf water content (LWC) were determined. LWC was calculated as the proportional difference between fresh and dry weight of each leaf sample. Leaf samples were ground in a Tecator Cyclotec Sample Mill (Tecator, Höganäs, Sweden) to assay nitrogen and carbohydrate concentration. Leaf nitrogen was measured with a Carlo Erba CNS elemental analyzer (Fisons Instr., Milan, Italy). Leaf starch and soluble sugar concentrations were assayed spectrophotometrically using an acid hydrolysis method (Tissue and Wright 1995). 


\section{Statistical analysis}

Gas exchange measurements and leaf properties were analyzed using three way ANOVAs to test for the effects of species, nitrogen availability, water supply, and their interactions. Post-hoc comparisons of treatment means were conducted with Tukey-Kramer HSD tests, using an alpha $=0.05$. Data were pooled across treatment groups for each species and analysis of covariance (ANCOVA) and least squares linear regression were used to analyze the relationships between $A_{\text {net }}$ and $g_{s}, A_{\text {net }}$ and leaf nitrogen concentration $\left(N_{A}\right), V c_{\max }$ and $\left(N_{A}\right)$, and $J_{\max }$ and $\left(N_{A}\right)$. Correlation coefficients were determined for the relationship between $\mathrm{P}_{\mathrm{wUE}}$ and $\mathrm{P}_{\mathrm{NUE}}$ for gray and yellow birch species, as well. 


\section{RESULTS}

\section{Net photosynthesis and stomatal conductance}

There were species differences for $\mathrm{A}_{\text {net }}$ and $\mathrm{g}_{\mathrm{s}}$ (Table 3.1). Net photosynthesis and $\mathrm{g}_{\mathrm{s}}$ of gray birch seedlings were $70 \%$ and $73 \%$ greater than yellow birch seedlings (Fig. 3.2). There were no effects of $\mathrm{N}$, water availability, or their interaction on $\mathrm{A}_{\text {net }}$ or $\mathrm{g}_{\mathrm{s}}$ (Table 3.1).

\section{Photosynthetic capacity}

The maximum rate of carboxylation $\left(\mathrm{Vc}_{\max }\right)$ and the maximum rate of electron transport $\left(\mathrm{J}_{\max }\right)$, two potential biochemical limitations to photosynthesis, were modeled from $A-C_{\mathrm{i}}$ curves represented in Fig. 3.3. Averaged across $\mathrm{N}$ and water treatments, gray birch leaves had higher $\mathrm{Vc}_{\max }(57 \%), \mathrm{J}_{\max }(74 \%)$, and $\mathrm{A}_{\max }(82 \%)$ than yellow birch leaves (Table 3.2). $\mathrm{J}_{\max }$ was significantly different across $\mathrm{N}$ treatments (Table 3.2). Leaves from seedlings exposed to 100 $\mathrm{kg} / \mathrm{ha} / \mathrm{yr} \mathrm{NH}_{4} \mathrm{NO}_{3}$ had the highest $\mathrm{J}_{\max }$, which was $32 \%$ greater than $\mathrm{J}_{\max }$ of leaves grown under no $\mathrm{N}$ addition and $20 \%$ greater than that of leaves grown under $200 \mathrm{~kg} / \mathrm{ha} / \mathrm{yr} \mathrm{NH}_{4} \mathrm{NO}_{3} . \mathrm{Vc}_{\max }, \mathrm{A}_{\max }$, and the ratio of $\mathrm{J}_{\max }$ to $\mathrm{Vc}_{\max }$ did not differ as a function of nitrogen, water availability, or their interactions (Table 3.2).

\section{Leaf properties}

I found significant differences between species for many leaf properties (Table 3.3). Averaged across $\mathrm{N}$ and water treatments, leaf water potential (LWP) of yellow birch seedlings was $23 \%$ lower (more negative) than gray birch seedlings (Table 3.4). Gray birch seedlings had higher 
Table 3.1. $F$ statistics for main treatment effects and their interactions on $\mathrm{A}_{\text {net }}$ (net photosynthesis at growth $\mathrm{CO}_{2}$ ), $\mathrm{g}_{\mathrm{s}}$ (stomatal conductance), $\mathrm{P}_{\mathrm{wUE}}$ (photosynthetic water use efficiency), and $\mathrm{P}_{\mathrm{NUE}}$ (photosynthetic nitrogen use efficiency) of gray and yellow birch seedlings grown under varying $\mathrm{N}$ and water availability. Asterisks refer to the probability of a greater $F$ statistic calculated for the full factorial design: $*=0.01<P \leq 0.05 ; * *=0.001<P \leq 0.01 ; * * * P \leq 0.001$.

\begin{tabular}{|c|c|c|c|c|c|c|c|}
\hline Variable & Species & $\mathrm{N}$ & Water & Sp x N & Sp x Water & $\mathrm{Nx}$ Water & Sp x N x Water \\
\hline $\begin{array}{l}\mathrm{A}_{\text {net }} \\
\left(\mu \mathrm{mol} \mathrm{CO} \mathrm{CO}^{-2} \mathrm{~s}^{-1}\right)\end{array}$ & $25.53 * * *$ & 0.42 & 0.69 & 0.98 & 0.75 & 0.81 & 0.31 \\
\hline $\begin{array}{l}\mathrm{g}_{\mathrm{s}} \\
\left(\mathrm{mol} \mathrm{m} \mathrm{s}^{-2}\right)\end{array}$ & $12.76 * * *$ & 1.49 & 2.64 & 1.85 & 0.38 & 0.43 & 1.45 \\
\hline $\begin{array}{l}\mathrm{P}_{\mathrm{WUE}} \\
\left(\mu \mathrm{mol} \mathrm{CO} \mathrm{mol}^{-1} \mathrm{H}_{2} \mathrm{O}\right)\end{array}$ & $10.87 * *$ & 0.19 & 2.93 & 0.27 & 1.45 & 0.41 & 0.39 \\
\hline $\begin{array}{l}\mathrm{P}_{\mathrm{NUE}} \\
\left(\mu \mathrm{mol} \mathrm{CO} \mathrm{g}^{-1} \mathrm{~N} \mathrm{~s}^{-1}\right)\end{array}$ & $9.44 * *$ & $10.16^{* * * *}$ & 2.14 & $5.98 * *$ & 2.09 & $3.16^{*}$ & 2.36 \\
\hline
\end{tabular}


Fig. 3.2. Net photosynthetic rate $\left(\mathrm{A}_{\text {net }}\right)$ and stomatal conductance $\left(\mathrm{g}_{\mathrm{s}}\right)$ of gray and yellow birch seedlings grown under varying levels of $\mathrm{N}$ and water supply. Standard error bars show $1 \mathrm{SE} \pm$ treatment means. Open bars are reduced water treatment, hatched bars are ambient water treatment, and closed bars are augmented water treatment. 

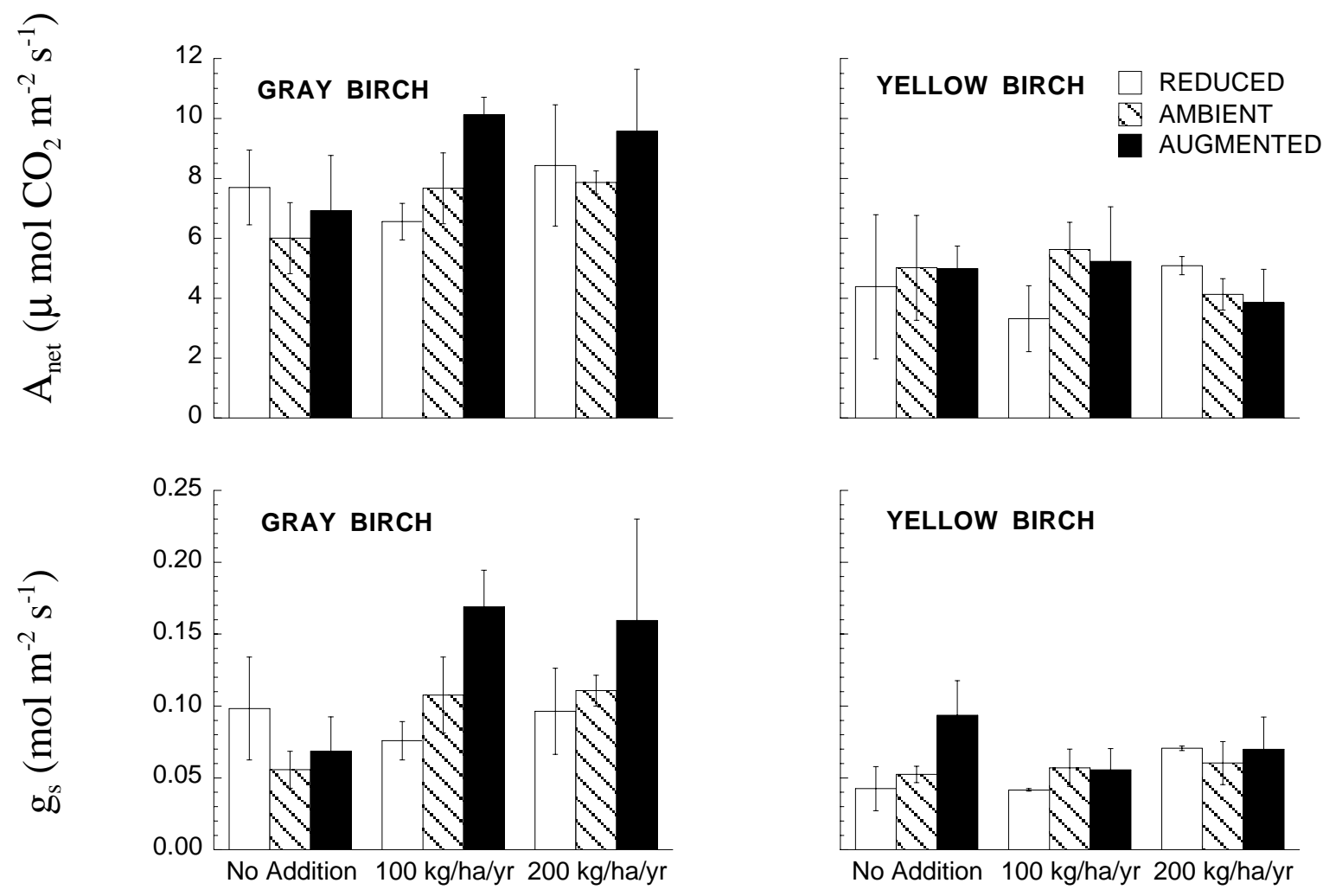

Nitrogen Treatment

Fig. 3.2 
Fig. 3.3. Representative A- $\mathrm{C}_{\mathrm{i}}$ curves of gray and yellow birch seedlings grown under varying levels of $\mathrm{N}$ and water supply. Open circles are reduced water treatment. Closed triangles are ambient water treatment. Closed circles are augmented water treatment. 


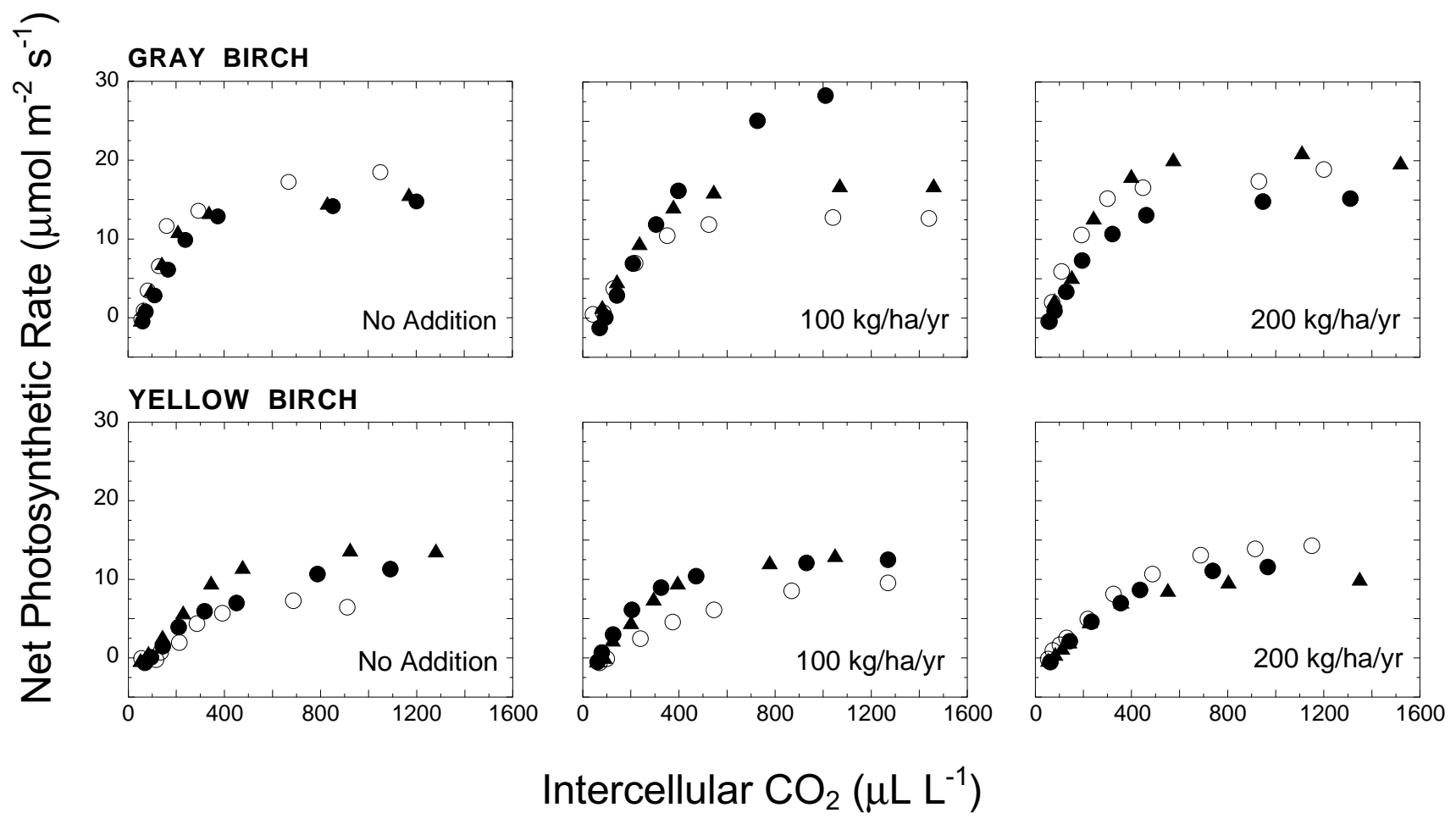

Fig. 3.3 
Table 3.2. $F$ Statistics for main treatment effects and their interactions on $\mathrm{Vc}_{\max }$ (maximum velocity of carboxylation), $\mathrm{J}_{\max }$ (maximum electron transport), the ratio of $\mathrm{J}_{\max }$ to $\mathrm{Vc}_{\max }$, and $\mathrm{A}_{\max }$ (net photosynthetic rate at $\mathrm{CO}_{2}$ saturation) of gray and yellow birch seedlings grown under varying $\mathrm{N}$ and water availability. Asterisks refer to the probability of a greater $F$ statistic calculated for the full factorial design: * $=0.01<P$ $\leq 0.05 ; * *=0.001<P \leq 0.01 ; * * * P \leq 0.001$.

\begin{tabular}{llllllll}
\hline Variable & Species & $\mathrm{N}$ & Water & $\mathrm{Sp} \mathrm{x} \mathrm{N}$ & Sp x Water & $\mathrm{N}$ x Water & Sp x N x Water \\
\hline $\begin{array}{l}\mathrm{Vc}_{\max } \\
\left(\mu \mathrm{mol} \mathrm{CO} \mathrm{m}^{-2} \mathrm{~s}^{-1}\right)\end{array}$ & $5.95^{*}$ & 0.06 & 0.20 & 1.02 & 0.84 & 0.47 & 0.31 \\
$\mathrm{~J}_{\max }$ & $37.91^{* * *}$ & $3.54^{*}$ & 1.24 & 2.21 & 0.33 & 2.34 & 0.35 \\
$\left(\mu \mathrm{mol} \mathrm{CO} \mathrm{m}^{-2} \mathrm{~s}^{-1}\right)$ & & & & & & & \\
$\mathrm{J}_{\max } / \mathrm{Vc}_{\max }$ & 2.19 & 0.31 & 0.82 & 0.03 & 0.91 & 0.59 & 0.44 \\
$\mathrm{~A}_{\max }$ & $23.86^{* * *}$ & 0.82 & 1.05 & 2.16 & 1.11 & 0.75 & 0.15 \\
\hline$\left.\mu \mathrm{mol} \mathrm{CO} \mathrm{m}^{-2} \mathrm{~s}^{-1}\right)$ & & & & & & & \\
\hline
\end{tabular}


Table 3.3. $F$ statistics for main treatment effects and their interactions on foliar characters of gray and yellow birch seedlings grown under varying $\mathrm{N}$ and water availability. Asterisks refer to the probability of a greater $F$ statistic calculated for the full factorial design: $*=0.01<P \leq 0.05$; ** $=0.001<P \leq 0.01$; *** $P \leq 0.001$.

\begin{tabular}{lccccccc}
\hline Variable & Species & $\mathrm{N}$ & Water & Sp x N & Sp x Water & N x Water & Sp x N x Water \\
\hline LWP $(\mathrm{MPa})$ & $5.83^{*}$ & 0.94 & 0.36 & 2.68 & 0.65 & 0.77 & 1.19 \\
LMA $\left(\mathrm{g} \mathrm{m}^{-2}\right)$ & $28.18^{* * *}$ & 0.08 & 1.21 & $3.78^{*}$ & 0.90 & 2.30 & 0.48 \\
LWC $(\%)$ & $12.20^{* *}$ & 1.46 & $6.66^{* *}$ & $3.52^{*}$ & 0.09 & $3.60^{*}$ & 0.09 \\
$\mathrm{~N}_{\mathrm{M}}\left(\mathrm{mg} \mathrm{g}^{-1}\right)$ & $6.12^{*}$ & 0.92 & 0.24 & 0.28 & 0.56 & 1.54 & 0.56 \\
$\mathrm{~N}_{\mathrm{A}}\left(\mathrm{g} \mathrm{m}^{-2}\right)$ & $31.27^{* * *}$ & 0.66 & 0.13 & 0.57 & 0.57 & 0.40 & 0.61 \\
$\mathrm{Chl}_{\mathrm{M}}\left(\mathrm{mg} \mathrm{g}^{-1}\right)$ & 2.26 & 0.26 & 0.63 & 0.26 & 1.64 & 0.42 & 0.92 \\
$\mathrm{Chl}_{\mathrm{A}}\left(\mathrm{g} \mathrm{m}^{-2}\right)$ & $6.41^{*}$ & 2.34 & 0.01 & 1.22 & 3.23 & 0.61 & 0.08 \\
${\text { Sugar }\left(\mathrm{mg} \mathrm{g}^{-1}\right)}^{0.31}$ & 0.32 & 0.18 & 1.17 & 0.32 & 0.50 & 0.50 \\
Starch $\left(\mathrm{mg} \mathrm{g}^{-1}\right)$ & 0.01 & 1.90 & 0.24 & 0.59 & 0.93 & 1.04 & 1.20 \\
\hline
\end{tabular}


Table 3.4. Leaf characters of gray and yellow birch seedlings grown under varying levels of $\mathrm{N}$ and water availability. Values are means $( \pm \mathrm{SE}), \mathrm{n}=3$. $\mathrm{N}$ treatments are no $\mathrm{N}$ addition (No), $100 \mathrm{~kg} / \mathrm{ha} / \mathrm{yr} \mathrm{NH}_{4} \mathrm{NO}_{3}$ (100), and $200 \mathrm{~kg} / \mathrm{ha} / \mathrm{yr} \mathrm{NH} \mathrm{NO}_{3}$ (200). Water treatments are reduced (Red), ambient (Amb), and augmented (Aug).

\begin{tabular}{|c|c|c|c|c|c|c|c|c|c|c|}
\hline $\begin{array}{l}\text { Leaf } \\
\text { character }\end{array}$ & Species & No/Red & $\mathrm{No} / \mathrm{Amb}$ & No/Aug & 100/Red & $100 / \mathrm{Amb}$ & 100/Aug & 200/Red & 200/Amb & 200/Aug \\
\hline $\begin{array}{l}\text { LWP } \\
(\mathrm{MPa})\end{array}$ & $\begin{array}{l}\text { gray birch } \\
\text { yellow birch }\end{array}$ & $\begin{array}{l}-3.8 \pm 0.8 \\
-5.3 \pm 0.9\end{array}$ & $\begin{array}{l}-5.6 \pm 0.2 \\
-3.8 \pm 0.3\end{array}$ & $\begin{array}{l}-6.1 \pm 0.7 \\
-5.4 \pm 0.6\end{array}$ & $\begin{array}{l}-4.1 \pm 0.1 \\
-5.2 \pm 0.2\end{array}$ & $\begin{array}{l}-3.4 \pm 1.5 \\
-6.7 \pm 0.9\end{array}$ & $\begin{array}{l}-2.9 \pm 1.1 \\
-5.4 \pm 1.2\end{array}$ & $\begin{array}{l}-3.9 \pm 1.5 \\
-7.1 \pm 1.4\end{array}$ & $\begin{array}{l}-4.2 \pm 1.2 \\
-5.4 \pm 0.4\end{array}$ & $\begin{array}{l}-5.9 \pm 0.1 \\
-6.1 \pm 1.5\end{array}$ \\
\hline $\begin{array}{l}\text { LMA } \\
\left(\mathrm{g} \mathrm{m}^{-2}\right)\end{array}$ & $\begin{array}{l}\text { gray birch } \\
\text { yellow birch }\end{array}$ & $\begin{array}{l}78.7 \pm 2.1 \\
73.0 \pm 2.7\end{array}$ & $\begin{array}{r}73.2 \pm 0.7 \\
78.5 \pm 11.6\end{array}$ & $\begin{array}{l}68.8 \pm 1.5 \\
58.1 \pm 3.6\end{array}$ & $\begin{array}{l}75.4 \pm 5.3 \\
65.3 \pm 5.1\end{array}$ & $\begin{array}{l}77.5 \pm 3.3 \\
63.3 \pm 6.4\end{array}$ & $\begin{array}{l}78.6 \pm 4.8 \\
63.7 \pm 4.7\end{array}$ & $\begin{array}{l}81.6 \pm 2.7 \\
65.7 \pm 3.3\end{array}$ & $\begin{array}{l}75.5 \pm 3.7 \\
58.3 \pm 5.7\end{array}$ & $\begin{array}{l}83.6 \pm 3.8 \\
62.0 \pm 5.1\end{array}$ \\
\hline $\begin{array}{l}\text { LWC } \\
(\%)\end{array}$ & $\begin{array}{l}\text { gray birch } \\
\text { yellow birch }\end{array}$ & $\begin{array}{l}53.4 \pm 0.6 \\
48.9 \pm 1.3\end{array}$ & $\begin{array}{l}55.2 \pm 0.7 \\
50.4 \pm 3.0\end{array}$ & $\begin{array}{l}60.0 \pm 1.8 \\
54.3 \pm 0.8\end{array}$ & $\begin{array}{l}54.2 \pm 0.7 \\
51.4 \pm 0.3\end{array}$ & $\begin{array}{l}57.1 \pm 0.7 \\
55.5 \pm 1.3\end{array}$ & $\begin{array}{l}56.7 \pm 2.3 \\
55.4 \pm 1.9\end{array}$ & $\begin{array}{l}54.4 \pm 1.7 \\
53.4 \pm 1.3\end{array}$ & $\begin{array}{l}56.4 \pm 1.0 \\
56.4 \pm 1.0\end{array}$ & $\begin{array}{l}53.7 \pm 1.0 \\
53.2 \pm 2.1\end{array}$ \\
\hline $\begin{array}{l}\mathrm{N}_{\mathrm{M}} \\
\left(\mathrm{mg} \mathrm{g}^{-1}\right)\end{array}$ & $\begin{array}{l}\text { gray birch } \\
\text { yellow birch }\end{array}$ & $\begin{array}{l}23.0 \pm 1.6 \\
18.3 \pm 4.0\end{array}$ & $\begin{array}{l}21.0 \pm 0.4 \\
18.7 \pm 1.5\end{array}$ & $\begin{array}{l}25.5 \pm 1.9 \\
21.8 \pm 1.5\end{array}$ & $\begin{array}{l}24.2 \pm 1.5 \\
18.3 \pm 1.5\end{array}$ & $\begin{array}{l}23.7 \pm 0.6 \\
23.4 \pm 3.0\end{array}$ & $\begin{array}{l}22.3 \pm 1.0 \\
22.3 \pm 2.1\end{array}$ & $\begin{array}{l}23.8 \pm 2.3 \\
23.0 \pm 2.4\end{array}$ & $\begin{array}{l}24.9 \pm 1.7 \\
23.8 \pm 3.4\end{array}$ & $\begin{array}{l}23.2 \pm 1.7 \\
19.5 \pm 3.2\end{array}$ \\
\hline $\begin{array}{l}\mathrm{N}_{\mathrm{A}} \\
\left(\mathrm{g} \mathrm{m}^{-2}\right)\end{array}$ & $\begin{array}{l}\text { gray birch } \\
\text { yellow birch }\end{array}$ & $\begin{array}{l}1.8 \pm 0.1 \\
1.3 \pm 0.3\end{array}$ & $\begin{array}{l}1.5 \pm 0.1 \\
1.4 \pm 0.1\end{array}$ & $\begin{array}{l}1.8 \pm 0.1 \\
1.3 \pm 0.1\end{array}$ & $\begin{array}{l}1.8 \pm 0.2 \\
1.2 \pm 0.1\end{array}$ & $\begin{array}{l}1.8 \pm 0.1 \\
1.5 \pm 0.2\end{array}$ & $\begin{array}{l}1.8 \pm 0.2 \\
1.4 \pm 0.2\end{array}$ & $\begin{array}{l}1.9 \pm 0.2 \\
1.5 \pm 0.1\end{array}$ & $\begin{array}{l}1.9 \pm 0.2 \\
1.4 \pm 0.1\end{array}$ & $\begin{array}{l}1.9 \pm 0.2 \\
1.2 \pm 0.2\end{array}$ \\
\hline $\begin{array}{l}\mathrm{Chl}_{\mathrm{M}} \\
\left(\mathrm{mg} \mathrm{g}^{-1}\right)\end{array}$ & $\begin{array}{l}\text { gray birch } \\
\text { yellow birch }\end{array}$ & $\begin{array}{l}6.7 \pm 0.2 \\
5.6 \pm 1.1\end{array}$ & $\begin{array}{l}5.9 \pm 0.3 \\
7.2 \pm 1.4\end{array}$ & $\begin{array}{l}6.9 \pm 1.2 \\
7.6 \pm 0.2\end{array}$ & $\begin{array}{l}6.9 \pm 0.4 \\
7.6 \pm 1.5\end{array}$ & $\begin{array}{l}6.4 \pm 0.8 \\
9.0 \pm 1.0\end{array}$ & $\begin{array}{l}6.1 \pm 0.8 \\
7.2 \pm 0.3\end{array}$ & $\begin{array}{l}6.1 \pm 0.1 \\
6.3 \pm 0.1\end{array}$ & $\begin{array}{l}6.1 \pm 0.7 \\
9.3 \pm 2.7\end{array}$ & $\begin{array}{l}7.0 \pm 1.9 \\
6.5 \pm 1.6\end{array}$ \\
\hline $\begin{array}{l}\mathrm{Chl}_{\mathrm{A}} \\
\left(\mathrm{g} \mathrm{m}^{-2}\right)\end{array}$ & $\begin{array}{l}\text { gray birch } \\
\text { yellow birch }\end{array}$ & $\begin{array}{l}0.12 \pm 0.01 \\
0.09 \pm 0.02\end{array}$ & $\begin{array}{l}0.10 \pm 0.01 \\
0.10 \pm 0.02\end{array}$ & $\begin{array}{l}0.12 \pm 0.01 \\
0.09 \pm 0.01\end{array}$ & $\begin{array}{l}0.19 \pm 0.02 \\
0.10 \pm 0.01\end{array}$ & $\begin{array}{l}0.11 \pm 0.01 \\
0.13 \pm 0.01\end{array}$ & $\begin{array}{l}0.12 \pm 0.01 \\
0.12 \pm 0.01\end{array}$ & $\begin{array}{l}0.13 \pm 0.01 \\
0.11 \pm 0.01\end{array}$ & $\begin{array}{l}0.11 \pm 0.01 \\
0.12 \pm 0.01\end{array}$ & $\begin{array}{l}0.12 \pm 0.01 \\
0.10 \pm 0.01\end{array}$ \\
\hline $\begin{array}{l}\text { Sugar } \\
\left(\mathrm{mg} \mathrm{g}^{-1}\right)\end{array}$ & $\begin{array}{l}\text { gray birch } \\
\text { yellow birch }\end{array}$ & $\begin{array}{l}0.12 \pm 0.02 \\
0.15 \pm 0.02\end{array}$ & $\begin{array}{l}0.12 \pm 0.01 \\
0.14 \pm 0.02\end{array}$ & $\begin{array}{l}0.11 \pm 0.01 \\
0.14 \pm 0.02\end{array}$ & $\begin{array}{l}0.13 \pm 0.01 \\
0.15 \pm 0.03\end{array}$ & $\begin{array}{l}0.14 \pm 0.02 \\
0.11 \pm 0.03\end{array}$ & $\begin{array}{l}0.11 \pm 0.01 \\
0.12 \pm 0.03\end{array}$ & $\begin{array}{l}0.13 \pm 0.02 \\
0.10 \pm 0.02\end{array}$ & $\begin{array}{l}0.12 \pm 0.02 \\
0.12 \pm 0.02\end{array}$ & $\begin{array}{l}0.13 \pm 0.01 \\
0.13 \pm 0.02\end{array}$ \\
\hline $\begin{array}{l}\text { Starch } \\
\left(\mathrm{mg} \mathrm{g}^{-1}\right)\end{array}$ & $\begin{array}{l}\text { gray birch } \\
\text { yellow birch }\end{array}$ & $\begin{array}{l}0.14 \pm 0.01 \\
0.14 \pm 0.01\end{array}$ & $\begin{array}{l}0.18 \pm 0.02 \\
0.18 \pm 0.01\end{array}$ & $\begin{array}{l}0.19 \pm 0.03 \\
0.14 \pm 0.01\end{array}$ & $\begin{array}{l}0.16 \pm 0.02 \\
0.22 \pm 0.04\end{array}$ & $\begin{array}{l}0.20 \pm 0.02 \\
0.17 \pm 0.04\end{array}$ & $\begin{array}{l}0.18 \pm 0.02 \\
0.16 \pm 0.03\end{array}$ & $\begin{array}{l}0.16 \pm 0.03 \\
0.16 \pm 0.03\end{array}$ & $\begin{array}{l}0.15 \pm 0.02 \\
0.15 \pm 0.01\end{array}$ & $\begin{array}{l}0.15 \pm 0.01 \\
0.18 \pm 0.03\end{array}$ \\
\hline
\end{tabular}


LMA (18\%) and LWC (4\%) than yellow birch seedlings. Leaf $\mathrm{N}$ concentration of gray birch was $11 \%$ and $33 \%$ greater than yellow birch on a leaf mass and area basis, respectively (Table 3.4). Chlorophyll concentration of gray birch was $10 \%$ greater than yellow birch, but only on a leaf area basis. Carbohydrate concentration did not significantly differ between species (Table $3.3)$.

There were no main effects of $\mathrm{N}$ availability on leaf properties, but the effects of nitrogen on LMA differed between species (Table 3.3). As nitrogen availability to seedlings increased, differences in LMA between species increased. Under no $\mathrm{N}$ addition, LMA did not differ between species. As $100 \mathrm{~kg} / \mathrm{ha} / \mathrm{yr}$ and $200 \mathrm{~kg} / \mathrm{ha} / \mathrm{yr} \mathrm{NH}_{4} \mathrm{NO}_{3}$ were added, LMA of gray birch seedlings were $20 \%$ and $29 \%$ greater than yellow birch seedlings (Table 3.4). The effects of $\mathrm{N}$ on LWC was also species dependent (Table 3.3). Under no N addition, LWC of gray birch foliage was 9\% greater than yellow birch, whereas LWC did not differ between species in Nfertilized treatments.

The only leaf property significantly affected by water supply was LWC (Table 3.3). Averaged across species and $\mathrm{N}$ treatments, leaves from reduced water conditions had the lowest water content (Table 3.4). The effects of $\mathrm{N}$ on LWC depended on seedling water supply (Table 3.3). Under no $\mathrm{N}$ addition, $\mathrm{LWC}$ increased $11 \%$ as water availability increased from reduced to augmented. In conditions where $\mathrm{N}$ fertilizer was added, LWC was similar across water treatments. 


\section{Photosynthetic water and nitrogen use efficiencies}

Overall, gray birch seedlings had $36 \%$ greater $\mathrm{P}_{\mathrm{WUE}}$ and $44 \%$ greater $\mathrm{P}_{\mathrm{NUE}}$ than yellow birch seedlings (Fig. 3.4). Nitrogen and water availability did not significantly affect $\mathrm{P}_{\mathrm{WUE}}$ or $\mathrm{P}_{\mathrm{NUE}}$. $\mathrm{P}_{\mathrm{WUE}}$ and $\mathrm{P}_{\mathrm{NUE}}$ were significantly and positively correlated in gray birch seedlings $(r=0.46, \mathrm{p}=$ 0.02). In yellow birch seedlings these parameters were not significantly correlated $(r=-0.11, \mathrm{p}$ $=0.57)$.

\section{Relationships between photosynthetic responses and leaf $\mathbf{N}$}

Pooling data across $\mathrm{N}$ and water treatments revealed a positive relationship between $\mathrm{A}$ and $\mathrm{g}_{\mathrm{s}}$ for gray and yellow birch seedlings (Table 3.5). For gray birch seedlings, the coefficient of determination $\left(r^{2}\right)$ indicated that more than four-fifths of the variation in $\mathrm{A}_{\text {net }}$ was accounted for by changes in $\mathrm{g}_{\mathrm{s}}$. Analysis of covariance, however, indicated that the slopes of gray birch and yellow birch seedlings did not differ for the relationship between $A_{\text {net }}$ and $g_{s}$. There was no evidence for a significant relationship between $A_{\text {net }}$ and $N_{A}$ (Table 3.5). There was a positive relationship between $\mathrm{Vc}_{\max }$ and $\mathrm{N}_{\mathrm{A}}$ for yellow birch seedlings (Table 3.5), where $18 \%$ of the variation in $\mathrm{Vc}_{\max }$ was associated with the variation in leaf $\mathrm{N}$. I found no evidence for any relationships between photosynthetic parameters and $\mathrm{N}_{\mathrm{A}}$ in gray birch seedlings, including no relationships between $\mathrm{J}_{\max }$ and $\mathrm{N}_{\mathrm{A}}$ for either birch species. 
Fig. 3.4. Photosynthetic water use efficiency $\left(\mathrm{P}_{\mathrm{wUE}}\right)$ and phtosynthetic nitrogen use efficiency $\left(\mathrm{P}_{\mathrm{NUE}}\right)$ for gray and yellow birch seedlings grown under varying levels of $\mathrm{N}$ and water supply. Standard error bars show $1 \mathrm{SE} \pm$ treatment means. Open bars are reduced water treatment, hatched bars are ambient water treatment, and closed bars are augmented water treatment. 


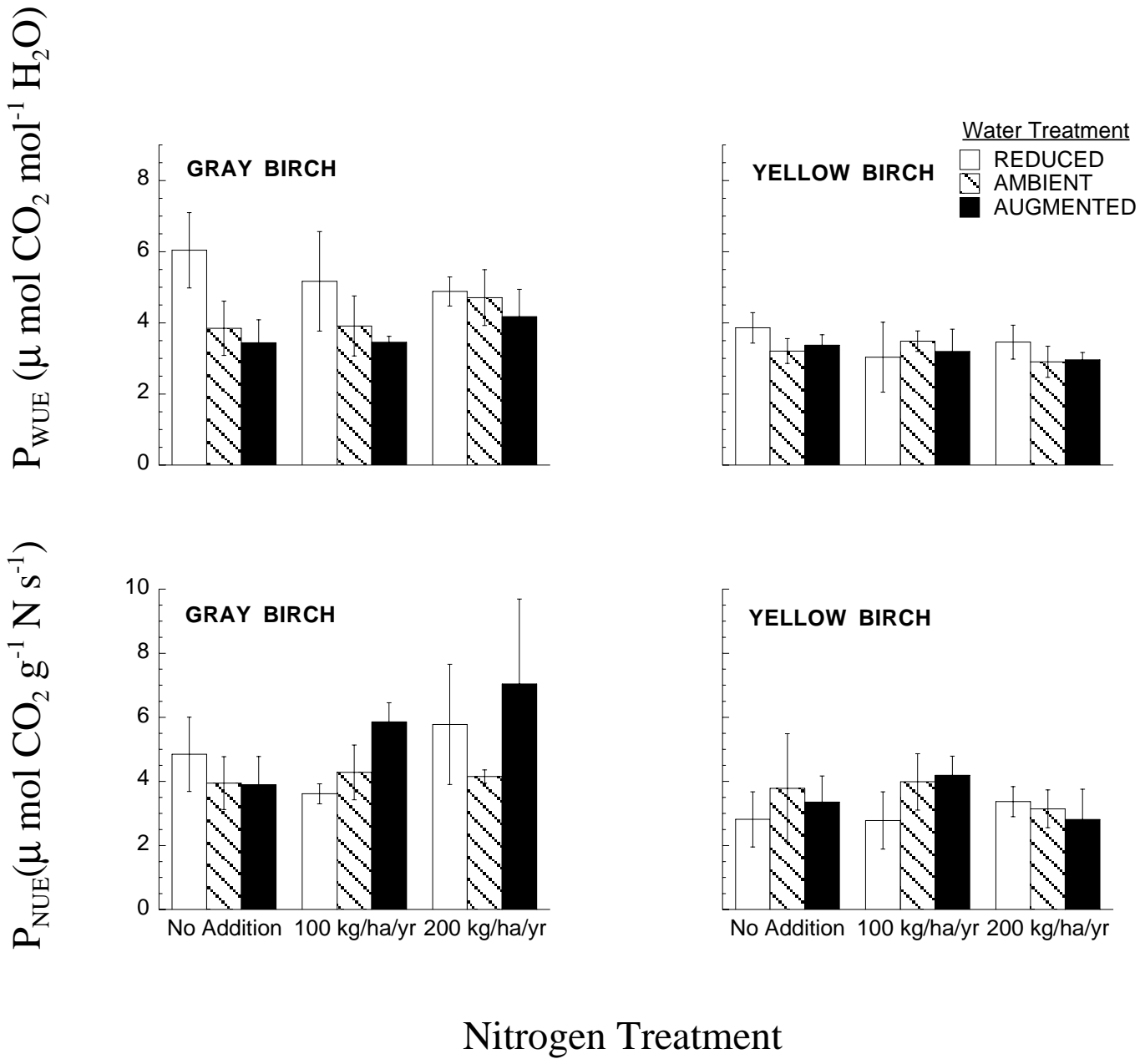

Fig. 3.4 
Table 3.5. Relationships between $\mathrm{A}_{\text {net }}$ (net photosynthetic rate) and $\mathrm{g}_{\mathrm{s}}$ (stomatal conductance), $\mathrm{A}_{\text {net }}$ and leaf $\mathrm{N}$ on an area basis $\left(\mathrm{N}_{\mathrm{A}}\right), \mathrm{Vc}_{\max }$ (maximum rate of carboxylation) and $\mathrm{N}_{\mathrm{A}}, \mathrm{J}_{\max }$ (maximum rate of electron transport) and $\mathrm{N}_{\mathrm{A}}$ for gray and yellow birch seedlings. Species data were pooled across $\mathrm{N}$ and water treatments.

\begin{tabular}{|c|c|c|c|c|}
\hline Relationship & Species Regression Equation & $F$ & $\mathrm{P}>F$ & $r^{2}$ \\
\hline$A_{\text {net }}$ vs $g_{s}$ & $\begin{aligned} \text { gray birch } & \mathrm{A}_{\text {net }}=4.1372+35.6058 \mathrm{~g}_{\mathrm{s}} \\
\text { yellow birch } & \mathrm{A}_{\text {net }}=1.7791+47.1172 \mathrm{~g}_{\mathrm{s}}\end{aligned}$ & $\begin{array}{r}118.02 \\
13.89\end{array}$ & $\begin{array}{r}<0.001 \\
0.001\end{array}$ & $\begin{array}{l}0.81 \\
0.36\end{array}$ \\
\hline$A_{\text {net }}$ vs $N_{A}$ & $\begin{aligned} \text { gray birch } & \mathrm{A}_{\text {net }}=10.5051-1.52324 \mathrm{~N}_{\mathrm{A}} \\
\text { yellow birch } & \mathrm{A}_{\text {net }}=1.37661+2.3211 \mathrm{~N}_{\mathrm{A}}\end{aligned}$ & $\begin{array}{l}1.27 \\
3.66\end{array}$ & $\begin{array}{l}0.271 \\
0.068\end{array}$ & $\begin{array}{l}0.05 \\
0.13\end{array}$ \\
\hline $\mathrm{Vc}_{\max } \operatorname{Vs} \mathrm{N}_{\mathrm{A}}$ & 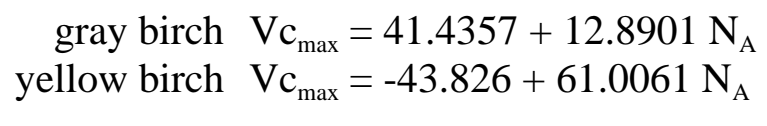 & $\begin{array}{l}0.95 \\
4.99\end{array}$ & $\begin{array}{l}0.341 \\
0.036\end{array}$ & $\begin{array}{l}0.04 \\
0.18\end{array}$ \\
\hline $\mathrm{J}_{\max } \mathrm{Vs} \mathrm{N}_{\mathrm{A}}$ & $\begin{aligned} \text { gray birch } & J_{\max }=56.9571+30.1512 \mathrm{~N}_{\mathrm{A}} \\
\text { yellow birch } & \mathrm{J}_{\max }=31.6718+22.2957 \mathrm{~N}_{\mathrm{A}}\end{aligned}$ & $\begin{array}{l}2.08 \\
2.24\end{array}$ & $\begin{array}{l}0.162 \\
0.149\end{array}$ & $\begin{array}{l}0.08 \\
0.09\end{array}$ \\
\hline
\end{tabular}




\section{DISCUSSION}

Elevated $\mathrm{N}$ can alter tree growth in ways that increase the potential for transpirational water loss and reduced water uptake (Van der Eerden and Perez-Soba 1992, Emmett et al. 1995, De Visser et al. 1996). In a previous study, I examined the effects of varying $\mathrm{N}$ and water availability on deciduous tree seedling growth and biomass allocation (Myers and Thomas in preparation). I observed increased leaf area production in gray and yellow birch species and reduced root growth in red oak species with $\mathrm{N}$ addition. However, I observed no negative effects of reduced water availability on seedling growth. I hypothesized that if any adverse effects of water stress were conferred to seedlings grown under elevated $\mathrm{N}$ conditions, they may be more apparent at the leaf level, manifest through changes in photosynthetic response and resource use efficiency.

In the present study, I found strong species differences in photosynthetic response. Others have also noted that early successional species, such as gray birch, exhibit higher photosynthetic rates than later successional species, like yellow birch (Abrams and Mostoller 1995; Bazzaz 1996). I found few effects of $\mathrm{N}$ supply and no effects of water supply on carbon assimilation and resource use efficiency by gray and yellow birch seedlings and, thus, little evidence to support my hypothesis. I found no effect of elevated $\mathrm{N}$ availability on $\mathrm{A}_{\text {net }}$ in gray or yellow birch seedlings. Other studies have examined photosynthetic response of different birch species and, similarly, found no differences in $A_{\text {net }}$ due to N supply (Wendler and Millard 1996, Wang et al. 1998). However, unlike our findings, these studies found that seedling response to water supply was strongly dependent on $\mathrm{N}$ availability. Wendler and Millard (1996) found that under low N, $\mathrm{A}_{\text {net }}$ and transpirational water loss of Betula pendula leaves were unaffected by differences in water availability, whereas both of these parameters decreased when water 
availability was reduced to seedlings grown under high nitrogen. However, at the whole canopy level, they found that seedlings grown under high $\mathrm{N}$ experienced greater transpirational water loss, due to greater leaf production and leaf area.

In the present study, I observed no significant differences in LWP across water treatments, which may have been the reason that water supply had no effect on $A_{\text {net }}$ or $g_{s}$. Wang et al. (1998) examined instantaneous photosynthetic response in four populations of paper birch. Contrary to my study, they found reductions in $\mathrm{g}_{\mathrm{s}}$ with decreased water supply and, under high water conditions, two populations showed reduced $\mathrm{g}_{\mathrm{s}}$ with increased $\mathrm{N}$ availability.

The results of my study do not support the results of others that have examined the interactive effects of nitrogen and water availability on photosynthetic response and resource use efficiency (Lajtha and Whitford 1989, Reich et al. 1989, Wang et al. 1998). In addition to the parameters already mentioned, I found no effects of $\mathrm{N}$ and water availability on $\mathrm{P}_{\mathrm{WUE}}$ or $\mathrm{P}_{\mathrm{NUE}}$, as well as no evidence of a correlation between $\mathrm{P}_{\mathrm{WUE}}$ and $\mathrm{P}_{\mathrm{NUE}}$. I found a positive relationship between $\mathrm{A}_{\text {net }}$ and $\mathrm{g}_{\mathrm{s}}$, and these strongly covaried in gray birch seedlings (Table 3.5). Overall, gray birch seedlings exhibited higher photosynthetic rates and stomatal conductance, greater $\mathrm{P}_{\mathrm{WUE}}, \mathrm{P}_{\mathrm{NUE}}$, and photosynthetic capacity than yellow birch seedlings. I expected gray birch to exceed yellow birch across these parameters, given the low resource requirements of gray birch and their relatively faster growth rates.

Several studies have shown positive relationships between photosynthesis and leaf $\mathrm{N}$ (Lathja and Whitford 1989; Johnsen 1993; Abrams and Mostoller 1995; Reich et al. 1998). In my study, the lower level of $\mathrm{N}$ addition $\left(100 \mathrm{~kg} / \mathrm{ha} / \mathrm{yr} \mathrm{NH}_{4} \mathrm{NO}_{3}\right)$ stimulated $\mathrm{J}_{\max }$, while $\mathrm{J}_{\max }$ of leaves at the higher $\mathrm{N}$ level $\left(200 \mathrm{~kg} / \mathrm{ha} / \mathrm{yr} \mathrm{NH}_{4} \mathrm{NO}_{3}\right)$ did not differ from the no $\mathrm{N}$ addition treatment. This implies that there is a $\mathrm{N}$-induced limitation to the stimulation of maximum 
electron transport rates for these birch species. I found no differences in the $\mathrm{J}_{\max }$ to $\mathrm{Vc}_{\max }$ ratio across species or resource supply, indicating the similarity with which species regulate photosynthetic capacity between carboxylation and electron transport rates, independent of resource supply. I also found no differences in foliar N, chlorophyll, or total nonstructural carbohydrate concentrations across $\mathrm{N}$ and water treatments. Gray birch seedlings had greater LMA, foliar $\mathrm{N}$ and chlorophyll concentration than yellow birch, as I expected given their higher photosynthetic response. Abrams and Mostoller (1995) also showed that early successional species had greater LMA and leaf $\mathrm{N}$ content than later successional species and suggested that greater LMA contributed to greater drought tolerance by early successional species.

Despite finding no differences in pre-dawn LWP across water treatments, I found that across species and $\mathrm{N}$ treatments, LWC decreased with reductions in water availability. Furthermore, I found that yellow birch leaves had lower LWC with more negative pre-dawn LWP than gray birch leaves. Pre-dawn LWP of seedlings from all Species $x \mathrm{~N} x$ Water treatment groups were well below those reported for other deciduous tree seedlings in a field study where water was manipulated in a similar manner to my study (Tschaplinski et al. 1998). The low pre-dawn LWP values in my study are evidence of the drought that seedlings were experiencing during 1999 and also imply that yellow birch seedlings were experiencing greater water stress than gray birch seedlings, although I found no other physiological evidence to support this. Under no $\mathrm{N}$ addition, LWC decreased with reduced water supply and this did not change with water availability under $\mathrm{N}$-fertilized treatments. This was the only leaf character that appeared to be sensitive to a $\mathrm{N}$-induced moderation of water stress symptoms.

Several studies have suggested that elevated $\mathrm{N}$ alters the drought resistance of plants (Nilsen 1995, De Visser et al. 1996). Van der Eerden and Perez-Soba (1992) showed that Pinus 
sylvestris saplings fumigated with atmospheric ammonia experienced increased photosynthesis and transpiration, greater water loss and, greater susceptibility to drought. I observed minimal responses of seedling photosynthesis, resource use efficiency, and leaf chemistry to variations in water supply under elevated $\mathrm{N}$. I found high variability of seedling response in my field study. The majority of studies that showed strong responses of physiological parameters to variations in resource supply had greater experimental control, either in pot studies or chamber environments (Reich et al. 1989, Van der Eerden and Perez-Soba 1992, Wendler and Millard 1996, De Visser et al. 1996, Wang et al. 1998). Johnsen (1993) showed that $\mathrm{N}$-fertilized black spruce seedlings exposed to elevated $\mathrm{CO}_{2}$ showed a strong positive relationship between photosynthetic rate and foliar $\mathrm{N}$ concentration in well-watered plants, but not in droughted plants. In a field study, Lajtha and Whitford (1989) showed a relationship between net photosynthesis and leaf $\mathrm{N}$ in Larrea tridentata plants exposed to $\mathrm{N}$ fertilization and variations in water availability, but this relationship was inconsistent across months. The interactive effects of water availability on plants grown under elevated $\mathrm{N}$ environments remain unclear, yet $\mathrm{N}$ inputs into forest ecosystems continue at an accelerated rate (Fenn et a. 1998). It is essential to understand the impact of these environmental effects on physiological mechanisms that differentially determine the growth of tree species, as this could affect competitive interactions and larger-scale dynamics, such as changes in forest species composition. 


\section{REFERENCES}

Abrams, M.D. and S.A. Mostoller. 1995. Gas exchange, leaf structure and nitrogen in contrasting successional tree species growing in open understory sites during a drought. Tree Physiol. 15:361-370.

Bazzaz, F.A. 1996. Physiological trends of successional plants. In Plants in Changing Environments. Cambridge University Press, Cambridge, pp 206-222.

Burns, R.M. and B.H. Honkala. 1990. Silvics of North America, vol 2. Hardwoods. USDA, Washington.

DeVisser, P.H.B., W.G. Keltjens and G.R. Findenegg. 1996. Transpiration and drought resistance of Douglas-fir seedlings exposed to excess ammonium. Trees 10:301-307.

Emmett, B.A., S.A. Brittain, S. Hughes and V. Kennedy. 1995. Nitrogen additions $\left(\mathrm{NaNO}_{3}\right.$ and $\mathrm{NH}_{4} \mathrm{NO}_{3}$ ) at Aber forest, Wales: II. Response of trees and soil nitrogen transformations. For. Ecol. Manage. 71:61-73.

Farquhar, G.D., S. von Caemmerer and J.A. Berry. 1980. A biochemical model of photosynthetic $\mathrm{CO}_{2}$ assimilation in leaves of $\mathrm{C}_{3}$ species. Planta 149:78-90.

Farquhar, G.D. and T.D. Sharkey. 1982. Stomatal conductance and photosynthesis. Ann. Rev. Plant Physiol. 33:317-345.

Fenn, M.E., M.A. Poth, J.D. Aber, J.S. Baron, B.T. Bormann, D.W. Johnson, A.D., Lemly, S.G. McNulty, D.F. Ryan and R. Stottlemyer. 1998. Nitrogen excess in North American ecosystems: predisposing factors, ecosystem responses, and management strategies. Ecol. Appl. 8:706-733. 
Field, C., J. Merino and H.A. Mooney. 1983. Compromises between water-use efficiency and nitrogen-use efficiency in five species of California evergreens. Oecologia 60:384-389.

Field, C. and H.A. Mooney. 1986. The photosynthesis-nitrogen relationship in wild plants. In On the Economy of Plant Form and Function. Ed. T.J. Givnish. Cambridge University Press, Cambridge, UK., pp25-55.

Galloway, J.N. 1995. Acid deposition: perspectives in time and space. Water Air Soil Pollut. 85:15-24.

Gilliam, F.S., M.B. Adams and B.M. Yurish. 1996. Ecosystem nutrient responses to chronic nitrogen inputs at Fernow Experimental Forest, West Virginia. Can. J. For. Res. 26:196-205.

Ibrahim, L., M.F. Proe and A.D. Cameron. 1998. Interactive effects of nitrogen and water availabilities on gas exchange and whole-plant carbon allocation in poplar. Tree Physiol. $18: 481-487$.

Johnsen, K.H. 1993. Growth and ecophysiological responses of black spruce seedlings to elevated $\mathrm{CO}_{2}$ under varied water and nutrient additions. Can. J. For. Res. 23:1033-1042.

Kramer, P.J. and J.S. Boyer. 1995. Stomata and gas exchange. In Water Relations in Plants and Soils. Academic Press, Inc., San Diego, pp 257-282.

Lajtha, K. and W.G. Whitford. 1989. The effect of water and nitrogen amendments on photosynthesis, leaf demography, and resource-use efficiency in Larrea tridentata, a desert evergreen shrub. Oecologia 80:341-348.

Lambers, H., F.S. Chapin III, and T.L. Pons. 1998. Photosynthesis, respiration, and long-distance transport. In Plant Physiological Ecology. Springer-Verlag, New York, pp 10-153. 
Lippert, M., K.H. Häberle, K. Steiner, H.D. Payer and K.E. Rehfuess. 1996. Interactive effects of elevated $\mathrm{CO}_{2}$ and $\mathrm{O}_{3}$ on photosynthesis and biomass production of clonal 5-year-old Norway spruce [Picea abies (L.) Karst.] under different nitrogen nutrition and irrigation treatments. Trees 10:382-392.

Myers, T.S. and R.B. Thomas. Effects of water availability on growth and biomass allocation of three deciduous tree species exposed to elevated $\mathrm{N}$ deposition in a field study. In preparation.

Nilsen, P. 1995. Effect of nitrogen on drought strain and nutrient uptake in Norway spruce Picea abies (L.) Karst.) trees. Plant and Soil 172:73-85.

Osonubi, O. and W.J. Davies. 1981. Root growth and water relations in oak and birch seedlings. Oecologia 51:343-350.

Porra, R.J., W.A. Thompson and P.E. Kriedemann. 1989. Determination of accurate extinction coefficients and simultaneous equations for assaying chlorophylls $a$ and $b$ extracted with four different solvents: verification of the concentration of chlorophyll standards by atomic absorption spectroscopy. Biochim. Biophys. Acta. 975:384-394.

Reich, P.B., M.B. Walters and T.J. Tabone. 1989. Response of Ulmus americana seedlings to varying nitrogen and water status. 2. Water and nitrogen use efficiency in photosynthesis. Tree Physiol. 5:173-184.

Reich, P.B., M.B. Walters, M.G. Tjoelker, D.Vanderklein, and C. Buschena. 1998. Photosynthesis and respiration rates depend on leaf and root morphology and nitrogen concentration in nine boreal tree species differing in relative growth rate. Funct. Ecol. 12:395-405. 
Tissue, D.T. and S.J. Wright. 1995. Effect of seasonal water availability on phenology and the annual shoot carbohydrate cycle of tropical forest shrubs. Funct. Ecol. 9:518-527.

Tschaplinski, T.J., G.M. Gebre and T.L. Shirshac. 1998. Osmotic potential of several hardwood species as affected by manipulation of throughfall precipitation in an upland oak forest during a dry year. Tree Physiol. 18:291-298.

Van der Eerden, L.J.M. and M.G.F.J. Perez-Soba. 1992. Physiological responses of Pinus sylvestris to atmospheric ammonia. Trees 6:48-53.

Vitousek, P.M., J.D. Aber, R.W. Howarth, G.E. Likens, P.A. Matson, D.W. Schindler, W.H. Schlesinger and D.G. Tilman. 1997a. Human alteration of the global nitrogen cycle: sources and consequences. Ecol. Appl. 7:737-750.

Wang, J.R., C.D.B. Hawkins and T. Letchford. 1998. Photosynthesis, water and nitrogen use efficiencies of four paper birch (Betula papyrifera) populations grown under different soil moisture and nutrient regimes. For. Ecol. Manage. 112:233-244.

Wendler, R. and P. Millard. 1996. Impacts of water and nitrogen supplies on the physiology, leaf demography and nitrogen dynamics of Betula pendula. Tree Physiol. 16:153-159.

Wright, E.L, C.H. Delp, K. Sponangle, C. Cole, J.T. Ammons and F.D. Childs.1982. Soil Survey of Marion and Monongalia Counties, West Virginia. US Soil Conservation Service, Forest Service, and West Virginia Agricultural Experiment Station, Washington, DC.

Wullschleger, S.D. 1993. Biochemical limitations to carbon assimilation in $\mathrm{C}_{3}$ plants- a retrospective analysis of the A/Ci curves from 109 species. J. Exp. Bot. 44:907-920. 


\section{Chapter 4}

Impacts of $\mathbf{N}$ and water availability on seedling foliar chemistry of differently-suitable host species and gypsy moth performance 


\section{ABSTRACT}

Northeastern forests of North America receive excessive $\mathrm{N}$ inputs and global climate change models predict that these regions will experience increases in the occurrence and severity of drought. I hypothesized that the interaction of these factors would alter foliar chemistry of trees in ways that would increase the susceptibility of these forests to insect herbivory by gypsy moth, a generalist herbivore. I grew seedlings of two host species, gray birch (Betula populifolia) and yellow birch (B. alleghaniensis), in the field for two years under three levels of elevated $\mathrm{NH}_{4} \mathrm{NO}_{3}$ (no addition, $100 \mathrm{~kg} / \mathrm{ha} / \mathrm{yr}, 200 \mathrm{~kg} / \mathrm{ha} / \mathrm{yr}$ ) and three levels of water availability (reduced, ambient, augmented). During the second year, I quantified foliar chemistry and fed late-instar gypsy moth larvae foliage from these seedlings in growth chamber feeding trials and quantified insect response. Gray birch and yellow birch differed in many leaf characteristics, including specific leaf area (SLA), leaf water content (LWC), C/N ratio, sugar concentration, condensed tannin concentration, sugar/condensed tannin ratio, and nitrogen concentration. As a result, gray birch produced more nutritive foliage and gypsy moth performed better on this species. Addition of $\mathrm{N}$ at $100 \mathrm{~kg} / \mathrm{ha} / \mathrm{yr} \mathrm{NH}_{4} \mathrm{NO}_{3}$ stimulated foliar $\mathrm{N}$ in both species and chlorophyll concentration in gray birch. Reductions in water availability increased sugar/condensed tannin ratios in both species. The response of herbivory to $\mathrm{N}$ and water availability, however, was unpredictable and nonlinear, such that increasing levels of $\mathrm{N}$ did not directly increase growth rates and nutritional indices. I conclude that any species-dependent effects of nitrogen and water availability that may alter competitive interactions and, perhaps shifts in species composition, will more likely influence forest susceptibility to defoliation by gypsy moth than the effects of $\mathrm{N}$ and water availability on foliar chemistry. 


\section{INTRODUCTION}

Elevated atmospheric nitrogen deposition in forests of northeastern North America alters tree response in ways that can affect many aspects of ecosystem dynamics, including species composition, nutrient cycling, and the performance of phytophagous insects (Aber et al. 1998;

Erelli et al. 1998; Fenn et al. 1998). Nitrogen fertilization studies have shown that trees exposed to elevated $\mathrm{N}$ inputs initially exhibit increased growth and reduced carbohydrate storage, while producing high $\mathrm{N}$ foliage with relatively lower concentrations of carbon-containing compounds (Estiarte et al. 1994; Hoft et al. 1996). These studies provide strong support for the carbonnutrient balance (CNB) hypothesis, which states that plants not limited by $\mathrm{N}$ produce leaves with low $\mathrm{C} / \mathrm{N}$ ratios (Bryant et al. 1983). Because insect performance is directly related to foliar $\mathrm{N}$ concentration (Mattson 1980), elevated $\mathrm{N}$ inputs could greatly increase forest susceptibility to insect outbreaks by improving the performance of insects on trees in these forests.

Multiple environmental factors affect plant resource supply, foliar $\mathrm{N}$ content and, thus, foliar quality to insect herbivores (e.g. Chapin et al. 1987; Thomas and Hodkinson 1991; Estiarte et al. 1994; Höft et al. 1996; Roth et al. 1997). For example, many studies have shown that plants grown under elevated atmospheric $\mathrm{CO}_{2}$ produce foliage with high $\mathrm{C} / \mathrm{N}$ ratios, which reduces larval growth rates, development rates, pupal weights, and survival of insect herbivores (Wong 1979; Lindroth et al. 1993; Roth and Lindroth 1994; Traw et al. 1996; Kinney et al. 1997; Williams et al. 1997; Bezemer and Jones 1998; Coley 1998; Hättenschwiler and Schafellner 1999). Despite poorer insect performance, larvae may exhibit higher consumption rates when feeding on lower quality foliage (Slansky and Wheeler 1992). The effect of water availability on 
foliar chemistry, however, is variable and its role in plant-insect interactions is less clear (Mattson and Haack 1987; English-Loeb et al. 1997).

The plant-stress hypothesis maintains that low water availability alters leaf chemistry in ways that promote insect outbreaks. According to this hypothesis, soluble $\mathrm{N}$ concentration in leaves increase within moderately water-stressed plants and severely water-stressed plants lack the resources to produce metabolically expensive defensive compounds, many of which are carbon-based (Rhodes 1979; Gershenzon 1984; White 1984). Recent studies, however, have documented nonlinear responses of plants and insect herbivores to increasing water stress, finding little evidence for the broad relationships proposed by the plant-stress hypothesis (Thomas and Hodkinson 1991; Floater 1997; Shure et al. 1998). Because global climate change models forecast increased occurrence of drought in some terrestrial ecosystems concurrently experiencing elevated $\mathrm{N}$ deposition (Wetherald and Manabe 1999), it is important to determine the effects of water availability, its interaction with $\mathrm{N}$ inputs, and the implication for plant-insect interactions.

There is ample evidence to suggest that insect herbivore behavior is strongly influenced by the nutritional quality of host species and that nutritional quality varies across species, at times independent of resource supply (Kleiner and Montgomery 1994; Traw et al. 1996; Kinney et al. 1997; Roth et al. 1997). The objectives of this study were to quantify foliar chemistry of tree seedlings exposed to reductions in water supply under elevated $\mathrm{N}$ conditions and assess larval performance of gypsy moth, Lymantria dispar L. (Lepidoptera: Lymantriidae), on two, intrageneric host species that differ in suitability to this generalist insect herbivore. I hypothesized that reductions in water supply to tree seedlings would reduce the expected 
improvement in foliar quality resulting from $\mathrm{N}$ addition to host plants. As a result, insect performance would be reduced, however consumption rates may be stimulated.

I predicted that these effects would be more apparent when larvae fed on gray birch, the more suitable host species. 


\section{METHODS}

\section{Study species}

Gray birch (Betula populifolia Marsh) and yellow birch (B. alleghaniensis Britton) occur in forests of eastern North America and differ in suitability as hosts for gypsy moth larvae (Burns and Honkala 1990; Liebhold et al. 1995). Gray birch is a pioneer species that requires high light and tolerates infertile soil conditions. Yellow birch appears in forests during later successional stages. It is moderately shade tolerant and requires greater soil fertility than gray birch (Burns and Honkala 1990). Both exhibit indeterminate growth and continuously produce new leaf tissue throughout the growing season.

Gypsy moths have been predominant defoliators of eastern North American forests since their introduction in 1869 . They are polyphagous folivores that perform differentially on a wide variety of tree species (Mauffette et al. 1983; Kinney et al. 1997). Larvae have been shown to prefer and perform better on gray birch compared to yellow birch and, therefore, gray birch is classified as a highly suitable host, while yellow birch is classified as a less suitable host for herbivory (Liebhold et al. 1995). For this study, late instar larvae (third to fourth stadium) were obtained from the USDA Animal and Plant Methods Center at Otis Air Force Base (Massachusetts, USA).

Gypsy moth exhibit a univoltine life cycle, with egg hatch occurring in early spring. Larvae feed through mid-summer and adults lay eggs in late summer to early fall. Adult females are flightless, yet larvae are mobile, highly sensitive to changes in foliar quality, and are largely responsible for host plant selection (Lance and Barbosa 1981; Lance and Barbosa 1982; Lance et al. 1991; Kinney et al. 1997). 


\section{Plant Growth}

Gray and yellow birch seedlings were grown for two years under $\mathrm{N}$ and water treatments at the

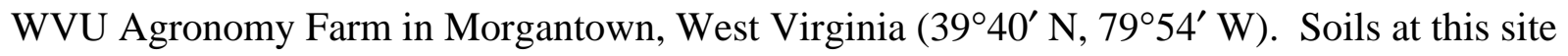
are classified as moderately well-drained Dormont and Guernsey silt loams with 8 to 15 percent slopes and are described as highly suitable for tree growth (Wright et al. 1982).

Seeds of gray and yellow birch, collected from Pennsylvania sources (F.W. Schumacher Co., Inc., Sandwich, MA), were stratified for three months at $4^{\circ} \mathrm{C}$, germinated in May 1997, and grown for four months under greenhouse conditions $\left(29^{\circ} \mathrm{C}\right.$ day, $18^{\circ} \mathrm{C}$ night $)$.

In early October 1997, gray and yellow birch seedlings were transplanted at the WVU Agronomy Farm into nine blocks of three, $3 \times 2 \mathrm{~m}$ subplots, each containing five trees per species (Fig 2.2). Within each subplot gray and yellow birch seedlings were planted together with red oak (Quercus rubra L.) and black locust seedlings (Robinia pseudoacacia L.), for a total of 20 seedlings planted in each subplot. Position of species within a subplot was randomly chosen and seedlings were planted $0.5 \mathrm{~m}$ apart. The interest in intrageneric differences between gray and yellow birch as host species for gypsy moth larvae limited the use of only these species in this study. Nitrogen treatments included ambient and two levels of $\mathrm{N}$ fertilization. Fertilized blocks received a single application of dry $\mathrm{NH}_{4} \mathrm{NO}_{3}$ at levels of $100 \mathrm{~kg} / \mathrm{ha} / \mathrm{yr}(\mathrm{n}=3)$ and 200 $\mathrm{kg} / \mathrm{yr} / \mathrm{ha}(\mathrm{n}=3)$ at the beginning of March 1998 and March 1999. $\mathrm{NH}_{4} \mathrm{NO}_{3}$ was broadcast over the soil around the base of the seedlings (radius $=0.5 \mathrm{~m}$ ). $\mathrm{N}$ levels for supplemented plots approximate a high level of $\mathrm{N}$ deposition into some fertilized Appalachian forests ( $35 \mathrm{~kg} \mathrm{~N} / \mathrm{ha}$; Gilliam et al. 1996) and a doubled level (70 kg N/ha), given the future of increased N inputs to these systems (Galloway 1995). Three control blocks received no fertilizer addition. 
Water availability to seedlings relied on natural rainfall events and was either reduced, ambient, or augmented. Water availability was reduced in nine, upslope subplots by capturing rainwater in open drainage pipes that covered approximately $25 \%$ of the subplot area. This water was diverted to nine, downslope, augmented subplots. A third set of nine supblots, flanked by the low and high-water subplots, served as an ambient condition. The ambient subplots had closed drainage pipes running through them, which did not alter the input of water from rainfall. Surface and subsurface water and nutrient flow was eliminated down to $3 \mathrm{~m}$ by plastic-lined trenches that separated the nine $\mathrm{N}$ treatment blocks from one another and the surrounding area. Soil water content was measured approximately weekly and precipitation and temperature were recorded daily throughout the growing seasons in 1998 and 1999. Differences among water treatments were maintained during the growing seasons by either the drainage pipe installation, the slightly-graded slope that the seedlings were planted on, or a combination of the two. Soil water content in reduced plots was lower than soil water content in augmented plots, throughout the two year period. The differences in soil water content between these water treatments ranged from below 5\% to about 10\%. Furthermore, during the 1999 growing season a drought occurred, as indicated by the overall lower precipitation and soil moisture values for that year.

\section{Leaf characteristics}

Leaf samples (4-5 leaves) were collected during the second week of August from each seedling subsequently used in the feeding trials to determine the effects of nitrogen and water availability on foliar chemistry. All samples were stored on ice and transported to the laboratory, where fresh mass and leaf area were measured (LI-3100 Area Meter, LiCor, Inc., Lincoln, NE, USA). Samples were dried at $65^{\circ} \mathrm{C}$ for 48 hrs before dry mass was measured. Leaf water content 
(LWC) was determined as the proportional difference between leaf fresh and dry weight. Specific leaf area (SLA) was calculated as the proportion of leaf area to dry mass of leaf tissue. Subsamples of this tissue were used to determine $\mathrm{C}$ and $\mathrm{N}$ concentration ratios, total nonstructural carbohydrates, total phenols, and condensed tannins on a dry weight basis. Subsamples (5 mg) were combusted in an elemental analyzer (NA1500, Carlo Erba Instrumentazoine, Milan, Italy) to determine leaf C and N concentrations. Subsamples (15 mg) were also assayed for total nonstructural carbohydrates using an acid hydrolysis method to separate sugars and starch from leaf tissue with a methanol:chloroform:water solution following Tissue and Wright (1995). For total phenol and condensed tannin analyses, leaf tissue (200 mg) was extracted on a shaker table overnight at room temperature in $50 \%$ methanol $(20 \mathrm{ml})$. Total phenols were determined by a modified prussian blue assay (Graham 1992), using $1.0 \mathrm{mM}$ gallic acid to construct a standard curve. Condensed tannins were quantified by the acid butanol method of Porter et al. (1986), using crude quebracho tannin as a reference standard. Chlorophyll concentration was determined using a portable chlorophyll meter (SPAD-502, Minolta, Osaka, Japan) and interpolated using a regression equation constructed from samples with known SPAD values and chlorophyll concentrations, obtained using the N,N dimethylformamide extraction method of Porra et al. (1989). Absorbance values for all colorimetric methods described above were obtained using a UV Spectrophotometer (UV-1601, Shimadzu, Tokyo, Japan).

\section{Feeding Trials}

Feeding trials were conducted in growth chambers (Econoair Ecological Chambers, Winnipeg, MB, Canada) during the second and third week of August 1999. Growth chambers were set to 
approximate early summer field conditions (14:10 L:D cycle at $23^{\circ}+/-0.5^{\circ} \mathrm{C}$, and $\left.70 \% \mathrm{RH}\right)$, and I measured foliar consumption, insect growth, and various larval nutritional indices. Two branches were harvested from each of six, field-grown seedlings within each Species x Nitrogen $\mathrm{x}$ Water treatment combination $(\mathrm{N}=108)$. Pairs of clipped branches $(\approx 30 \mathrm{~cm})$ were removed from the top-third portion of each seedling, proximally close to one another, and contained enough leaf tissue to provide larvae with continuous access to fresh foliage for approximately three days (Scriber 1977). Immediately after clipping and throughout the experiment, individual branches were kept hydrated using plastic vials filled with water and stoppered with rubber caps (Hough and Pimentel 1978; Roth and Lindroth 1994; Strom and Hain 1996). Fresh foliage was provided to larvae using the same method, every third day, over the two week experimental period.

Excised branches were individually weighed and one gypsy moth larva was weighed and placed inside a net bag surrounding each branch. Every third day, when foliage was replaced, larvae were re-weighed, frass was collected, and larvae were rotated between growth chambers to prevent differential effects due to chambers. Frass and branches that were replaced were dried at $65^{\circ} \mathrm{C}$ for $48 \mathrm{hrs}$ and weighed. Larval consumption rates were obtained by comparing final dry weights of these branches to their initial dry weights using fresh-dry weight conversions from a representative sample of branches within each treatment group $(n=6)$ not exposed to larvae. At the end of the two week period, larvae were dried at $65^{\circ} \mathrm{C}$ for $48 \mathrm{hrs}$ and weighed. Sample larvae $(n=20)$ were weighed both fresh and dry to express all fresh weights as dry weights for larval and nutritional calculations. Consumption rates and larval growth rates were expressed as mg food consumed/day and mg larval biomass gained/day. Nutritional indices were calculated according to the methods of Waldbauer (1968): approximate digestibility $(\mathrm{AD})=(\mathrm{mg}$ food 
ingested - mg frass / mg food ingested) X 100 (\%); efficiency of converting digested food to larval biomass $(\mathrm{ECD})=(\mathrm{mg}$ larval biomass gained $/ \mathrm{mg}$ food ingested $-\mathrm{mg}$ frass $) \times 100(\%) ;$ efficiency of converting ingested food to larval biomass $(\mathrm{ECI})=(\mathrm{mg}$ larval biomass gained $/ \mathrm{mg}$ food ingested) x $100(\%)$. The first four days of feeding trials were excluded from the calculation of nutritional indices to minimize error associated with food that larvae consumed prior to the feeding trials.

\section{Statistical Analysis}

All measurements of foliar chemistry and larval performance were analyzed using three-way ANOVAs to test for the effects of $\mathrm{N}$ availability, water availability, species, and their interactions (JMP, SAS Institute, Inc., Cary, NC). Seedlings damaged during previous, naturally-occurring defoliation events at the field site were excluded from the pool of randomlyselected seedlings for feeding trials, because these defoliation events could have altered leaf chemistry and resulting larval performance (Haukioja et al. 1985). This reduced replication and prevented the analysis of plot effects within the model. For all measures of larval performance, replicate pairs of clipped branches from the same plant were treated as a nested effect, with plant nested within the three-way interaction ( $\mathrm{x}$ Water $\mathrm{x}$ Species). Since larval growth rate, consumption rate, and their components were strongly correlated with larval weight at the onset of the experiment, we added initial larval dry weights to the model as a covariate. ECI and ECD data were ln-transformed to normally distribute data. All effects where $p<0.05$ were considered statistically significant. 


\section{RESULTS}

\section{Leaf characteristics}

Overall, gray and yellow birch seedlings differed across most leaf characters (Table 4.1). Gray birch leaves were thicker than yellow birch leaves (7\%) and contained greater water content (4\%; Table 4.2). $\mathrm{C} / \mathrm{N}$ ratios were $14 \%$ lower in gray birch leaves than yellow birch due, in part, to lower leaf sugar content (18\%). However, there were no differences in starch content between the two species. Analyses of carbon-based secondary compounds showed no differences between species in total phenols, but gray birch contained lower condensed tannin concentrations (41\%). Gray birch leaves had greater sugar/condensed tannin ratios (SUG/CT) than yellow birch $(62 \%)$ and greater $\mathrm{N}$ per leaf area $(10 \%)$.

There was a significant effect of N supply on SLA, where leaves of seedlings exposed to $200 \mathrm{~kg} / \mathrm{ha} / \mathrm{yr} \mathrm{NH}_{4} \mathrm{NO}_{3}$ were $10 \%$ thinner than leaves of seedlings exposed to $100 \mathrm{~kg} / \mathrm{ha} / \mathrm{yr}$ $\mathrm{NH}_{4} \mathrm{NO}_{3}$ (Table 4.2). Chlorophyll concentration was also sensitive to $\mathrm{N}$ availability, but the response was nonlinear. Seedlings exposed to $100 \mathrm{~kg} / \mathrm{ha} / \mathrm{yr} \mathrm{NH}_{4} \mathrm{NO}_{3}$ had the greatest foliar chlorophyll concentration. Addition of $200 \mathrm{~kg} / \mathrm{ha} / \mathrm{yr} \mathrm{NH}_{4} \mathrm{NO}_{3}$ did not continue to increase chlorophyll concentrations, nor did chlorophyll concentrations from seedlings in this treatment differ from those grown under no $\mathrm{N}$ supplementation (Table 4.2).

The effects of $\mathrm{N}$ on leaf $\mathrm{N}$ concentration differed between species (Table 4.1). Gray birch seedlings exposed to $100 \mathrm{~kg} / \mathrm{ha} / \mathrm{yr} \mathrm{NH}_{4} \mathrm{NO}_{3}$ had greater leaf $\mathrm{N}$ concentration than seedlings from no N addition treatments (14\%; Table 4.2). Similar to chlorophyll concentration, the response of leaf $\mathrm{N}$ to seedling $\mathrm{N}$ supply was not linear for gray birch. Leaf $\mathrm{N}$ concentration of seedlings exposed to $200 \mathrm{~kg} / \mathrm{ha} / \mathrm{yr} \mathrm{NH}_{4} \mathrm{NO}_{3}$ did not differ from those not exposed to 
Table 4.1. ANOVA results for effects of nitrogen, water availability and tree species on several foliar characteristics, including specific leaf area (SLA), leaf water content (LWC), carbon to nitrogen ratio (C/N), sugar (SUG), starch (STA), total phenol (TP), condensed tannin (CT), sugar to condensed tannin ratio (SUG/CT), nitrogen concentration $\left(\mathrm{N}_{\mathrm{A}}\right)$, and chlorophyll concentration $(\mathrm{CHL})$. Asterisks refer to the probability of a greater $F$ statistic calculated for the full factorial design: * $=0.01<P \leq 0.05$; ** $=0.001<P \leq$ 0.01; *** $P \leq 0.001$. Error degrees of freedom are 90 for SLA and LWC; 88 for $\mathrm{C} / \mathrm{N}$ and $\mathrm{N}_{\mathrm{A}} ; 87$ for TP and CT; 37 for SUG, STA, and SUG/CT; 142 for CHL.

\begin{tabular}{|c|c|c|c|c|c|c|c|c|c|c|c|}
\hline \multirow[t]{2}{*}{ Source } & \multirow[t]{2}{*}{$d f$} & \multicolumn{10}{|l|}{$F$-statistics } \\
\hline & & $\begin{array}{l}\text { SLA } \\
\left(\mathrm{cm}^{2} \mathrm{mg}^{-1}\right)\end{array}$ & $\begin{array}{l}\text { LWC } \\
(\%)\end{array}$ & $\begin{array}{l}\mathrm{C} / \mathrm{N} \\
\left(\mathrm{mg} \mathrm{mg}^{-1}\right)\end{array}$ & $\begin{array}{l}\text { SUG } \\
(\%)\end{array}$ & $\begin{array}{l}\text { STA } \\
(\%)\end{array}$ & $\begin{array}{l}\mathrm{TP} \\
\left(\mathrm{mg} \mathrm{L}^{-1}\right)\end{array}$ & $\begin{array}{l}\mathrm{CT} \\
\left(\mathrm{mg} \mathrm{ml}^{-1}\right)\end{array}$ & $\begin{array}{l}\text { SUG/CT } \\
\left(\mathrm{mg} \mathrm{mg}^{-1}\right)\end{array}$ & $\begin{array}{l}\mathrm{N}_{\mathrm{A}} \\
\left.(\mathrm{mg} \mathrm{cm})^{-2}\right)\end{array}$ & $\begin{array}{l}\mathrm{CHL} \\
\left(\mathrm{mg} \mathrm{cm}^{-2}\right)\end{array}$ \\
\hline $\mathrm{N}$ & 2 & $3.30 *$ & 1.73 & 0.22 & 0.13 & 0.59 & 0.53 & 0.53 & 0.79 & 1.90 & $8.91 * * *$ \\
\hline $\mathrm{H}_{2} \mathrm{O}$ & 2 & 2.17 & 1.10 & 0.34 & 1.54 & 0.49 & 1.28 & 0.94 & $5.49 * *$ & 0.53 & 0.87 \\
\hline $\mathrm{Sp}$ & 1 & $5.72 *$ & $28.60 * * *$ & $26.54 * * *$ & $9.53 * *$ & 0.05 & 0.01 & $68.36 * * *$ & $32.15 * * *$ & $12.21 * * *$ & 0.54 \\
\hline $\mathrm{N} \times \mathrm{H}_{2} \mathrm{O}$ & 4 & 1.18 & 0.34 & 0.75 & 0.18 & 0.57 & 0.67 & 0.18 & 0.18 & 1.01 & 1.40 \\
\hline $\mathrm{N} \times \mathrm{Sp}$ & 2 & 2.03 & 1.00 & 2.18 & 0.69 & 0.20 & 1.66 & 0.77 & 0.49 & $3.60 *$ & 2.78 \\
\hline $\mathrm{H}_{2} \mathrm{O} \times \mathrm{Sp}$ & 2 & 1.19 & 0.88 & 0.32 & 0.10 & 0.45 & 0.04 & 0.05 & 1.98 & 0.05 & 1.01 \\
\hline $\mathrm{N} \times \mathrm{H}_{2} \mathrm{O} \times \mathrm{Sp}$ & 4 & 1.64 & 1.39 & 1.07 & 0.91 & 0.30 & 1.59 & 1.69 & 0.99 & 1.59 & 1.95 \\
\hline Error & \multicolumn{11}{|c|}{$90,88,87,37,142$} \\
\hline
\end{tabular}


Table 4.2. Leaf characters of gray and yellow birch seedlings grown under varying levels of $\mathrm{N}$ and water availability. Values are means ( \pm SE). Leaf characters are specific leaf area (SLA), leaf water content (LWC), C/N ratio (C/N), sugar concentration (SUG), starch concentration (STA), total phenol concentration (TP), condensed tannin concentration (CT), sugar/condensed tannin ratio (SUG/CT), nitrogen concentration ( $\left.\mathrm{N}_{\mathrm{A}}\right)$, and chlorophyll concentration (CHL). $\mathrm{N}$ treatments are no $\mathrm{N}$ addition (No), $100 \mathrm{~kg} / \mathrm{ha} / \mathrm{yr} \mathrm{NH} \mathrm{NO}_{3}(100)$, and $200 \mathrm{~kg} / \mathrm{ha} / \mathrm{yr} \mathrm{NH} \mathrm{NO}_{3}(200)$. Water treatments are reduced (Red), ambient (Amb), and augmented (Aug).

\begin{tabular}{|c|c|c|c|c|c|c|c|c|c|c|}
\hline Character & Species & No/Red & $\mathrm{No} / \mathrm{Amb}$ & No/Aug & 100/Red & 100/Amb & 100/Aug & 200/Red & 200/Amb & 200/Aug \\
\hline SLA & gray birch & $0.17 \pm 0.01$ & $0.17 \pm 0.01$ & $0.17 \pm 0.01$ & $0.17 \pm 0.01$ & $0.16 \pm 0.01$ & $0.16 \pm 0.01$ & $0.17 \pm 0.01$ & $0.17 \pm 0.01$ & $0.17 \pm 0.01$ \\
\hline$\left(\mathrm{cm}^{2} \mathrm{mg}^{-1}\right)$ & yellow birch & $0.18 \pm 0.01$ & $0.17 \pm 0.01$ & $0.17 \pm 0.02$ & $0.14 \pm 0.01$ & $0.17 \pm 0.01$ & $0.18 \pm 0.02$ & $0.18 \pm 0.01$ & $0.23 \pm 0.03$ & $0.19 \pm 0.01$ \\
\hline LWC & gray birch & $58.5 \pm 0.4$ & $60.8 \pm 0.8$ & $60.0 \pm 0.7$ & $57.2 \pm 0.4$ & $60.0 \pm 1.1$ & $58.9 \pm 0.6$ & $59.4 \pm 1.1$ & $58.7 \pm 0.9$ & $59.6 \pm 1.0$ \\
\hline$(\%)$ & yellow birch & $56.0 \pm 1.2$ & $56.5 \pm 0.8$ & $57.2 \pm 0.9$ & $57.1 \pm 1.0$ & $56.1 \pm 1.2$ & $55.7 \pm 0.8$ & $57.3 \pm 1.6$ & $58.4 \pm 1.0$ & $57.1 \pm 0.7$ \\
\hline $\mathrm{C} / \mathrm{N}$ & gray birch & $21.6 \pm 1.3$ & $22.3 \pm 1.3$ & $22.0 \pm 1.0$ & $20.6 \pm 1.3$ & $19.3 \pm 0.8$ & $20.6 \pm 0.9$ & $22.0 \pm 0.9$ & $21.0 \pm 0.8$ & $21.4 \pm 1.8$ \\
\hline$\left(\mathrm{mg} \mathrm{mg} \mathrm{m}^{-1}\right)$ & yellow birch & $22.2 \pm 1.2$ & $22.8 \pm 0.8$ & $25.8 \pm 2.1$ & $25.2 \pm 1.6$ & $26.5 \pm 2.0$ & $23.6 \pm 1.9$ & $24.7 \pm 1.2$ & $23.7 \pm 0.9$ & $26.1 \pm 1.7$ \\
\hline SUG & gray birch & $11.2 \pm 1.9$ & $9.8 \pm 0.6$ & $10.1 \pm 2.0$ & $9.7 \pm 1.5$ & $9.0 \pm 0.2$ & $9.8 \pm 1.2$ & $12.2 \pm 0.5$ & $8.5 \pm 0.7$ & $10.0 \pm 1.9$ \\
\hline$(\%)$ & yellow birch & $12.2 \pm 0.5$ & $12.3 \pm 1.8$ & $12.6 \pm 2.1$ & $15.2 \pm 1.5$ & $11.4 \pm 1.9$ & $12.1 \pm 1.8$ & $11.0 \pm 1.4$ & $11.3 \pm 2.0$ & $12.3 \pm 1.7$ \\
\hline STA & gray birch & $10.6 \pm 0.4$ & $14.7 \pm 4.6$ & $12.4 \pm 1.3$ & $15.0 \pm 2.1$ & $12.9 \pm 1.9$ & $11.4 \pm 1.5$ & $14.0 \pm 1.0$ & $16.5 \pm 6.5$ & $11.8 \pm 2.5$ \\
\hline$(\%)$ & yellow birch & $11.6 \pm 1.2$ & $16.5 \pm 5.9$ & $12.9 \pm 0.1$ & $13.0 \pm 0.9$ & $11.5 \pm 1.6$ & $12.3 \pm 2.2$ & $13.4 \pm 1.0$ & $14.1 \pm 1.8$ & $17.0 \pm 5.7$ \\
\hline $\mathrm{TP}$ & gray birch & $3.5 \pm 0.21$ & $3.3 \pm 0.2$ & $3.6 \pm 0.3$ & $3.4 \pm 0.3$ & $2.8 \pm 0.2$ & $3.7 \pm 0.2$ & $3.5 \pm 0.2$ & $3.6 \pm 0.4$ & $3.2 \pm 0.3$ \\
\hline$\left(\mathrm{mg} \mathrm{L}^{-1}\right)$ & yellow birch & $3.9 \pm 0.2$ & $3.0 \pm 0.2$ & $3.8 \pm 0.6$ & $4.2 \pm 0.5$ & $3.6 \pm 0.8$ & $3.4 \pm 0.6$ & $3.3 \pm 0.3$ & $2.8 \pm 0.2$ & $3.4 \pm 0.5$ \\
\hline $\mathrm{CT}$ & gray birch & $0.25 \pm 0.04$ & $0.21 \pm 0.03$ & $0.24 \pm 0.05$ & $0.20 \pm 0.04$ & $0.17 \pm 0.02$ & $0.27 \pm 0.04$ & $0.22 \pm 0.04$ & $0.24 \pm 0.04$ & $0.21 \pm 0.03$ \\
\hline$\left(\mathrm{mg} \mathrm{ml}^{-1}\right)$ & yellow birch & $0.35 \pm 0.05$ & $0.37 \pm 0.03$ & $0.45 \pm 0.05$ & $0.40 \pm 0.05$ & $0.42 \pm 0.04$ & $0.38 \pm 0.05$ & $0.37 \pm 0.04$ & $0.31 \pm 0.03$ & $0.38 \pm 0.04$ \\
\hline SUG/CT & gray birch & $5.9 \pm 1.5$ & $4.7 \pm 0.8$ & $4.0 \pm 0.4$ & $6.5 \pm 0.5$ & $5.4 \pm 0.6$ & $4.5 \pm 1.9$ & $7.7 \pm 0.9$ & $4.6 \pm 0.6$ & $5.0 \pm 0.7$ \\
\hline$\left(m g \mathrm{mg}^{-1}\right)$ & yellow birch & $4.0 \pm 0.6$ & $3.2 \pm 0.6$ & $2.9 \pm 0.3$ & $3.3 \pm 0.3$ & $2.4 \pm 0.5$ & $3.4 \pm 0.3$ & $3.8 \pm 0.7$ & $4.1 \pm 0.4$ & $3.0 \pm 0.2$ \\
\hline $\mathrm{N}_{\mathrm{A}}$ & gray birch & $9.6 \pm 0.6$ & $9.0 \pm 0.7$ & $9.4 \pm 0.5$ & $11.0 \pm 0.7$ & $10.6 \pm 0.4$ & $10.2 \pm 0.4$ & $9.3 \pm 0.5$ & $10.2 \pm 0.3$ & $9.7 \pm 1.0$ \\
\hline$\left(\mathrm{mg} \mathrm{cm}^{-2}\right)$ & yellow birch & $10.1 \pm 0.5$ & $9.6 \pm 0.4$ & $8.4 \pm 0.5$ & $8.6 \pm 0.5$ & $8.6 \pm 0.7$ & $9.7 \pm 0.6$ & $8.8 \pm 0.3$ & $8.9 \pm 0.5$ & $8.2 \pm 0.6$ \\
\hline CHL & gray birch & $1.13 \pm 0.01$ & $1.08 \pm 0.03$ & $1.04 \pm 0.05$ & $1.09 \pm 0.02$ & $1.09 \pm 0.02$ & $1.09 \pm 0.02$ & $1.05 \pm 0.03$ & $1.02 \pm 0.03$ & $1.06 \pm 0.02$ \\
\hline$\left(\mathrm{mg} \mathrm{cm}^{-2}\right)$ & yellow birch & $1.04 \pm 0.02$ & $1.05 \pm 0.05$ & $1.04 \pm 0.04$ & $1.11 \pm 0.02$ & $1.12 \pm 0.02$ & $1.07 \pm 0.01$ & $1.04 \pm 0.01$ & $0.98 \pm 0.01$ & $0.98 \pm 0.01$ \\
\hline
\end{tabular}


supplemental $\mathrm{N}$. Leaf $\mathrm{N}$ of yellow birch did not differ as a function of seedling $\mathrm{N}$ availability (Table 4.2). There was a trend toward $\mathrm{N}$ supply having a species-dependent effect on chlorophyll concentration ( $\mathrm{p}=0.07$ ). Leaves of yellow birch seedlings exposed to $100 \mathrm{~kg} / \mathrm{ha} / \mathrm{yr}$ $\mathrm{NH}_{4} \mathrm{NO}_{3}$ had slightly greater chlorophyll concentrations than leaves of seedlings exposed to both $200 \mathrm{~kg} / \mathrm{ha} / \mathrm{yr} \mathrm{NH}_{4} \mathrm{NO}_{3}(11 \%)$ and no $\mathrm{N}$ addition (6\%). In gray birch, there were no differences in chlorophyll concentration as a function of $\mathrm{N}$ supply to seedlings (Table 4.2).

SUG/CT was the only leaf character altered by seedling water availability (Table 4.1). I found that the reduction in water availability from augmented to reduced conditions increased SUG/CT 38\% (Table 4.2).

\section{Feeding Trials}

I observed significant effects of species, water, and their interactions with nitrogen on several parameters of insect performance (Table 4.3). Across $\mathrm{N}$ and water treatments, larvae fed gray birch leaves had higher growth rates than those fed yellow birch leaves (70\%), yet larvae did not consume leaves of gray and yellow birch at different rates (Fig. 4.1). Overall, gypsy moth larvae did not differ in their efficiency of converting digested gray or yellow birch tissue into biomass, but they were more efficient at converting ingested gray birch tissue into biomass, compared to yellow birch tissue (Fig. 4.2).

Growth rate was significantly affected by $\mathrm{N}$ treatment (Table 4.3). Larvae fed leaves from $200 \mathrm{~kg} / \mathrm{ha} / \mathrm{yr} \mathrm{NH}_{4} \mathrm{NO}_{3}$ had lower growth rates (18\%) compared to those fed leaves grown under $100 \mathrm{~kg} / \mathrm{ha} / \mathrm{yr} \mathrm{NH} \mathrm{NO}_{3}$ (Fig. 4.1).

There was a significant effect of seedling water supply on larval growth rate and consumption rate (Table 4.3). Larval growth rate increased $16 \%$ and larval consumption rate 
Table 4.3. ANOVA results for effects of nitrogen, water availability, and tree species on larval growth rate, consumption rate, approximate digestibility (AD), efficiency of converting digested food into larval biomass (ECD), and efficiency of converting ingested food into larval biomass (ECI). Values for ECI and ECD were ln transformed to normalize the distribution of data. Asterisks refer to the probability of a greater $F$ statistic calculated for the full factorial design: * $=$ $0.01<P \leq 0.05 ; * *=0.001<P \leq 0.01 ; * * * P \leq 0.001$. Error degrees of freedom are 193 for growth rate, 103 for consumption rate, 134 for $\mathrm{AD}, 112$ for ECD, and 155 for ECI. For the Plant $\left(\mathrm{N}_{x ~ \mathrm{H}_{2}} \mathrm{O} \times \mathrm{Sp}\right)$ effect, n.s. indicates that the nested effect was not significant $(\mathrm{p}<0.05)$ and it was excluded from the model during analysis of those parameters.

\begin{tabular}{lrlllll}
\hline Source & $d f$ & $F$-statistics & & \\
\cline { 2 - 6 } & & $\begin{array}{l}\text { Growth rate } \\
\left(\mathrm{mg} \mathrm{d}^{-1}\right)\end{array}$ & $\begin{array}{l}\text { Consumption rate } \\
\left(\mathrm{mg} \mathrm{d}^{-1}\right)\end{array}$ & $\begin{array}{l}\text { AD } \\
(\%)\end{array}$ & $\begin{array}{l}\text { ECD } \\
(\%)\end{array}$ & $\begin{array}{l}\text { ECI } \\
(\%)\end{array}$ \\
\hline $\mathrm{N}$ & 2 & $3.21^{*}$ & 0.50 & 1.37 & 1.03 & 0.03 \\
$\mathrm{H}_{2} \mathrm{O}$ & 2 & $3.19^{*}$ & $4.01^{*}$ & 0.18 & $3.02^{*}$ & 2.45 \\
$\mathrm{Sp}$ & 1 & $56.03^{* * *}$ & 0.24 & 3.09 & 0.30 & $9.74^{* *}$ \\
$\mathrm{~N} \times \mathrm{H}_{2} \mathrm{O}$ & 4 & 0.74 & 1.76 & $4.14^{* *}$ & 1.75 & 0.15 \\
$\mathrm{~N} \times \mathrm{Sp}$ & 2 & 0.97 & $4.87^{* *}$ & $5.41^{* *}$ & 0.97 & $5.70^{* *}$ \\
$\mathrm{H}_{2} \mathrm{O} \times \mathrm{Sp}$ & 2 & 0.60 & 0.07 & 0.69 & 1.88 & 1.01 \\
$\mathrm{~N} \times \mathrm{H}_{2} \mathrm{O} \times \mathrm{Sp}$ & 4 & 0.29 & 1.13 & $5.06^{* * *}$ & 1.14 & 2.91 \\
$\mathrm{Plant}\left(\mathrm{N} \times \mathrm{H}_{2} \mathrm{O} \times \mathrm{Sp}\right)$ & 90 & n.s. & $1.61^{*}$ & n.s. & $2.19^{* *}$ & $1.88^{*}$ \\
Error $193,103,134,112,155$ & & & & \\
\hline
\end{tabular}


Fig. 4.1. Growth rate and consumption rate of gypsy moth larvae fed gray and yellow birch foliage grown under varying $\mathrm{N}$ and water availability. . Standard error bars show $1 \mathrm{SE} \pm$ treatment means. Open bars are reduced water treatment, hatched bars are ambient water treatment, and closed bars are augmented water treatment $(n=6)$. 

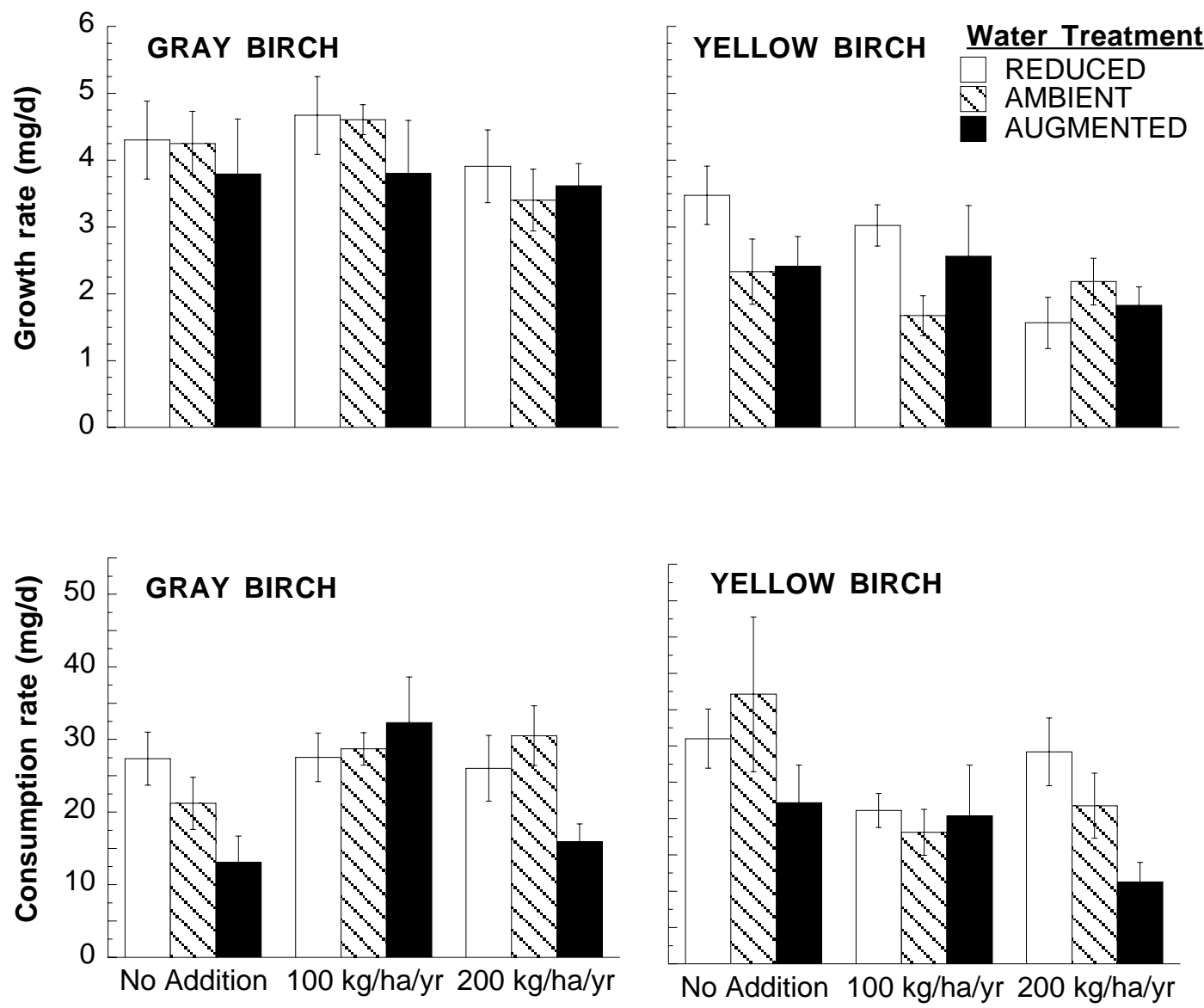

\section{Nitrogen Treatment}

Fig. 4.1 
Fig. 4.2. Approximate digestibility (AD), efficiency of converting digested food (ECD), and efficiency of converting ingested food (ECI) into larval biomass for gypsy moth larvae fed gray and yellow birch foliage grown under varying $\mathrm{N}$ and water availability. Standard error bars show $1 \mathrm{SE} \pm$ treatment means. Open bars are reduced water treatment, hatched bars are ambient water treatment, and closed bars are augmented water treatment $(n=6)$. 

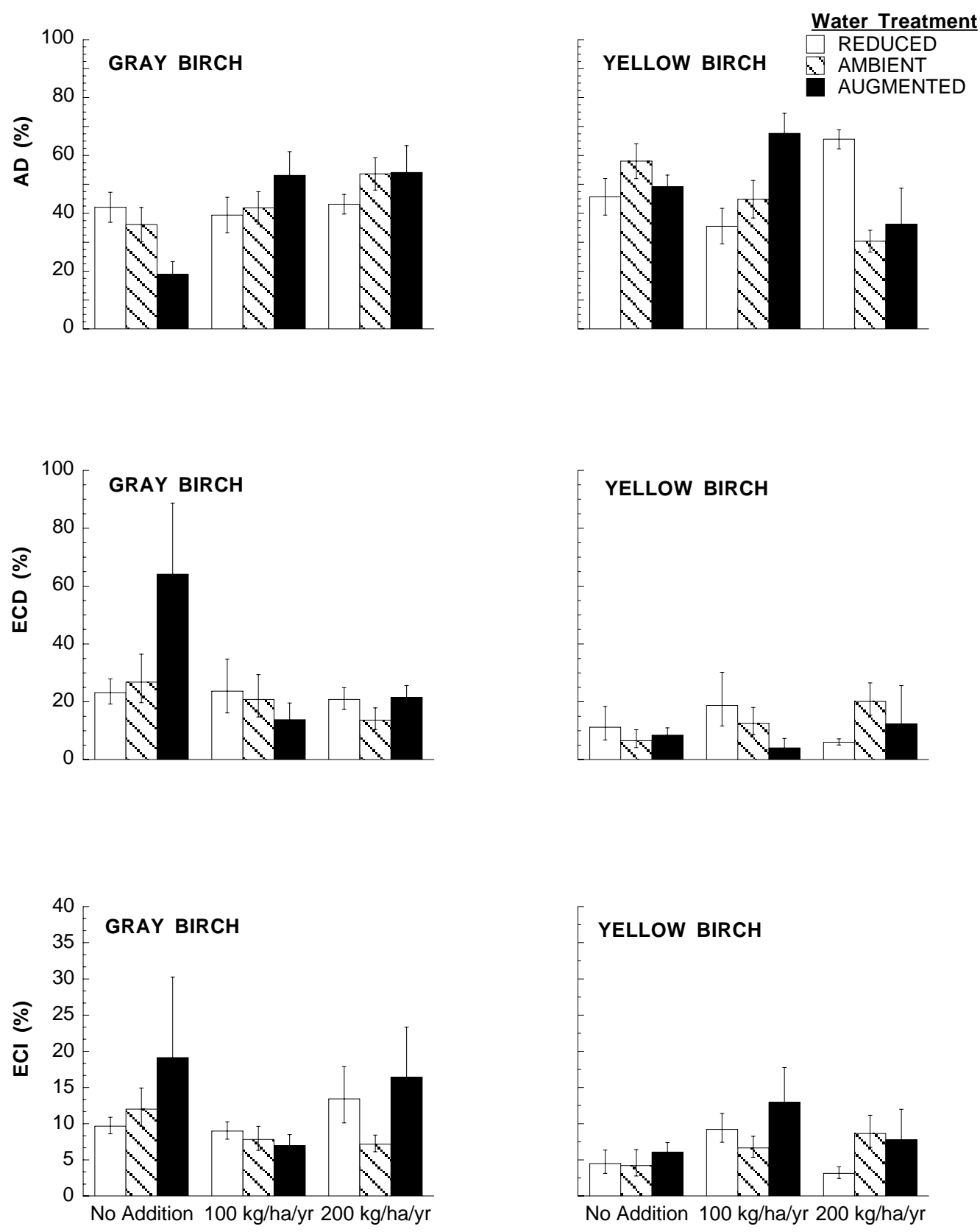

Nitrogen Treatment

Fig. 4.2 
increased $39 \%$ as water availability decreased from augmented to reduced conditions (Fig. 4.1). There was also a significant effect of water availability on ECD (Table 4.3). As water availability was reduced from augmented to reduced conditions, ECD was stimulated $9 \%$.

Larvae consumed foliage from species differently as a function of $\mathrm{N}$ availability (Table 4.3). Larvae fed gray birch showed no changes in consumption as a function of seedling $\mathrm{N}$ supply, whereas those fed yellow birch consumed foliage from no $\mathrm{N}$ addition treatments at a faster rate than foliage from $\mathrm{N}$-fertilized treatments (Fig. 4.1).

There were significant three-way interactive effects for the effects of species, $\mathrm{N}$, and water on $\mathrm{AD}$ and $\mathrm{ECI}$ (Table 4.3). When larvae were fed foliage from no $\mathrm{N}$ addition treatments, $\mathrm{AD}$ of gray birch leaves decreased with increasing water availability and did not change as a function of water availability for yellow birch leaves. When larvae were fed leaves grown under $100 \mathrm{~kg} / \mathrm{ha} / \mathrm{yr}, \mathrm{AD}$ increased with increasing water availability in both species. At the highest $\mathrm{N}$ availability, increasing water availability stimulated AD when larvae were fed gray birch leaves, but decreased $\mathrm{AD}$ when larvae were fed yellow birch leaves (Fig. 4.2). Larval efficiency at converting ingested food into biomass is the mathematical product of AD and ECD. Patterns of ECI were most similar to and appeared to be determined by ECD (Fig. 4.2). Under no N addition and $100 \mathrm{~kg} / \mathrm{ha} / \mathrm{yr} \mathrm{NH}_{4} \mathrm{NO}_{3}$ treatments, increasing water availability did not affect ECI. When larvae were fed leaves grown under the highest $\mathrm{N}$ condition, ECI of larvae fed gray birch leaves decreased under ambient water conditions and increased under ambient and augmented water conditions when larvae were fed yellow birch leaves. 


\section{DISCUSSION}

Emerging evidence indicates that insect herbivores may respond in an unpredictable fashion when fed leaves of plants grown under water stress and elevated $\mathrm{N}$ conditions (Thomas and Hodkinson 1991; Dudt and Shure 1994; English-Loeb et al. 1997; Suomela and Neuvonen 1997). My study, which focused on gypsy moth response to leaves of seedlings grown under variations in $\mathrm{N}$ and water supply, adds to this evidence. I predicted that, in support of the $\mathrm{CNB}$ hypothesis, $\mathrm{N}$ fertilization would increase leaf $\mathrm{N}$ and reduce concentrations of $\mathrm{C}$-based secondary compounds. I also hypothesized that reductions in water supply would decrease foliar quality to gypsy moth larvae, but increase their consumption rate of this lower quality foliage. I found weak evidence to support both hypotheses and strong evidence that gypsy moth performance is dependent on plant species, rather than resource-mediated changes in foliar chemistry.

I found strong species differences across most leaf characters. I found that gray birch was a more nutritiously suitable host species for gypsy moth, compared to yellow birch. Gray birch leaves were slightly thicker and contained higher LWC, sugar concentration, $\mathrm{N}$ concentration, and SUG/CT. Gray birch foliage also contained lower C/N ratios and lower condensed tannin concentrations than yellow birch. These results are consistent with those of other deciduous species, where fast-growing, shade-intolerant species, such as gray birch, contained lower levels of carbon-based secondary compounds than slower growing, shadetolerant species, like yellow birch (Coley et al 1985; Dudt and Shure 1994). Differences in foliar chemistry found in the present study between leaves of gray birch and yellow birch provide strong evidence that gray birch is a more suitable host species for gypsy moth larvae than yellow birch (Liebhold et al. 1995; Traw et al. 1996). 
Varying water availability to seedlings grown under elevated $\mathrm{N}$ minimally affected the foliar characters I measured. There is evidence that, in accordance CNB hypothesis, foliar $\mathrm{N}$ concentrations increase and carbon-based compounds decrease with $\mathrm{N}$ fertilization, resulting in higher quality foliage for insect herbivores (Bryant et al. 1983; Thomas and Hodkinson 1991; Erelli et al. 1998; Hättenschwiler and Schafellner 1999). While I observed increased foliar N and chlorophyll concentrations with $\mathrm{N}$ fertilization, these responses were nonlinear and species dependent. Response of foliar $\mathrm{N}$ compounds resembled a convex pattern, with the greatest increase observed in seedlings grown under $100 \mathrm{~kg} / \mathrm{ha} / \mathrm{yr} \mathrm{NH}_{4} \mathrm{NO}_{3}$. These results are similar to those that have shown an initial pulse in foliar $\mathrm{N}$ levels during early stages of $\mathrm{N}$ fertilization, followed by a return to pre-application levels with further $\mathrm{N}$ addition (Aber et al. 1989; Yarie and Van Cleve 1996). Also similar to my study, other studies have failed to find changes in carbohydrate concentrations of various deciduous tree species when exposed to manipulations that were predicted to alter foliar chemistry (Lindroth et al. 1993; Dudt and Shure 1994; Roth and Lindroth 1994).

I hypothesized that foliar quality of elevated $\mathrm{N}$ foliage would have been reduced further under reduced water conditions. However, with the exception of foliar SUG/CT, water availability did not affect foliar characters. There is evidence from previous studies that water stress increases the size of the SUG/CT ratio by stimulating sugar concentrations more than tannins, and that this ratio is positively related to host plant selection by gypsy moth (Mattson and Haack 1987). In support of these findings, I found that foliar SUG/CT ratios were stimulated by reduced water availability. Furthermore, I found that this ratio was higher in gray birch foliage and, across most parameters, gypsy moth larvae fed gray birch tissue outperformed larvae fed yellow birch tissue. 
Although I detected few N- and water-induced changes in foliar chemistry, patterns of larval performance implied that gypsy moth were sensitive to differences in leaves of host species when seedlings were grown under variations in water supply and elevated $\mathrm{N}$ levels. I found that larval response reflected the nonlinear patterns of elevated nitrogen availability on foliar $\mathrm{N}$ compounds. Growth rates of larvae fed foliage from seedlings exposed to $200 \mathrm{~kg} / \mathrm{ha} / \mathrm{yr}$ were lower than those fed foliage exposed to $100 \mathrm{~kg} / \mathrm{ha} / \mathrm{yr}$.

Larvae also showed evidence of compensatory feeding behavior (Slansky and Wheeler 1992). When fed a less nutritive species, yellow birch, larvae consumed tissue from no $\mathrm{N}$ treatments at a faster rate than tissue from $\mathrm{N}$-fertilized treatments. I also found that larvae consumed foliage from low water treatments at a faster rate and had a higher efficiency at converting digested low water foliage than foliage from high water treatments. Larvae also exhibited faster growth rates when fed low water foliage, compared to high water foliage, regardless of species or $\mathrm{N}$ supply. These changes in larval performance, however, were only minimally affected by changes in foliar chemistry, since the only nutritive character to be altered by water availability were foliar SUG/CT ratios. Results from this study agree with others, that the effects of reduced water availability on foliar chemistry and resulting insect performance are nonlinear and inconsistent (Thomas and Hodkinson 1991; Floater 1997).

I found strong differences due to treatment interactions on foliar digestibility and larval biomass conversion efficiencies. At the lower level of $\mathrm{N}$ addition $(100 \mathrm{~kg} / \mathrm{ha} / \mathrm{yr})$, reductions in water availability enhanced ECD of foliage to larvae, providing evidence in support of the plantstress hypothesis. However, contrary to the plant-stress hypothesis, AD of foliage was reduced under these conditions and consequently, ECI was unaffected. In support of the plant-stress hypothesis, reduced water availability enhanced $\mathrm{AD}$ of yellow birch foliage grown under the 
higher level of $\mathrm{N}$ addition ( $200 \mathrm{~kg} / \mathrm{ha} / \mathrm{yr})$. The same conditions reduced larval ECI, which provided evidence contrary to the plant-stress hypothesis. I found that the effects on biomass conversion efficiencies were greatest when larvae fed on gray birch tissue. My results do not support those of Thomas and Hodkinson (1991), who showed that the effects of drought-stressed foliage on insect performance were greatest on plants from low $\mathrm{N}$ environments. With the exception of AD of gray birch leaves, I also found no evidence for improved nutritional indices when water was reduced under no $\mathrm{N}$ supplementation.

In summary, results from this study reveal that some aspects of foliar chemistry are sensitive to reductions in water availability under elevated $\mathrm{N}$ conditions and that these manipulations are associated with changes in performance of gypsy moth larvae. My results indicate that larval nutritional indices will be more sensitive to and more unpredictable in waterstressed, elevated $\mathrm{N}$ environments. However, these changes in larval performance do not appear to greatly stimulate larval growth and consumption rates in ways that would exacerbate insect outbreaks and forest tree defoliation. More importantly, like Traw et al. (1997), I found that gypsy moth performance is highly dependent on host plant species. These strong speciesdependent effects suggest that the interactive effects of resource supply on seedling growth and factors influencing species composition will be more important than their effects on foliar quality in determining forest susceptibility to insect outbreaks of generalist insect herbivores. 


\section{REFERENCES}

Aber JD, Nadelhoffer KJ, Steudler P, Melillo JM (1989) Nitrogen saturation in northern forest ecosystems. Bioscience 39:378-386

Aber JD, McDowell W, Nadelhoffer K, Magill A, Berntson G, Kamakea M, McNulty S, Currie W, Rustad L, Fernandez I (1998) Nitrogen saturation in temperate forest ecosystems. BioScience 48:921-934

Bezemer TM, Jones TH (1998) Plant-insect herbivore interactions in elevated atmospheric $\mathrm{CO}_{2}$ : quantitative analyses and guild effects. Oikos 82:212-222

Bryant JP, Chapin FS III, Klein DR (1983) Carbon/nutrient balance of boreal plants in relation to vertebrate herbivory. Oikos 40:357-368

Burns RM, Honkala BH (1990) Silvics of North America, vol 2. Hardwoods. USDA, Washington

Chapin FS III, Bloom AJ, Field CB, Waring RH (1987) Plant responses to multiple environmental factors. BioScience 37:49-57

Coley PD, Bryant JP, Chapin FS III (1985) Resource availability and plant antiherbivore defense. Science 230:895-899

Coley PD (1998) Possible effects of climate change on plant/herbivore interactions in moist tropical forests. Climatic Change 39:455-472

Dudt JF, Shure DJ (1994) The influence of light and nutrients on foliar phenolics and insect herbivory. Ecology 75:86-98 
English-Loeb G, Stout MJ, Duffey SS (1997) Drought stress in tomatoes: changes in plant chemistry and potential nonlinear consequences for insect herbivores. Oikos 79:456-468

Erelli MC, Ayres MP, Eaton GK (1998) Altitudinal patterns in host suitability for forest insects. Oecologia 117:133-142

Estiarte M, Filella I, Serra J., Peñuelas J (1994) Effects of nutrient and water stress on leaf phenolic content of peppers and susceptibility to generalist herbivore Helicoverpa armigera (Hubner). Oecologia 99:387-391

Fenn ME, Poth MA, Aber JD, Baron JS, Bormann BT, Johnson DW, Lemly AD, McNulty SG, Ryan DF, Stottlemyer R (1998) Nitrogen excess in North American ecosystems: predisposing factors, ecosystem responses, and management strategies. Ecol Appl 8:706-733

Floater GJ (1997) Rainfall, nitrogen and host plant condition: consequences for the processionary caterpillar, Ochrogaster lunifer. Ecol Entomol 22:247-255

Gershenzon J (1984) Changes in levels of plant secondary metabolites under water and nutrient stress. In: Timmermann C, Steelink C, Loewus FA (eds) Phytochemical adaptations to stress. Plenum, New York, pp 273-320

Graham HD (1995) Modified prussian blue assay for total phenols. In: Hagerman AE Tannin analysis. Miami University, Oxford, pp 7-8

Hättenschwiler S, Schafellner C (1999) Opposing effects of elevated $\mathrm{CO}_{2}$ and $\mathrm{N}$ deposition on Lymantria monacha larvae feeding on spruce trees. Oecologia $118: 210-217$ 
Haukioja E, Niemelä P, S Sirén (1985) Foliage penols and nitrogen in relation to growth, insect damage, and ability to recover after defoliation, in the mountain birch Betula pubescens ssp tortuosa. Oecologia 65: 214-222

Herms DA, Mattson WJ (1992) The dilemma of plants: to grow or defend? Q Rev Biol 67:283-335

Höft M, Verpoorte R, Beck E (1996) Growth and alkaloid contents in leaves of Tabernaemontana pachysiphon Stapf (Apocynaceae) as influenced by light intensity, water, and nutrient supply. Oecologia 107:160-169

Hough JA, Pimentel D (1978) Influence of host foliage on development, survival, and fecundity of the gypsy moth. Environ Entomol 7:97-102

Kleiner KW, Montgomery ME (1994) Forest stand susceptibility to the gypsy moth (Lepidoptera: Lymantriidae): species and site effects on foliage quality to larvae. Environ Entomol 23:699-711

Kinney KK, Lindroth RL, Jung SM, Nordheim EV (1997) Effects of $\mathrm{CO}_{2}$ and $\mathrm{NO}_{3}^{-}$ availability on deciduous trees: phytochemistry and insect performance. Ecology $78: 215-230$

Lance D, Barbosa P (1981) Host tree influences on the dispersl of first instar gypsy moths, Lymantria dispar (L.). Ecol Entomol 6:411-416

Lance D, Barbosa P (1982) Host tree influences on the dispersal of late instar gypsy moths, Lymantria dispar. Oikos 38:1-7

Lance DR, Elkinton JS Schwalbe CP (1991) Responses of gypsy moth larvae (Lepidoptera: Lymantriidae) to foliage of oaks from naturally infested sites on Cape Cod, Massachusetts. J Entomol Sci 26:214-222 
Liebhold AM, Gottschalk KW, Muzika RM, Montgomery ME, Young R, O'Day K, Kelly B (1995) Suitability of North American tree species to the gypsy moth: a summary of field and laboratory tests. USDA Forest Service general technical report NC-211. NE Forest Experiment Station, Morgantown

Lindroth RL, Kinney KK, Platz CL (1993) Responses of deciduous trees to elevated atmospheric $\mathrm{CO}_{2}$ : productivity, phytochemistry, and insect performance. Ecology $74: 763-777$

Mattson WJ Jr (1980) Herbivory in relation to plant nitrogen content. Annu Rev Ecol Syst 11:119-161

Mattson WJ, Haack RA (1987) The role of drought in outbreaks of plant-eating insects. Bioscience 37:110-118

Mauffette Y, Lechowicz MJ, Jobin L (1983) Host preferences of the gypsy moth, Lymantria dispar (L.), in southern Quebec. Can J For Res 13:53-60

Porra RJ, Thompson WA, Kriedemann PE (1989) Determination of accurate extinction coefficients and simultaneous equations for assaying chlorophylls $\underline{a}$ and $\underline{b}$ extracted with four different solvents: verification of the concentration of chlorophyll standards by atomic absorption spectroscopy. Biochim Biophys Acta 975:384-394

Porter LJ, Hrstich LN, Chan BG (1986) The conversion of procyanidins and prodelphinidins to cyanidin and delphinidin. Phytochem 25:223-230

Rhoades DF (1979) Evolution of plant chemical defense against herbivores. In: Rosenthal GA, Janzen DH (ed) Herbivores: their interactions with secondary plant metabolites. Academic Press, New York, pp 3-54 
Roth SK, Lindroth RL (1994) Effects of $\mathrm{CO}_{2}$-mediated changes in paper birch and white pine chemistry on gypsy moth performance. Oecologia 98:133-138

Roth S, McDonald EP, Lindroth RL (1997) Atmospheric $\mathrm{CO}_{2}$ and soil water availability: consequences for tree-insect interactions. Can J For Res 27:1281-1290

Scriber JM (1977) Limiting effects of low-water content on the nitrogen utilization, energy budget, and larval growth of Hyalophora cecropia (Lepidoptera: Saturniidae). Oecologia 28:269-287

Shure DJ, Mooreside PD, Ogle SM (1998) Rainfall effects on plant-herbivore processes in an upland oak forest. Ecology 79:604-617

Slanksy F Jr, Wheeler GS (1992) Caterpillars' compensatory feeding response to diluted nutrients leads to toxic allelochemical dose. Entomol Exp Appl 65:171-186

Strom BL, Hain FP (1996) Host choice of late instar gypsy moths (Lepidoptera: Lymantriidae) between loblolly pine and sweetgum. Environ Entomol 25:603-610

Suomela J, Neuvonen S (1997) Effects of long-term simulated acid rain on suitability of mountain birch for Epirrita autumnata (Geometridae). Can J For Res 27:248-256

Thomas AT, Hodkinson ID (1991) Nitrogen, water stress and the feeding efficiency of lepidopteran herbivores. J Appl Ecol 28:703-720

Tissue DT, Wright SJ (1995) Effect of seasonal water availability on phenology and the annual shoot carbohydrate cycle of tropical forest shrubs. Funct Ecol 9:518-527

Traw MB, Lindroth RL, Bazzaz FA (1996) Decline in gypsy moth (Lymantria dispar) performance in an elevated $\mathrm{CO}_{2}$ atmosphere depends upon host plant species. Oecologia 108:113-120 
Waldbauer GP (1968) The consumption and utilization of food by insects. Adv Insect Physiol 5:229-288

Waterman PG, Mole S (1994) Analysis of phenolic plant metabolites. Blackwell Scientific Publications, London

Wetherald RT, Manabe S (1999) Detectability of summer dryness caused by greenhouse warming. Climatic Change 43:495-511

White TCR (1984) The abundance of invertebrate herbivores in relation to the availability of nitrogen in stressed food plants. Oecologia 63:90-105

Williams RS, Lincoln DE, Thomas RB (1997) Effects of elevated $\mathrm{CO}_{2}$-grown loblolly pine needles on the growth, consumption, development, and pupal weight of redheaded pine sawfly larvae reared within open-topped chambers. Global Change Biol 3:501-511

Wong SC (1979) Elevated atmospheric partial pressure of $\mathrm{CO}_{2}$ and plant growth. Oecologia 44:68-74

Yarie J, Van Cleve K (1996) Effects of carbon, fertilizer, and drought on foliar chemistry of tree species in interior Alaska. Ecol Appl 6:815-827 


\section{GENERAL DISCUSSION}

The purpose of this research was to test the hypothesis that elevated $\mathrm{N}$ exacerbates tree seedling response to water limitations and to examine the consequences that these responses have on herbivory by a generalist insect folivore. In the first experiment, I examined growth and biomass allocation of three deciduous tree species exposed to variations in water supply and elevated N. I expected that elevated $\mathrm{N}$ supply would stimulate growth and seedlings would allocate biomass in favor of shoot production, at the expense of root production. Several studies have shown a similar response for deciduous and coniferous species when grown under elevated $\mathrm{N}$ conditions (Osonubi and Davies 1981; Emmett et al. 1995; De Visser et al. 1996; Lippert et al. 1996). Many of these studies have also shown that plants exhibiting these responses are more susceptible to drought injury (Van der Eerden and Perez-Soba 1992; Ibrahim et al. 1998).

I found some evidence to support this hypothesis, but the effects varied among the species I examined. Gray and yellow birch both showed increases in total biomass, growth rates, and leaf area production with $\mathrm{N}$ addition. I did not, however, observe reductions in root growth for either birch species. On the other hand, total biomass, growth rates, and shoot growth of red oak seedlings were not responsive to $\mathrm{N}$ addition, but root weight ratios and, thus $\mathrm{R}: \mathrm{S}$ ratios were significantly reduced with $\mathrm{N}$ addition. Despite the fact that I did not observe any effects of reduced water availability on seedling growth, I concluded that seedling response to elevated $\mathrm{N}$ increases the potential for transpirational water loss in birch seedlings and decreases the potential for water uptake in red oak seedlings. I also observed that elevated $\mathrm{N}$ stimulated net assimilation rates of both birch species. In all cases where elevated $\mathrm{N}$ stimulated growth characters, response of yellow birch seedlings was more pronounced, relative to gray birch seedlings. These birch 
species occur in northeastern North American forests and both exhibit different life history traits (Burns and Honkala 1990). Given the sensitivity of yellow birch seedling growth and biomass allocation to elevated $\mathrm{N}$ availability, I suggested that elevated $\mathrm{N}$ deposition into North American forests could alter competitive interactions between gray birch, yellow birch, and red oak seedlings.

In the second experiment, I hypothesized that the increased potential to experience water stress, exhibited by the N-induced stimulation of shoot growth in both birch species, would manifest itself at the leaf level, mostly through changes in stomatal conductance and resourceuse efficiency. I examined instantaneous photosynthetic response, photosynthetic capacity, and leaf properties of gray and yellow birch seedlings exposed to variations in water supply under elevated $\mathrm{N}$ conditions. I expected to see increased photosynthetic rates in seedlings grown under elevated $\mathrm{N}$ treatments. As water supply to these seedlings decreased, I expected to see reduced stomatal conductance and improved water-use efficiency. I found little evidence to support my hypotheses. Gray birch seedlings showed a greater photosynthetic response than yellow birch seedlings, but neither was sensitive to $\mathrm{N}$ and water supply across most measures of photosynthetic response. Overall, I found that $\mathrm{A}_{\text {net }}, \mathrm{g}_{\mathrm{s}}$, photosynthetic capacity, $\mathrm{P}_{\mathrm{WUE}}, \mathrm{P}_{\mathrm{NUE}}$, foliar $\mathrm{N}$, and chlorophyll concentrations were greater for gray birch seedlings, than yellow birch seedlings. These results were expected, due to the faster growth rate of this early successional species.

Aside from differing in growth rates and resource requirements, gray and yellow birch differ in host suitability for gypsy moth larvae (Liebhold et al. 1995; Traw et al. 1996). I conducted the third experiment to determine how variations in water availability would alter foliar chemistry of seedlings grown under elevated $\mathrm{N}$ conditions and foliar quality to gypsy 
moth. I tested two hypotheses: (1) seedlings exposed to elevated N would produce high quality foliage for herbivores, with relatively greater concentrations of $\mathrm{N}$-containing compounds and lower concentrations of C-containing compounds (the carbon/nutrient balance hypothesis; Bryant et al. 1983) and (2) that the high foliar quality of leaves from elevated $\mathrm{N}$ treatments would decrease for plants exposed to reduced water availability. I found that foliar $\mathrm{N}$ and chlorophyll concentrations were stimulated with $\mathrm{N}\left(100 \mathrm{~kg} / \mathrm{ha} / \mathrm{yr} \mathrm{NH}_{4} \mathrm{NO}_{3}\right)$. However, most measures of foliar chemistry were unresponsive to variations in nitrogen and water supply. Similar to my study, others have revealed a nonlinear and unpredictable response of foliar chemistry to increasing water stress (Thomas and Hodkinson 1991; Floater 1997; Shure et al. 1998).

As expected, gypsy moth larvae exhibited greater performance when fed gray birch tissue. While I found little sensitivity of foliar chemistry to changes in seedling $\mathrm{N}$ and water availability, most measures of insect performance were sensitive to these manipulations. I found evidence for larval compensatory feeding behavior (Slanksy and Wheeler 1992), where they consumed lower quality foliage at faster rates than higher quality foliage. The response of larval nutritional indices to foliage from treatments was variable and patterns were unclear. I concluded that the changes I observed in larval performance due to resource supply of host species do not impact growth rates or consumption rates in ways that would increase outbreak susceptibility in forests receiving elevated $\mathrm{N}$ deposition and variable rainfall events. It is more likely that the potential for gypsy moth outbreak will depend on factors that regulate forest species composition.

In summary, I found that elevated $\mathrm{N}$ differentially affects the growth of deciduous tree species in ways that increase their potential to experience symptoms of water stress. Although it 
was not clear in my study, others have shown that plants make physiological adjustments to compensate for increased drought sensitivity, such as changes in resource-use efficiency (Field et al. 1983; Reich et al. 1989; Wang et al. 1998). The extent to which different species are able to make these adjustments could ultimately determine their success in water-limiting, elevated $\mathrm{N}$ environments. Future studies should examine how varying water supply to seedlings grown under elevated $\mathrm{N}$ availability affects seedling survival and regeneration in the field, and the impact on changes in forest species composition. This is especially important to consider, since alterations in forest species composition could greatly affect forest susceptibility to defoliation by generalist insect herbivores, such as gypsy moth. 


\section{REFERENCES}

Bryant, J.P., F.S. Chapin III, D.R. Klein. 1983. Carbon/nutrient balance of boreal plants in relation to vertebrate herbivory. Oikos 40:357-368.

Burns, R.M. and B.H. Honkala. 1990. Silvics of North America, vol 2. Hardwoods. USDA, Washington.

DeVisser, P.H.B., W.G. Keltjens and G.R. Findenegg. 1996. Transpiration and drought resistance of Douglas-fir seedlings exposed to excess ammonium. Trees 10:301-307.

Emmett, B.A., S.A. Brittain, S. Hughes and V. Kennedy. 1995. Nitrogen additions $\left(\mathrm{NaNO}_{3}\right.$ and $\mathrm{NH}_{4} \mathrm{NO}_{3}$ ) at Aber forest, Wales: II. Response of trees and soil nitrogen transformations. For. Ecol. Manage. 71:61-73.

Field, C., J. Merino and H.A. Mooney. 1983. Compromises between water-use efficiency and nitrogen-use efficiency in five species of California evergreens. Oecologia 60:384-389.

Floater, G.J. 1997. Rainfall, nitrogen and host plant condition: consequences for the processionary caterpillar, Ochrogaster lunifer. Ecol Entomol 22:247-255.

Ibrahim, L., M.F. Proe and A.D. Cameron. 1998. Interactive effects of nitrogen and water availabilities on gas exchange and whole-plant carbon allocation in poplar. Tree Physiol. $18: 481-487$.

Liebhold, A.M., K.W. Gottschalk, RM Muzika, M.E. Montgomery, R. Young, K. O'Day and B. Kelly. 1995. Suitability of North American tree species to the gypsy moth: a summary of field and laboratory tests. USDA Forest Service general technical report NC-211. NE Forest Experiment Station, Morgantown. 
Lippert, M., K.H. Häberle, K. Steiner, H.D. Payer and K.E. Rehfuess. 1996. Interactive effects of elevated $\mathrm{CO}_{2}$ and $\mathrm{O}_{3}$ on photosynthesis and biomass production of clonal 5-year-old Norway spruce [Picea abies (L.) Karst.] under different nitrogen nutrition and irrigation treatments. Trees 10:382-392.

Osonubi, O. and W.J. Davies. 1981. Root growth and water relations in oak and birch seedlings. Oecologia 51:343-350.

Reich, P.B., M.B. Walters and T.J. Tabone. 1989. Response of Ulmus americana seedlings to varying nitrogen and water status. 2. Water and nitrogen use efficiency in photosynthesis. Tree Physiol. 5:173-184.

Shure, D.J., P.D. Mooreside and S.M. Ogle. 1998. Rainfall effects on plant-herbivore processes in an upland oak forest. Ecology 79:604-617.

Slanksy, F. Jr. and G.S. Wheeler. 1992. Caterpillars' compensatory feeding response to diluted nutrients leads to toxic allelochemical dose. Entomol exp appl 65:171-186.

Thomas, A.T. and I.D. Hodkinson. 1991. Nitrogen, water stress and the feeding efficiency of lepidopteran herbivores. J Appl Ecol 28:703-720.

Traw, M.B., R.L. Lindroth and F.A. Bazzaz. 1996. Decline in gypsy moth (Lymantria dispar) performance in an elevated $\mathrm{CO}_{2}$ atmosphere depends upon host plant species. Oecologia 108:113-120.

Van der Eerden, L.J.M. and M.G.F.J. Perez-Soba. 1992. Physiological responses of Pinus sylvestris to atmospheric ammonia. Trees 6:48-53.

Wang, J.R., C.D.B. Hawkins and T. Letchford. 1998. Photosynthesis, water and nitrogen use efficiencies of four paper birch (Betula papyrifera) populations grown under different soil moisture and nutrient regimes. For. Ecol. Manage. 112:233-244. 
White, T.C.R. 1984. The abundance of invertebrate herbivores in relation to the availability of nitrogen in stressed food plants. Oecologia 63:90-105. 
CURRICULUM VITA

\section{Teri Samantha Myers}

\section{$\underline{\text { Education }}$}

2000 PhD in Biology. Department of Biology, West Virginia University, Morgantown, WV

1995 B.S. in Botany. Department of Botany, University of Florida, Gainesville, FL

\section{Professional Experience}

1997-2000 Research Assistant, Department of Biology, West Virginia University

1995-1999 Teaching Assistant, Department of Biology, West Virginia University

1993-1995 Research Assistant, Departments of Botany and Zoology, University of Florida

\section{Courses Taught}

Principles of Biology (laboratory), West Virginia University

Ecology and Evolution (laboratory), West Virginia University

\section{$\underline{\text { Research and Teaching Awards }}$}

Eberly College of Arts and Sciences Outstanding Graduate Student (2000)

Sigma Xi Scientific Society Graduate Research Award (2000)

Earl L. Core Memorial Scholarship for the Study of Appalachian Ecology $(1997,1999)$

Outstanding Graduate Teaching Assistant in the Department of Biology (1999)

Higher Education Resouce Fund Fellowship for Teaching (1995-1999)

College of Liberal Arts and Sciences Undergraduate Research Achievement Award (1994-1995)

\section{$\underline{\text { Publications }}$}

Myers, T.S. 2000. Effects of $\mathrm{N}$ and water on growth, photosynthesis, and leaf properties of deciduous tree species with consequences for gypsy moth herbivory. PhD Dissertation.

Tamboia, T., M.L. Cipollini, and D.J. Levey. 1996. An evaluation of vertebrate seed dispersal syndromes in four species of black nightshade (Solanum sect. Solanum). Oecologia 107: 522-532. 